\title{
الثقافة التنظيمية وعلاقتها بالفاعلية الإدارية لدى قادة المدارس بمحافظة القرى من وجهة نظر المعلمين
}

\author{
عيد سعر البشيري الزهراني
}

\section{الملخص:}

هدفت الدراسة إلى عما إذا كان هناك علاقة ارتباطية بين الثقافة التنظيمبة السائدة في

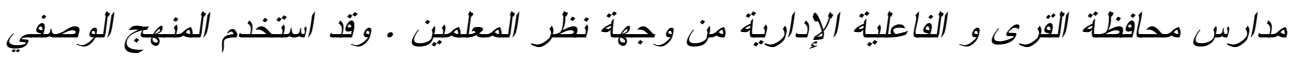

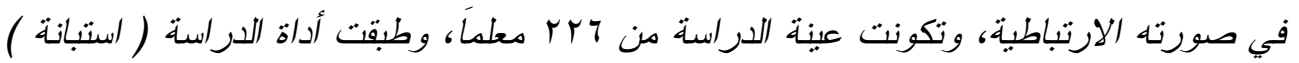
مكونه من اء فقرة موزعة على سبع مجالات ( ثقافة السياسات الإدارية التنظبيية، ثقافة

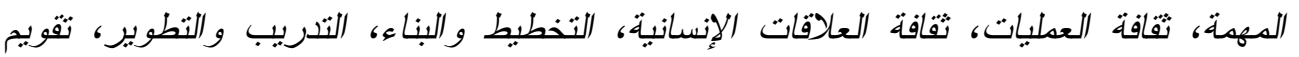

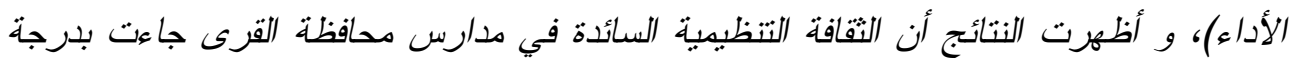

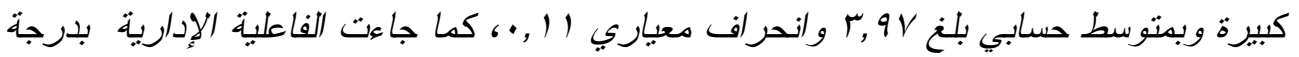

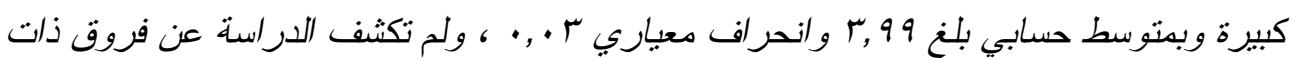

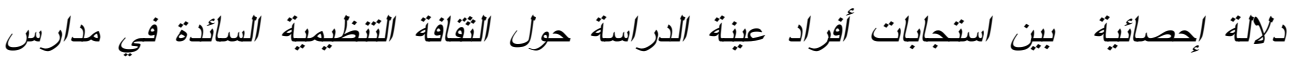

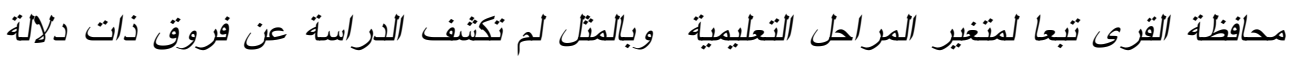

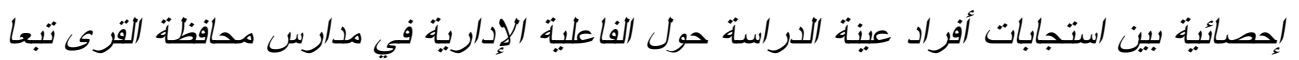

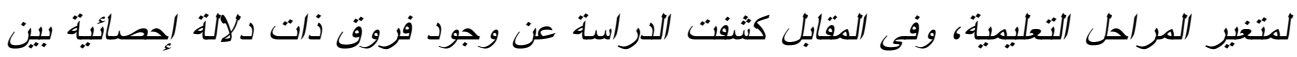
استجابات أفراد عينة الدراسة حول الثقافة التنظيمية السائدة في مدارس محافظة القرى تبعا

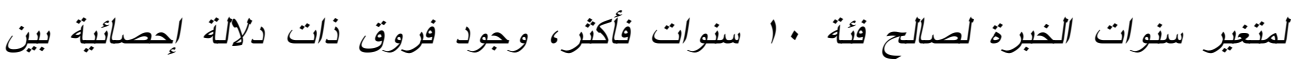

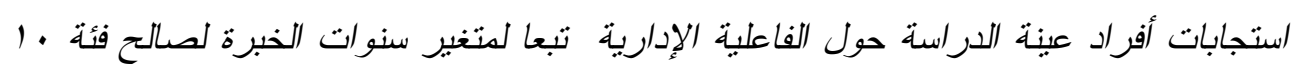

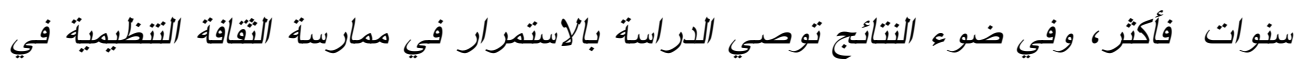

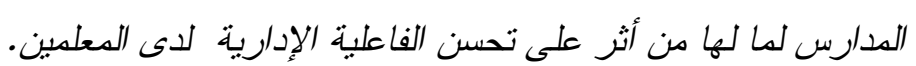

\section{Abstract}

The study aimed to uncover the correlation relationship between the degree of organizational culture practice Al-qara schools and the exercise of administrative effectiveness of teachers the researcher used. The correlation descriptive approach, the study sample consisted of (226) teachers, a questionnaire was used, consisting of (41) paragraphs divided into seven fields (Organizational management policy culture, mission culture, process 
culture, human relations culture, planning and construction, training and development, performance evaluation) the results showed that the application of organizational culture at Al-qara schools came to a great extent with an average of (3.97), the exercise of administrative efficiency came to a great extent with an average of (3.99), there were no statistically significant differences at the level of function $(\propto \leq 0.05)$ in the degree of responses of members of the study sample to the degree of application of organizational culture at Al-qara schools depending on the variable educational stages, there were no statistically significant differences at the level of function $(\alpha \leq 0.05)$ In contrast, the study showed that of responses of members of the study sample to the degree of application of administrative effectiveness at Al-qara schools depending on the variable educational stages, there were statistically significant differences at the level of function $(\alpha \leq 0.05)$ in the degree of responses of members of the study sample to the degree of application of organizational culture at Al-qara schools depending on the variable years of experience for the benefit of the 10 years and over, there were statistically significant differences at the level of the function $(\propto \leq 0.05)$ In the degree of responses of members of the study sample to the degree of application of administrative effectiveness at Alqara schools depending on the variable years of experience in favor of the 10 years and above category, According to the findings, the study recommends continuing the practice of organizational culture in schools because of their impact on improving the administrative effectiveness of teachers.

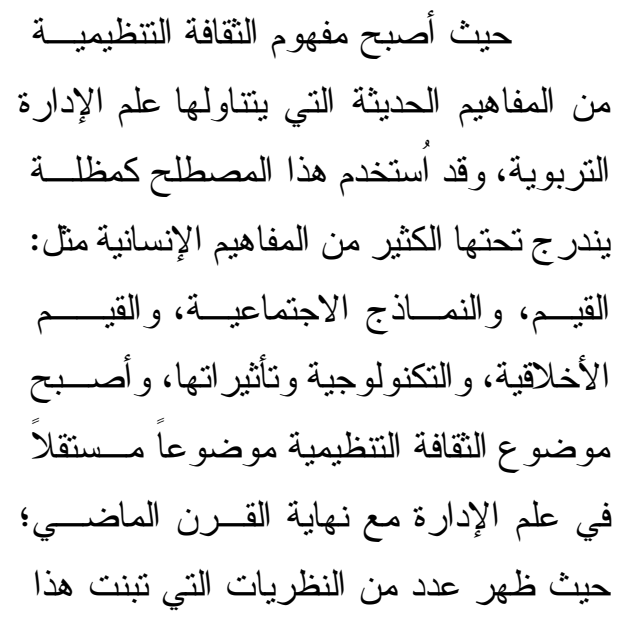




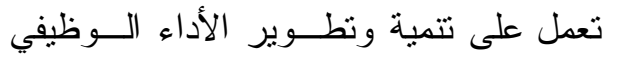

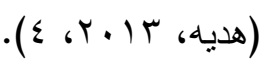

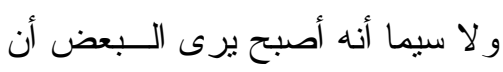

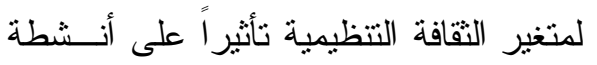

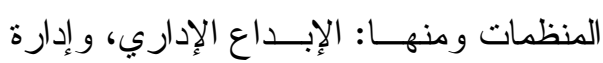
الأزمات؛ لكونه أحد السبل المهمة التي نساعد

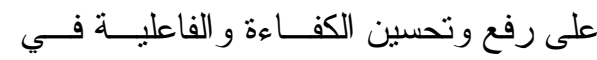
المنظمات، وحيث أن العاملين يحملون أفكارً

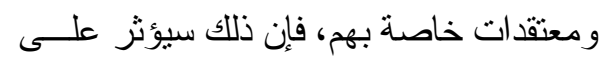
التفاعل الاجتماعي و الإبداعي و الثقافي داخل

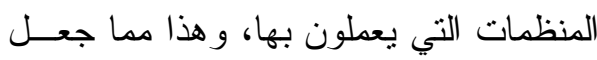

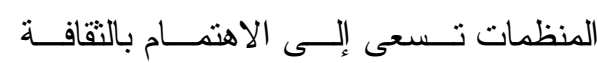

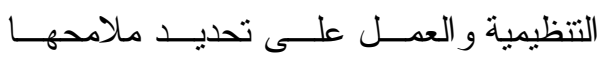
و أدوار ها في الوصول بمستوى الأداء داخل المنظمة إلى مستوى الجودة؛ الذي من خلاله

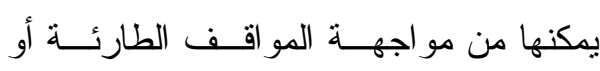

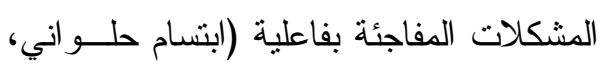

$$
\text { . ( r r. . . } 9
$$

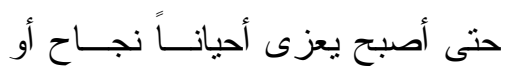

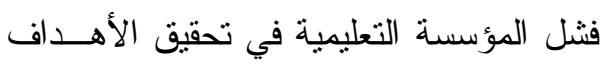
إلى كفاءة قيادتها وفعاليتها أو عدم كفاءتهــا،

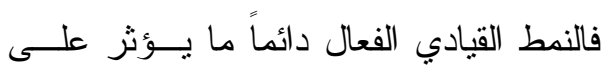

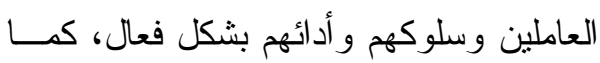

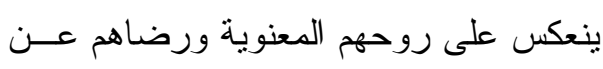
العمل وو لائهم و انتمائهم (بن حفيظ و الثنايب،

.(1) 11 . T
المفهوم، ومنها: "نظرية الثقافـــة التنظيميـــة" لــديل وكينــدي (Deal \& Kennedy)، وفحو اها أن لكل منظمة ثقافتها الخاصة، و هي تتكون من الجو انب الأساســية و الــسلوكيات

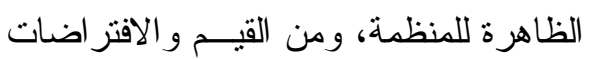

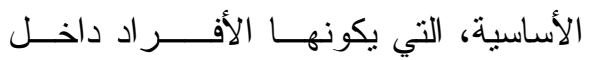
منظماتهم وبيئاتها الخارجية (ديمـــة عليــان، .00 .14 وتقوم الثقافة التتظيمية بعدة وظــائف

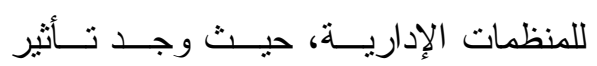
مخرجات التقافة التتظيمية سلباً أو إيجاباً على الإدي

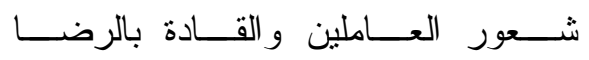
Solidarity Satisfaction

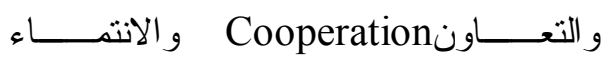
Belonging الثقافة تتصف بالاستمر ارية النسبية، وتؤثر

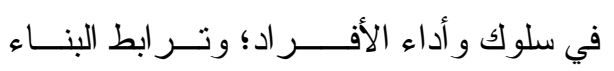
الاجتماعي للمنظمة (الركايبي، ساء ـ ب، V). حيث تترك الثقافة التنظيميــة أنــراً رئيساً على جميع المستويات و الأنشطة داخل التنظيم الإداري، وأسهمت في إيجاد المنــاخ

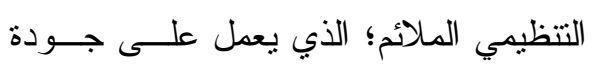
وتطوير الأداء بشكل ملائم وفعال، مما ساهم في تحقيق الأهـــداف الفرديــة و الجماعيـــة

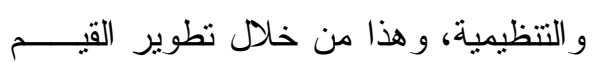
و الاتجاهات و السلوك و المعايير الحديثة التي 


\begin{tabular}{|c|c|}
\hline 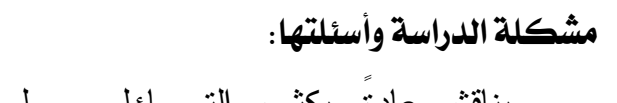 & فتميز المؤسسة التربوية ونجاحها، بدءً \\
\hline يناقش عادة ويكثـــر التـساؤل حـــول & بالمدرسة في أداء مهماتها، يتوقف إلى حــــ \\
\hline مخرجات النظام التزبوي بالمملكة العربيـــة & كبير على قدرة تفعيل إدارتها، وقدرتها على \\
\hline السعودية؛ و التي قد تُوصف فــي ظـــروف & توجيه العمليـــة التربويــة نحـــو الأهــــاف \\
\hline كثيرة بالضعف و القصور وذلك في ضو ء ما & المرسومة لها، كما قــــــــــهم التوجهــات \\
\hline أشارت إليه نتائج دراسة الغامدي (ع . . †)، & الحديثة و المرتكــز ات الأساســـية لتطـــــير \\
\hline الأمر الذي ينبغي أن يركز فيه على الاهتمام & فعالية الإدارة التزبوية بالشكل الملائم تتطلب \\
\hline بدور المدرسة في المجتمع السعودي، ومــــا & تـــوفر بيئــة تربويــة مناســبة؛ تــضبطها \\
\hline يسودها من ثقافة تتظيمية، كما يشير هديــــ & معايير وتثقافة و اضــــة المعــالم (الحــسن، \\
\hline 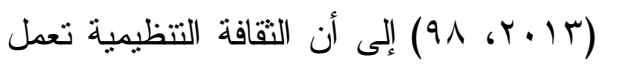 &.$(r ،$ \\
\hline على وضع تصور لسياسة المدرسة، حيـــ & ويعتبر قادة المدارس حجر الز اوية في \\
\hline فمن خلالها يعبر جميع العاملين بهـــا عـــــا & تحقيق الفاعلية الإدارية داخــل المؤســسـات \\
\hline بداخلهم من أفكار وتوجهات ومعتقدات وقيٍ & 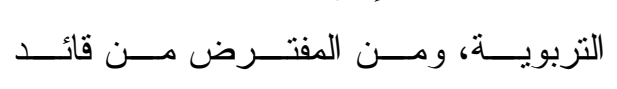 \\
\hline تم اكتسابها من تللك الثقافة، فيظهر ذلك أثزا & المدرسة- بحكــم منــصبه- تقــديم خدمــة \\
\hline و اضحاً في حل المشكلات، و التعامـلـ مـــع & تعليمية ذات جودة عاليــة، و الــسعي إلــى \\
\hline الأزمات، وتحقيق الأهــــــ بطــرق أكثـــر & تحقيق معـدلات مــن التــرابط التــسيقي \\
\hline فاعلية داخل المدرسة. & بين العاملين معه لرفــع وتحـسين جــودة \\
\hline 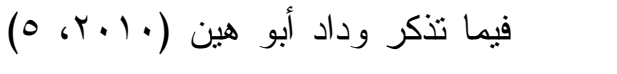 & العملية التعليمية وتطوير الأداء العام ســعياً \\
\hline أنه ينبغي على المؤسسات التعليمية التي نود & في تحقيق الأهداف التزبويــة المرســومة، \\
\hline الوصول إلى مستويات عالية مــن الإبــــاع & و هذا ما يتطلب وجود ثقافة تتظيمية ضابطة \\
\hline الإداري أن تبذل جهوداً ملحوظـــة لتــوفير & لعمل كل من القائد و العاملين معه (حسـن، \\
\hline الثقافة التتظيمية الملائمة، و المــشجعة علــى &.$(7$ ، \\
\hline الإبداع، و استثمار إمكانــات العــاملين بهـــا & وعلى ضوء هذا فإن الدر اسة الحالية \\
\hline بكفاءة لتحقيق الفاعلية المطلوبة فــي تتفـــذ & تهدف إلى تحديد مستوى التقافـــة التتظيميـــة \\
\hline هد افها. & السائدة في مدارس محافظة القرى، وعلاقتها \\
\hline ومن هذا المنطلق تشير نتائج بعــض & بدرجة الفاعلية الإدارية لدى قادة المــدارس، \\
\hline الدر اسـات كما فــي دراســة أبـــــ الجبــين & لمر المعلمين. \\
\hline
\end{tabular}


r. هل توجد فروق ذات دلالة إحـصائية

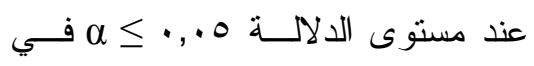
متوسطات اســتجابات أفــر اد عينـــة الار اسة حول الثقافة التتظيمية الــسائدة

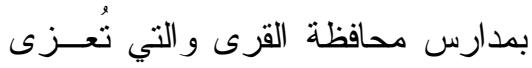

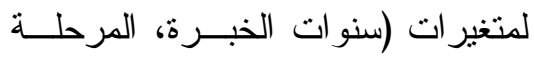
التعليمية، التخصص)؟ r. ما درجة الفاعلية الإدارية لــدى قـادة مدارس محافظة القرى من وجهة نظر المعلمين؟ ـ. هل نوجد فروق ذات دلالة إحـصائية

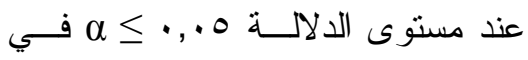

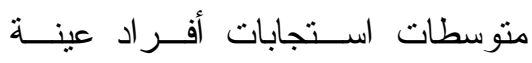
الدراسة حول الفاعلية الإدارية لدى قادة

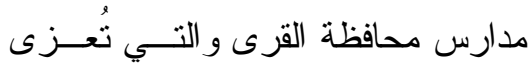
إلى متغير ات (سنوات الخبرة، المرحلة التعليمية، التخصص)؟ ـ. هل توجد علاقة ارتباطية ذات دلالـــة

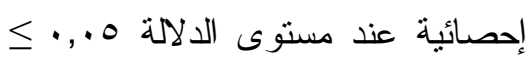

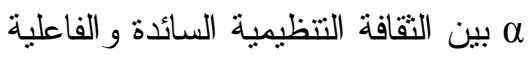
الإدارية لإى قادة المدارس بمحافظـــــة القرى من وجهة نظر المعلمين؟

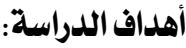

تسعى الدر اسة إلـى الكـشف عـن

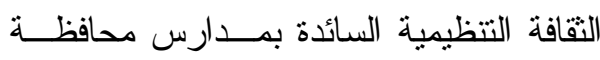
القرى، وعلاقتها بدرجة الفاعليــة الإداريـــة للدى قادة مدارس محافظة القرى من وجهـــة

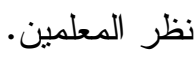

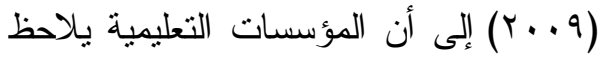

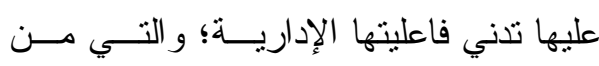

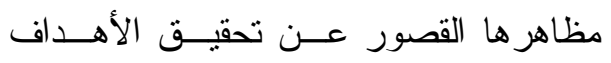
المخطط لها و المرجو تحقيقها. ويرى الباحث من خلال مشاهداته في

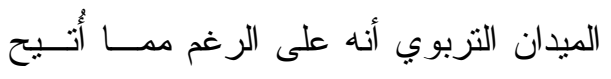
لقادة المدارس من صلاحيات كبيــرة، إلا أن توظيف هذه الصلاحيات ما زال يمثل عاملاً

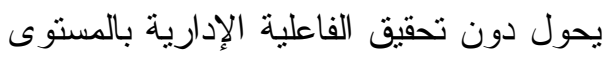

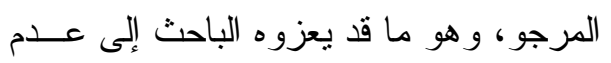

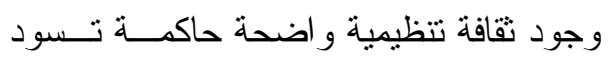
داخل هذه المؤسسات التعليمية. ومع قلة الدراسات التــي اســتهدفت تحديد مستوى الثقافة التنظيمية في مــدارس

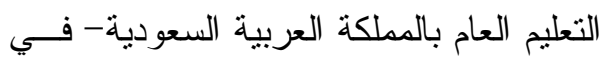

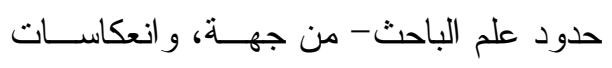

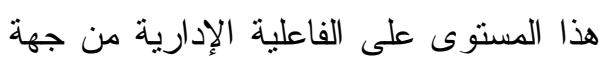

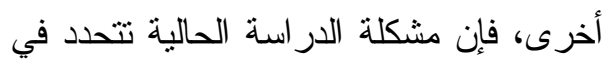

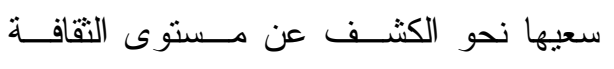

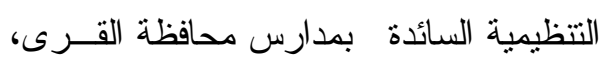

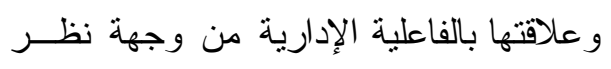
المعلمين. وفي سياق أكثر تحديداً، تـسعى الدراســة الحالية إلى الإجابة عن الأسئلة التالية: ا ـ ما درجة الثقافــة التنظيميــة الــسائدة بمدارس محافظة القرى من وجهة نظر 


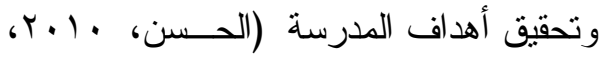

\section{. $(9$}

ويعرفهــــا الباحـــث إجر ائيــاً بأنهــــا:

الجدارة والاتقان الذي تحققه قيادات المدارس لهرس باتس

بمحافظة القرى في تفعيلها للأهداف التعليمية

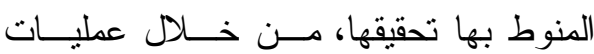

التخطيط و البناء، و التدريب و التطوير وتثقيم

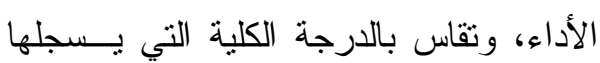

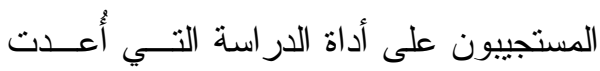

$$
\text { لهذا الغرض. }
$$

حدود الدراسة ومحدداتها:

نم تطبيق الدراسة وفق الحدود الآتية:

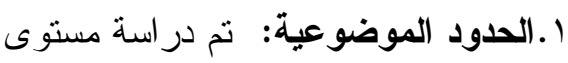

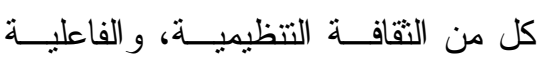

$$
\text { الإدارية. }
$$

ץ.الحدود الزماتية: تم تطبيق أداة الدراسة

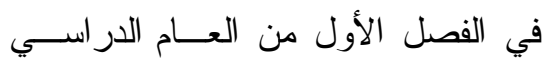

$$
\text { . } 1 \leq \varepsilon \cdot / 1 \leq r q
$$

ץ.الحدود المكاتية: تم تطبيق أداة الدر اسة

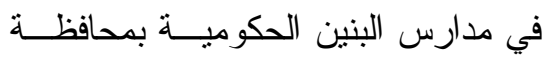

$$
\text { القرى. }
$$

ع ـالحدود البشرية: تكونت عينة الدراســـة

من معلمي مدارس التعليم العام بمحافظة

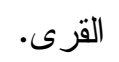

أما محددات الدراســـة، فــنم تطبيــق إجر اءات الدر اسة الحالية بمــــارس التعلــيم العام بمحافظة القرى، كما يتحدد تعميم نتائج

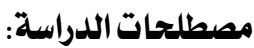

تتناول الار اسة الحالية المصطلحات الآتية:

الثقافــة التنظيميــة Organizational

\section{Culture}

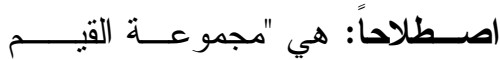

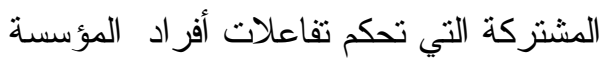

فيما بينهم ومع الأطر اف ذوي العلاقة خارج

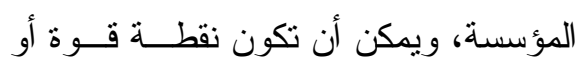

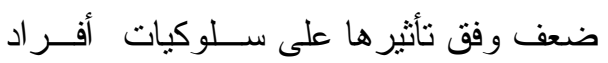

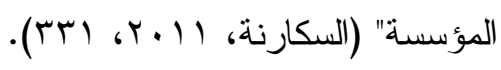

ويعرفهــــا الباحـــث إجر ائيــاً بأنهــــا:

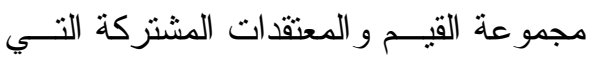
تحكم سلوك العـاملين فـــي أدائهـــم للمهـــام و العمليات و العلاقات داخل مدارس محافظــــة القرى بما يحقق الأهداف التزبوية المرسومة

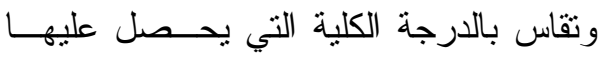

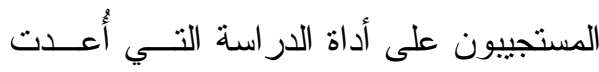
لهذا الغرض.

Administrative الفاعليــة الإداريــــة Efficiency اصطلاحاً هي: قدرة ومهارة وكفايـــة

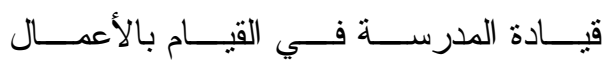
و الممارسات و الأدو ار التي ينوقع منها القيام

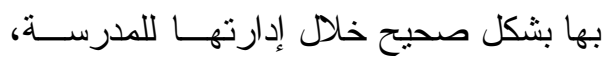

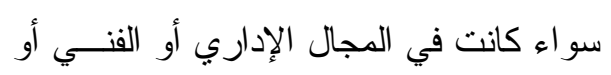
الاجتماعي بهدف إنجاح العمليــة التعليميـــة الإداء 


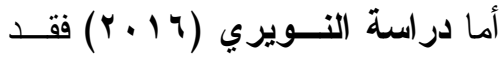

هدفت إلى التعرف على درجة تو افر أبعـاد

المنظمة المتعلمة فــي المــــارس الثانويــة

بمحافظات غزة، وعلاقتها بأنمــاط الثقافــة

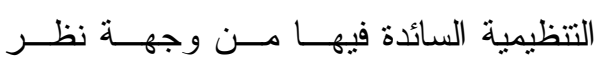

مديريها، ولتحقيق أهداف الدراسة استخدمت فئن

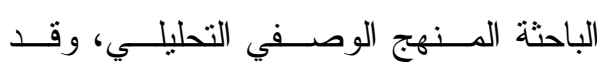

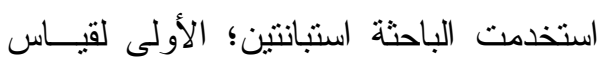

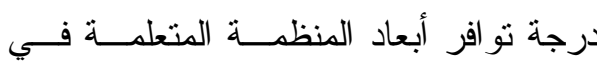

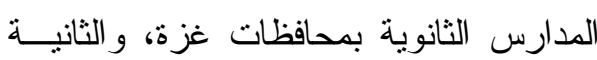

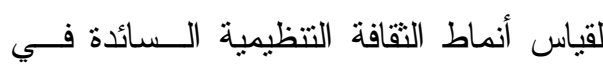
المدارس الثانوية، وقد تكونت عينة الدراســـة

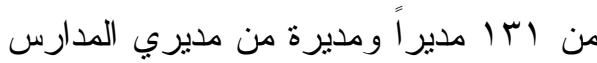

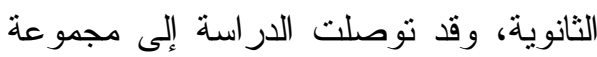

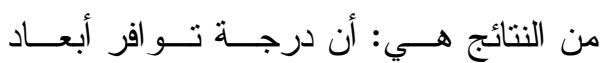

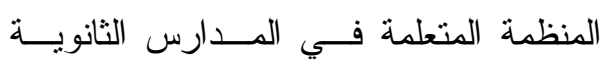
بمحافظات غزة جاءت بدرجة كبيرة بــوزن

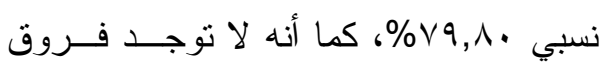
ذات دلالة إحصائية عند مسستوى (0.,. م) بين منوسطات درجات تقــدير مــديري

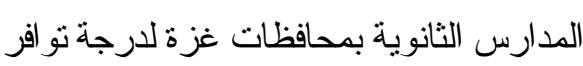

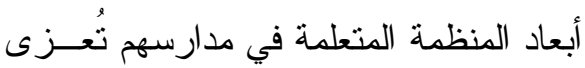

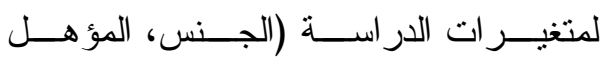

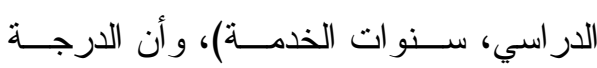

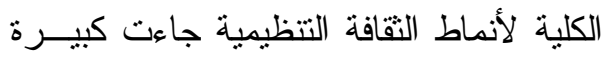

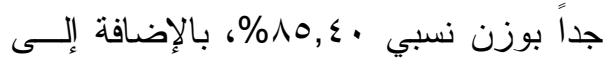

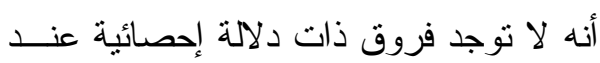

الدر اسة الحاليــة وفقــاً لخـــــائص العينـــة المستهدفة؛ و المتمنتة في معلمي التعليم العام ووفقاً لخصائص الأداة المستخدمة؛ و المتمنلة

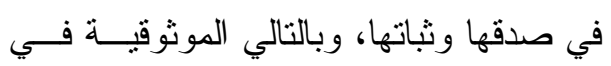
النتائج المتوفرة من خلالهها.

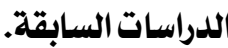

\section{المحور الأول: دراسات تناولت الثقافة التنظيمية.}

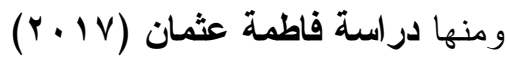

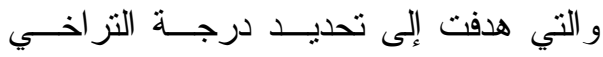
التتظيمي لدى مـــيري المــــارس الثانويـــة الخاصة في العاصمة عمان وعلاقته بالثقافة التتظيمية السائدة في مدارسهم مــن وجهــة

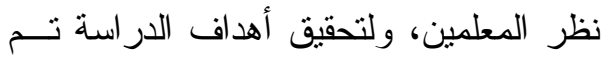

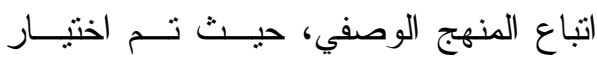

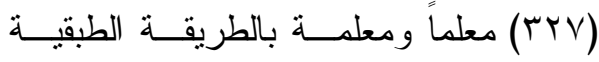

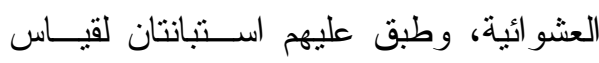
التز اخي التنظيمي و الثقافة السائدة، ونوصلت

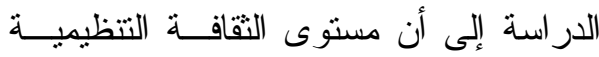

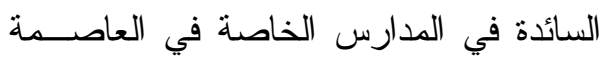

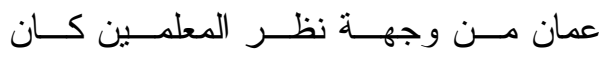
متوسطاً، إذ بلغ المتوسط الحسـسابي (ب,07)

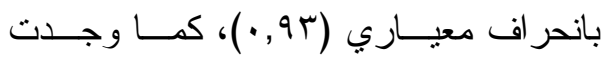

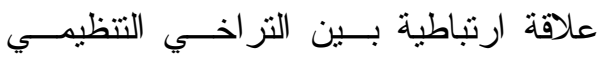
و الثقافة التنظيمية، كذلك توجد فــروق فــي لتئي الثقافة التتظيمية تعـزى لمتغيــري الخبــرة و المؤهل العلمي فيما لم تكن الفــروق دالــــة وفقاً لمتغير الجنس. 
تقدير الدرجة الكلية لمستوى الثقافة التتظيمية

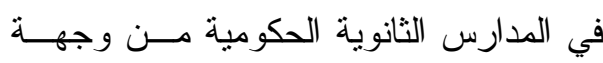
نظر مدير ات المدارس كان منخفضاً حيـــ

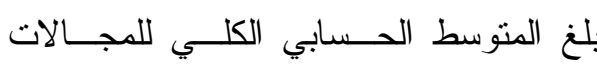

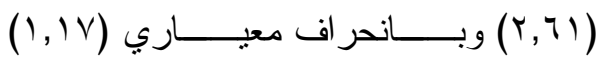
وحصول ثلاثة مجــالات علــى تقـديرات

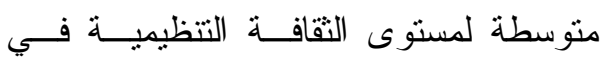

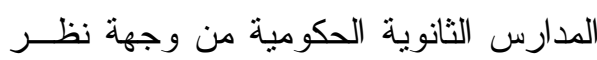

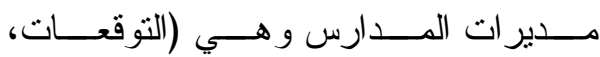

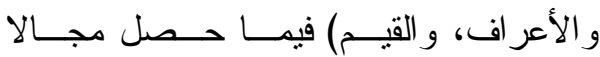
(الفلسفة و المعتقدات) على تقدير ات منخفضة لمستوى الثقافة التنظيمية. ووجــود علاقـــة ارنباطية بين مستوى الخصائص التتظيميــة

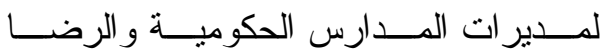
الوظيفي للمعلمات. وفي ضوء نتائج الدر اسة ولرة

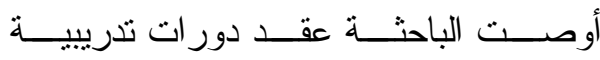
متخصصة في موضوع الثقافــة التتظيميـــة

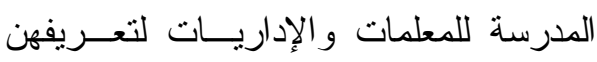
بحقوقهن وو اجبــاتهن ومسـسؤولياتهن تجـــاه وظائفهن وزميلاتهن وطالباتهن.

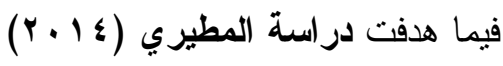
إلى تعرف أنماط الثقافة التتظيمية السائدة في مدارس التعليم العام في الهيئة الملكية بالجبيل من وجهة نظر المعلمين، وقد استخدم الباحث المنهج الوصفي التحليلي، وقد تكونت عينــة وتهنة

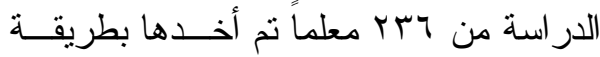

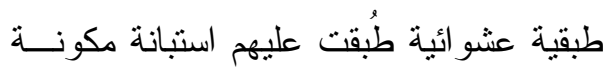

مستوى (0., , • $\alpha$ ) بين متوسطات درجات

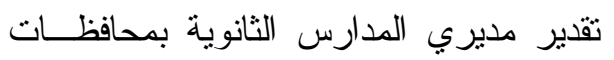

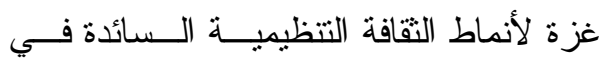
مدارسهم تُعزى لمتغير ات الدراسة (الجنس،

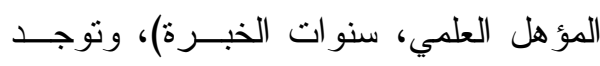
علاقة ارتباطية موجبة ذات دلالة إحـصائية

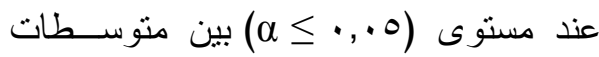

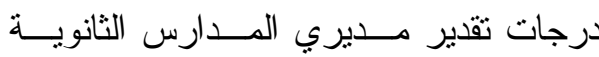
بمحافظات غزة لدرجة نو افر أبعاد المنظمـــة المتعلمة في مدارسهم وبين تقدير اتهم لأنماط الثقافة التنظيمية السائدة فيها. كما هدفت دراســة العنــود الغيــث

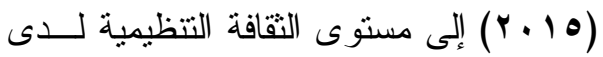
مدير ات المدارس الثانوية الحكومية بمدينـــة

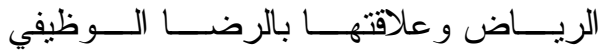
للمعلمات، استخدمت الدر اسة المنهج الوصفي من خلال نوزيع استبانة الثقافة التنظيمية لدى مدير ات المدارس الثانوية الحكومية بمدينــة الرياض، ومقياس الرضا الوظيفي للمعلمات، وقد تكونت عينة الدراسة من فئزتهـين هـــا: جميع مديرات المدارس الثانوية الحكومية في مدي لئ مدينة الرياض وبلغ عددهم (Y) مدير) مسديرة. أما الفئة الثانية فتكونت من معلمات المرحلة الثانوية في المـــارس الحكوميــة فـــي ذات

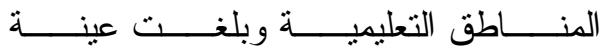

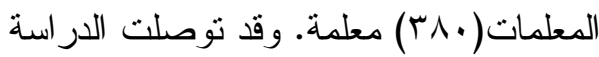
إلى النتائج الآتية: أظهرت نتائج الدراسة أن وندان 
إيجابية ذات دلالة إحصائية بين نقافة الفاعلية

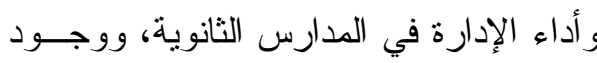
علاقة ذات دلالـــة إحــصائية بــين ثقافـــة المشاركة و أداء مديري المدارس الثانويـــة، كما توجد علاقة إيجابية بين ثقافة العلاقـات الإنسانية وأداء مديري المدارس الثانوية.

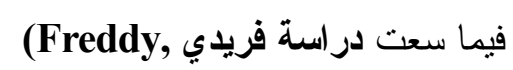

2014(إلى اكتثاف تأثنير الثقافة التتظيميـــة

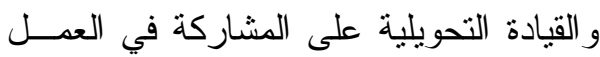

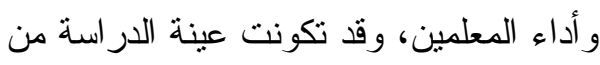

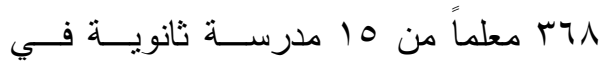

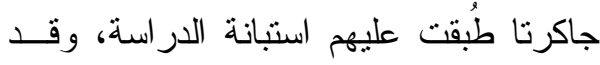

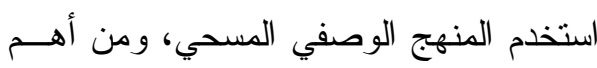

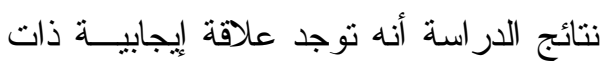
دلالة إحصائية بين ثقافة المنظمة و المشاركة

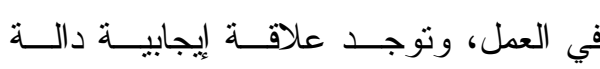
إحصائياً بين ثقافة المنظمة و أداء المعلمين. وكذلك ســـت دراســة ماتمينــاه

(Mutmainah, 2013)

التأثير ات المباشرة وغير المباثـــرة للتقافـــة التتظيمية ونمط القيادة على الالتزام التتظيمي

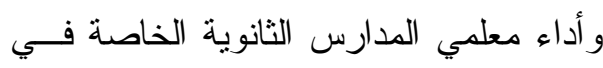
مالانق، وقد تكونت عينة الدر اسة مــن 101 من المعلمين تم أخذها بطريقة عشو ائية نسبية

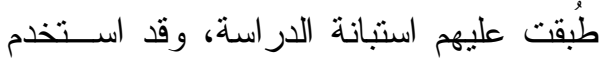

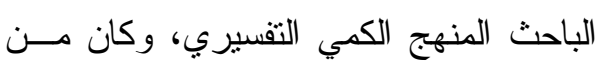
أهم نتائج الدر اسة أن أسلوب القيــادة يــؤثر
من س ف فقرة موزعة على أربعة أبعاد وهي:

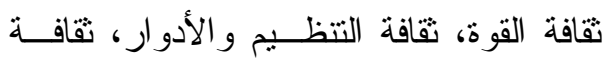

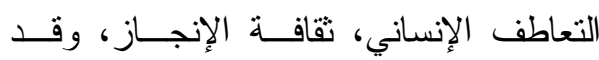
توصلت الدر اسة إلى مجمو عة من النتائج من الإنساني

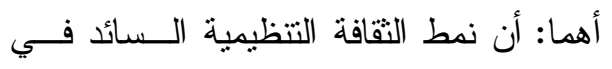

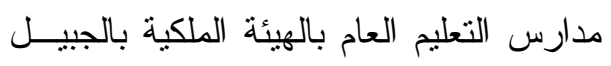
هو ثقافـــة الــنظم و الأدوار بدرجـــة عاليـــة

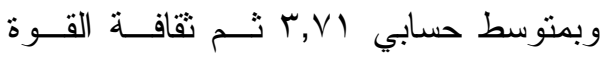

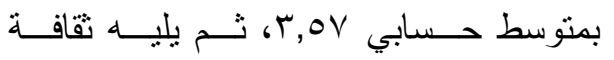

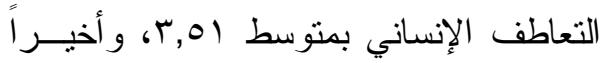

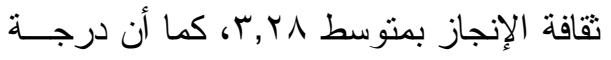
ممارسة أنماط الثقافة التنظيمية جاءت بدرجة

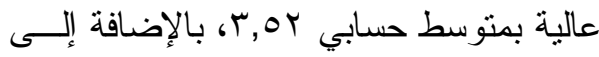

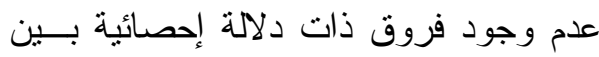

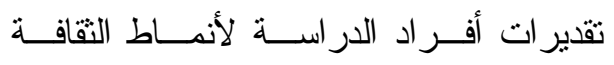

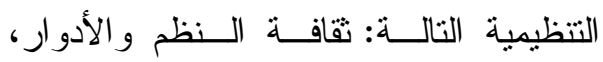
التعاطف الإنساني، الإنجاز تُعـزى لمتغيــر

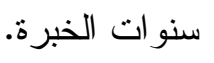
أما در اســـة إيفانجــــا و إيفجيــاجو

فقــ(Efanga \& Ifejiagwa, 2014)

هدفت إلى إيجاد العلاقة بين مكونات التقافــة

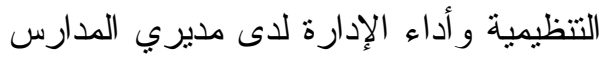
الثانوية في إكوا إييوم في نيجيريا، و اتبعــت الدر اسة المنهج الوصفي حيث نكونت عينــة

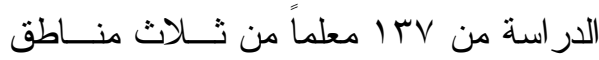
تعليمية طُبقت عليهم استبانة الدر اسة، وكـــان

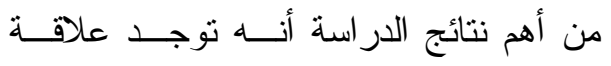


وجهة نظر مديري مدارس التعليم الابتــدائي بالعاصمة المقدسة، وقد تكونت عينة الدر اسة من 110 مديراً طُيق عليهم استبانة الدر اسة، وقد اســتخدم الباحسـث المــنهج الوصــفي

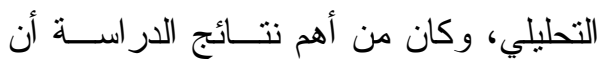

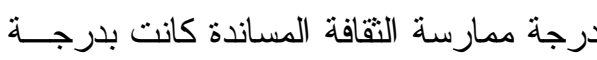
كبيرة جداً من وجهة نظر مديري المــدارس

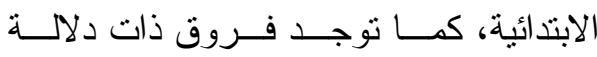
إحصائية بين منوسطات اســتجابات عينــة الهـة الدراسة حول بُعد الثقافة المساندة وفقاً لمتغير لئن المؤهل العلمي لصالح در اسات عليا. المحور الثاني: دراسات تناولت الفاعلية الإدارية.

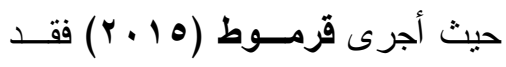
هدفت إلى الكثف عن درجة ممارسة الجودة

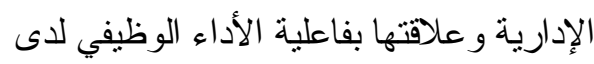

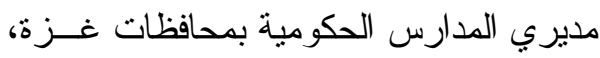
وقد تكون مجتمع الدر اسة من جميع معلمـي لئي

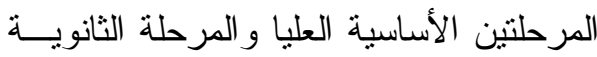
بمحافظات غزة وهي كالتنالي: (شمال غـزةة، غرب غزة، شرق غزة، الوسطى، خانيونس،

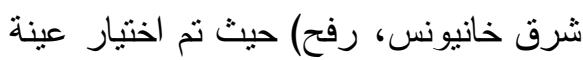
عشوائية عنقودية عددها OVN من مجتمــع

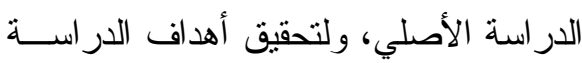
استخدم الباحث المنهج الوصفي التحليلي، ونم

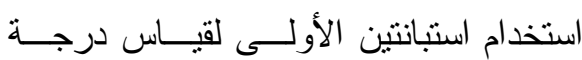

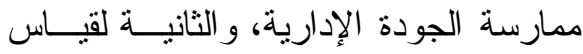

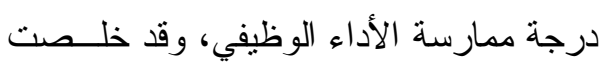

تأثنيراً مباشر اً وبشكل كبير و إيجابي في ثقافة المؤسسة، وأن الثقافة التتظيمية تؤنز تــأثنير أ

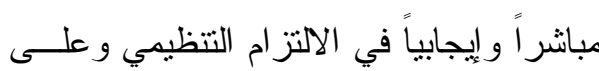

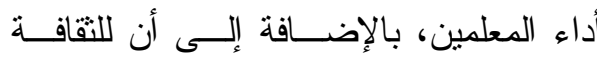

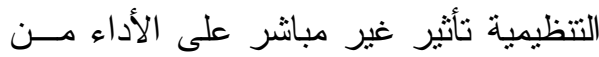
خلال الالتزام التتظيمي للمعلمين.

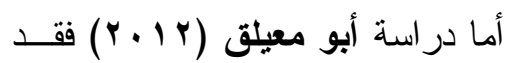
هدفت إلى الكثف عن علاقة الثقافة التنظيمية

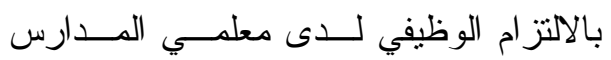

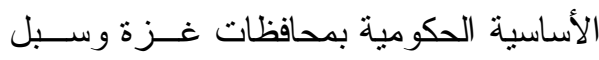
تطوير ها، وقد تكونت عينة الدراســة مــن

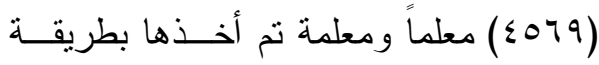

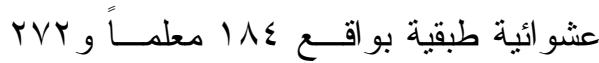
معلمة حيث طبق عليهم استبانة الدر اسة، وقد استخدمت الباحثة المنهج الوصفي التحليلـي،

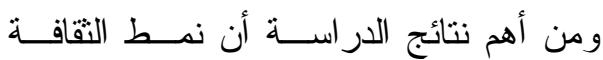

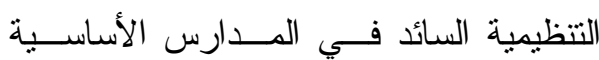
الحكومية بمحافظات غزة هو ثقافة العلاقات

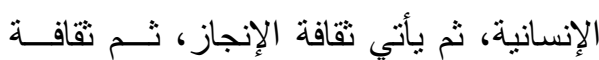

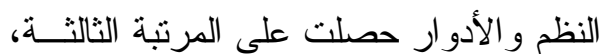

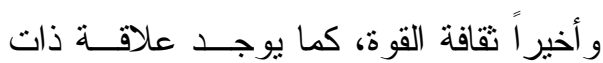

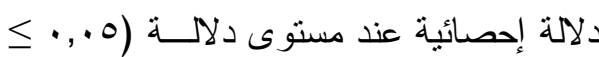
a) بين مستوى الالنز ام الوظيفي ونمط القافة

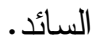

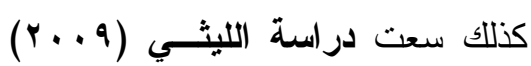
إلى الكثنف عن الثقافــة التنظيميــة لمــدير المدرسة ودور ها في الإبـــداع الإداري مــن 
محافظات الضفة الغربية مــن وجهـــة نظـــر

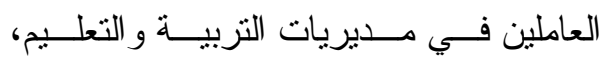

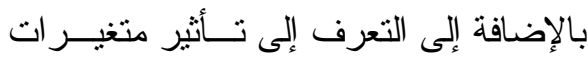
الجنس، و المؤهل العلمي و الخبرة الإداريـــة

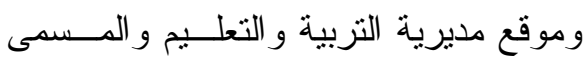

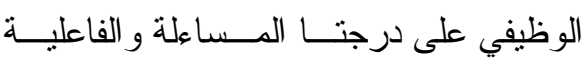
الإدارية التزبوية لـــى مــديري المـــدارس الحكومية الثانوية ومدير اتها في محافظــات الاتدية الضفة الغربية من وجهة نظر العاملين فـي

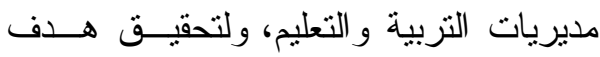

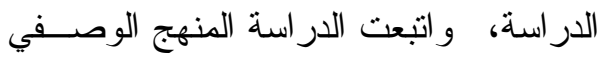

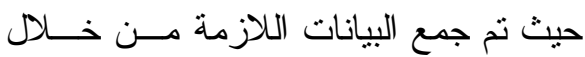
استبانة نم التأكد من صدقها وثباتها وبعد أن تم تطبيقها على عينة طبقية عـش ائية مق مـدار ها

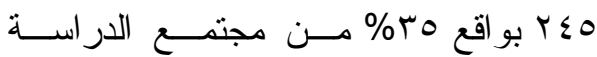
المكون من جميع العاملين في أقـسام الإدارة المدرسية، و الرقابة الإدارية و المالية، و التعليم العام، و الإثر اف التربوي، وشؤون الموظفين في مديريات التربية و التعليم في محافظــات

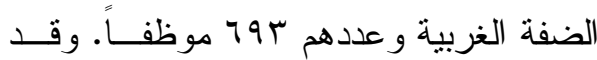

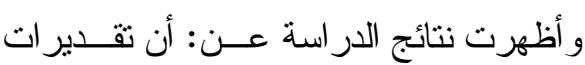
أفر اد عينة الدر اسة لدرجة المساعلة الإدارية

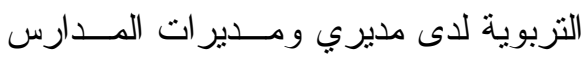
الحكومية الثانوية جاءت مرتفعة بشكل عام،

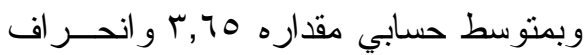

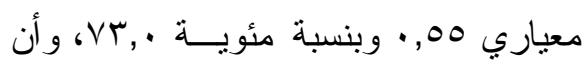

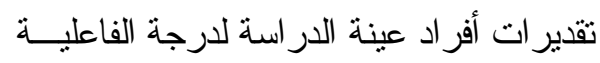

الدر اسة إلى مجموعة مــن النتــائج، حيــث

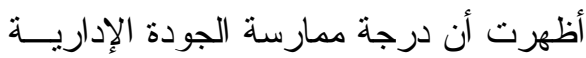
لدى مديري المدارس الحكومية بمحافظــات غزة من وجهة نظر معلميهح كبيرة، ويقع عند

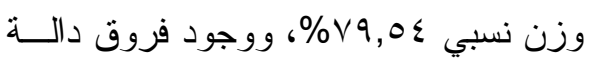
إحصائيا عند مستوى (0. ب,

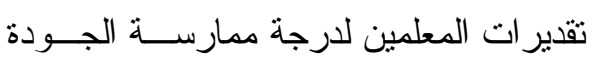
الإدارية لدى مديري المــدارس الحكوميــة

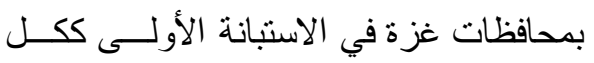
تُعزى إلى كـلـل مــن (الجــنس، المرحلـــة التعليمية)، لا توجد فروق دالة إحصائيا عند

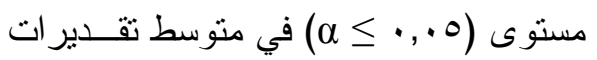
المعلمين لارجة ممارسة الجودة الإدارية لدى لدى لهن مديري المدارس الحكومية بمحافظات غزة في لهي

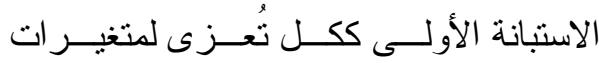

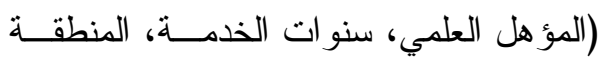
التعلمية)، و أن درجة فاعلية الأداء الــــوظيفي

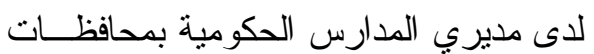
غزة من وجهة نظر معلميهم كانت كبيرة، كما توجد علاقة ارتباطية موجبة وقويــة دالـــة إحصائياً عند مستوى دلالة (0. درجة ممارسة الجودة الإدارية ودرجة فاعلية الأداء الوظيفي لدى أفر اد عينة الار اسة.

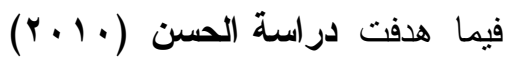
إلىى التعرف على درجتا المساءلة و الفاعليـــة الإدارية التزبوية و العلاقة بينهما لدى مديري

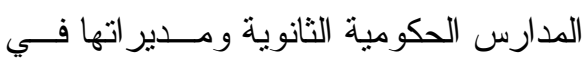


مدارس وكالة الغوث الدولية بغزة من وجهة نظر المشرفين، وتكونت عينة الدراسة مــن

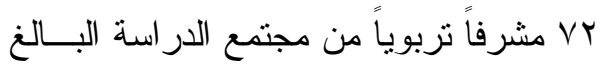

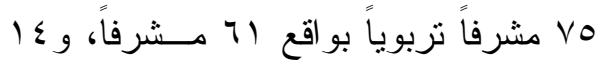

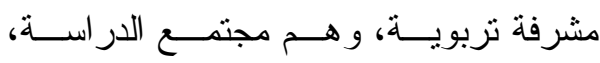
واستخدمت الباحثة المنهج الوصفي التحليلي من خلال تطبيق الدر اسة لجمع المعلومسـات

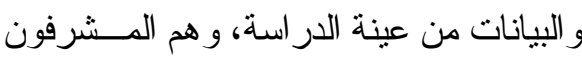
التربويون العاملون في وكالة الغوث الدولية بغزة، وتكونت أداة الدر اسة من استبانة تكونت

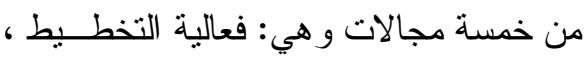

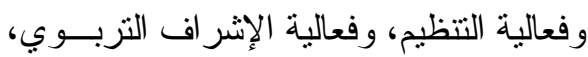
وفعالية العلاقة مع المجتمع المحلي، وتوصلت وفعالته

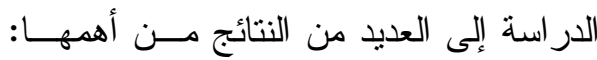

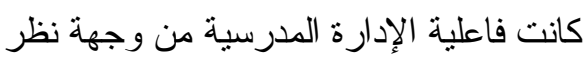
المشرفين التزبويين متوسطة من حيث الوسط الإدة الحسابي و التقل النسبي، لا يوجد فروق ذات دلالة إحصائية عند مستوى الدلالة (0.,.

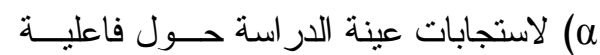

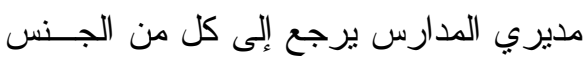
و المؤهل وخبرة المشرفين التربويين. وفي سياق منصل أجــرى العـسيلي

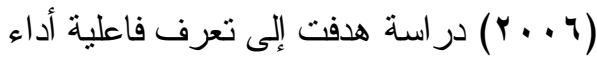

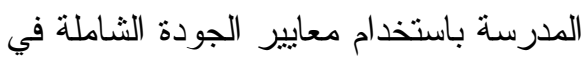
مدينة الخليل، ودرجة تقدير مديري ومعلمــي بالئي المدارس حول فاعلية أداء المدرسة باستخدام

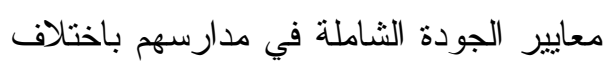

الإدارية التربوية لــدى مــديري ومـــدير ات

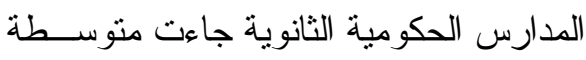

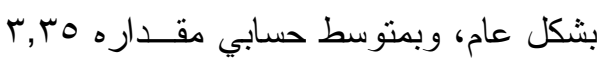

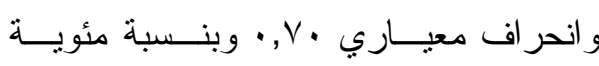
• •

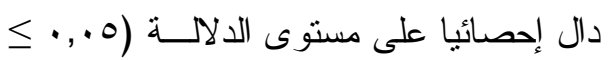

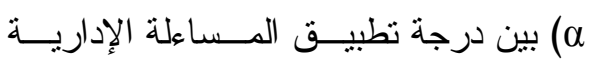

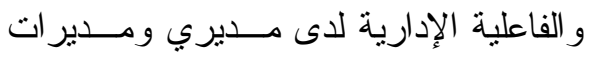
المدارس الحكومية الثانوية.

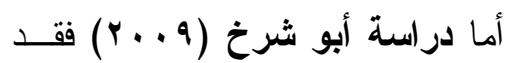
هدفت إلى التعرف على فاعلية أداء مــديري

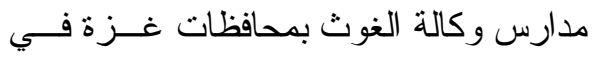
ضوء التكنولوجيا الإدارية المعاصرة وســبل ونبل

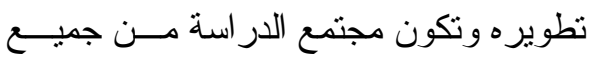
مديري مدارس وكالة الغوث بمحافظات غزة

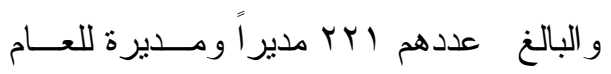

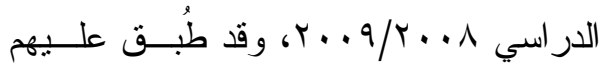
استبانة الدراسة، وقد استخدم الباحث المنهج الوصفي التحليلي لمناسبته لمنّل هذا النوع من لن

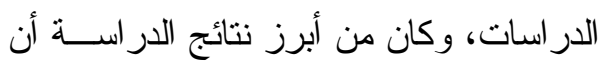

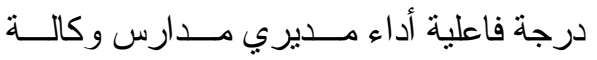
الغوث الدولية في ضوء التكنولوجيا الإدارية كانت متوفرة بدرجة جيدة، حيث كانت الدرجة

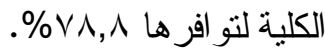

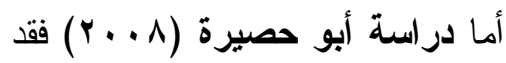
هدفت إلى معرفة فاعلية مدير المدرسة فـي ضوء معايير تطبيق الجــودة الـشـاملة فــي مئي 
لمناسب في المــدارس و المطالــب الهامـــة

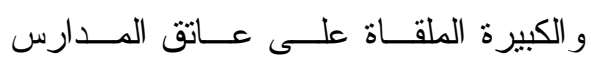

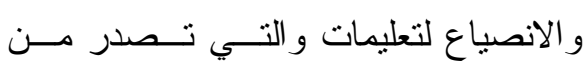

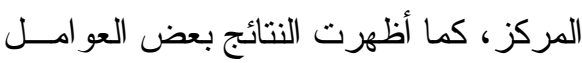
التي تؤدي الى الفاعلية كأهمية الاتصسال الفعال

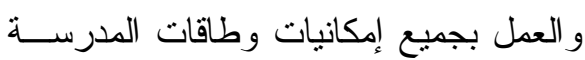

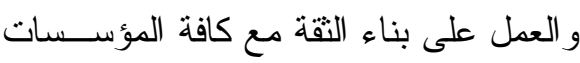
التي لها علاقة بالمدارس و العمل على كسب باء قاعدة أكبر من الخبرة.

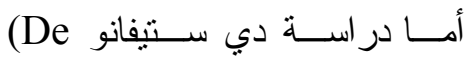

فقد هدفت إلى تحديــ Stefano, 2003)

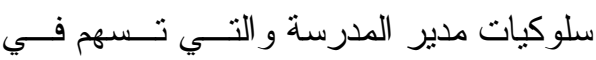
تحقيق الفاعلية المدرسية في المدارس الثانوية العامة في و لاية ســانتا فــي بــروفنس فــي الأرجنتين، و اتبعت الدر اسة المنهج الوصفي لتهي حيث نم استخدام أسلوب الملاحظة و المقابلة

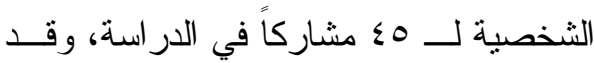
أظهرت نتائج الدر اسة أن أسلوب قيادة المدير المدرسي يعد مفتاح فاعلية المدرسة فضلا عن سلوك الانضباط الذي يظهره مدير المدرسة

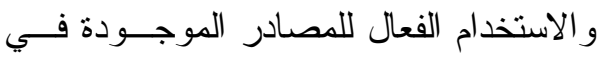
المدرسة وبالإضافة إلى بناء العلاقات الطيبة

$$
\text { مع المجتمع المحلي. }
$$

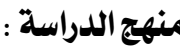

استخدم الباحث في هذه الدراسة المنهج

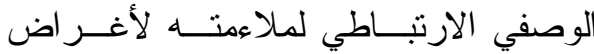

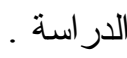

متغير ات الدر اسة. و اتبعت الدر اسة المــنهج ro. الوصفي حيث تكونت عينة الدر اسة من بهن مديراً ومعلماً من المدارس الثانوية في مدينة

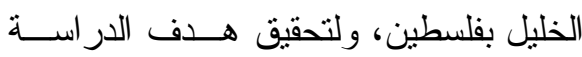

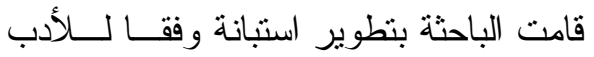
التزبوي، وقد جرى التحقق من صدق الأداة وثباتها. توصلت الدر اسة الى النتائج الآتيــة: أن منوسط تقدير درجة فاعلية أداء المدرسة توهة باستخدام معايير الجودة الثناملة فــــي مدينـــة

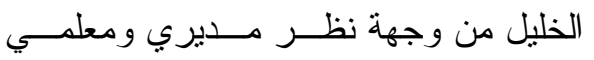

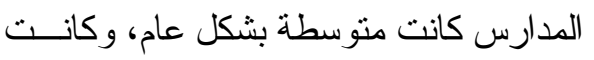
مرتفعة في مجال التخطيط الاستر اتيجي، بينما كانت منخفضة في مجال العلاقة بين المدرسة

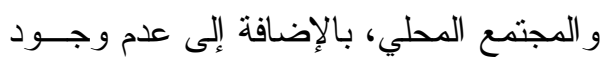

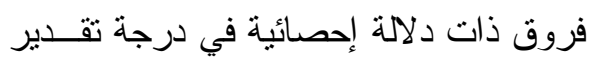

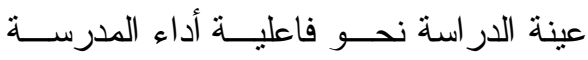
باستخدام معــايير الجــودة بــاختلاف فئسـة المستجيب و الجنس، وسنو ات الخبرة.

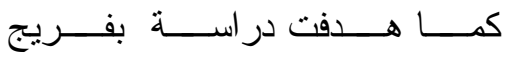

(Beverage, 2003)

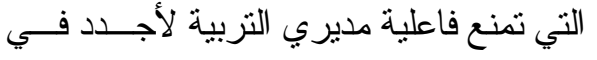
و لاية فرجينيا ."وقد استخدمت الدر سة المنهج النوعي و الكمي في البحث على عينة مقدارها

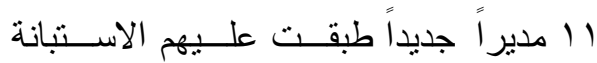

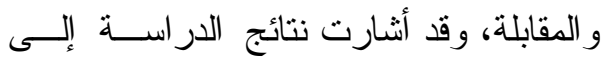

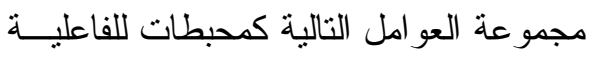
في المدارس و هي: الوضــــع المــالي غيـــر 
بـ بـ معلماً بمر احل التعليم العـام الـثنلاث،

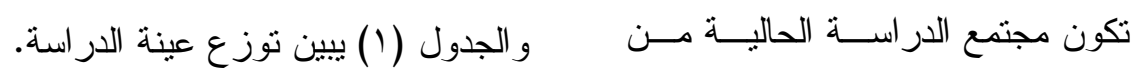

جميع معلمي مدارس محافظة القرى للعـام

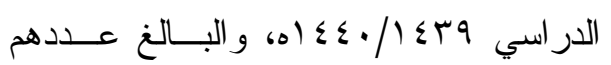

جدول (1)

توزع معلمي مدارس محافظة القرى حسب المرحلة التعليمية

\begin{tabular}{|c|c|c|c|}
\hline \multicolumn{2}{|c|}{ إحصائيات المعلمين } & \multirow{2}{*}{ عدد المدارس } & \multirow{2}{*}{ المرحلة التعليمية } \\
\hline النسبة & العدد العد & & \\
\hline$\% \circ 4$, r० & $r .7$ & rT & الابتدائية \\
\hline \%rr,q & 几. & 9 & المنوسطة \\
\hline$\% \backslash 9, \vee \backslash$ & $1 . v$ & 0 & الثانوية \\
\hline$\% 1 \ldots$ & $0 \leqslant r$ & $\varepsilon$. & المجموع \\
\hline
\end{tabular}

عينة اسنطلاعية تبلغ ( r r ) معلم وتوزيع

عينة الدراسة :

تكونت عينة الدراسة ( TYY ) معلماً أداة الدراسة عليهم

من معلمي مدارس محافظة القرى، ثم اختيار

جدول(r)

توزيع أفراد عينة الدراسة تبعا لمتغير اتها

\begin{tabular}{|c|c|c|c|}
\hline النسبة المئوية & العدد & الفئات & المتغير ات \\
\hline$\% \quad 07,19$ & IrV & ابتدائي & \multirow{4}{*}{ التعليمية المر احل } \\
\hline$\%$ \% r,^q & $0 \leqslant$ & متوسط & \\
\hline$\% 19,91$ & $\leqslant 0$ & ثانوي & \\
\hline$\% 1 \ldots$ & TrT & المجموع & \\
\hline$\% \leq \varepsilon, r \leq$ & $1 \ldots$ & اقل من · ـ سنو ات & \multirow{3}{*}{ سنوات الخبرة } \\
\hline$\%$ ००, v० & MT & عشر سنو ات فأكثر & \\
\hline$\% 1 \ldots$ & TrT & المجموع & \\
\hline \% Tד,rV & 10. & علوم إنسانية & \multirow{3}{*}{ التخصص } \\
\hline \% \% & $V_{7}$ & علوم طبيعية & \\
\hline$\% 1 \ldots$ & TrT & المجموع & \\
\hline
\end{tabular}

r. ₹ 


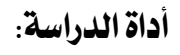

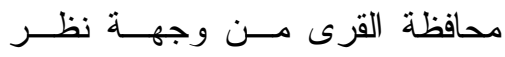

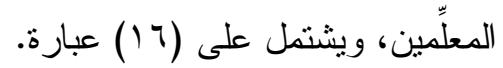

بناءً على طبيعـــة البيانــات، و وعلى لـى

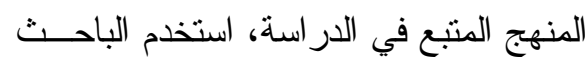

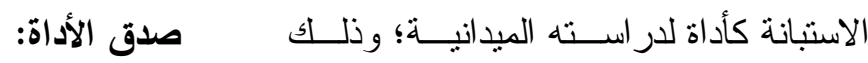

صدق أداة الدر اسة يعني التأكّد مــن

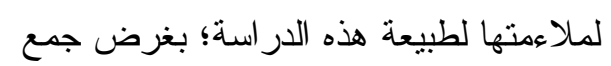

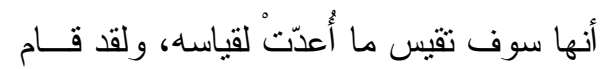

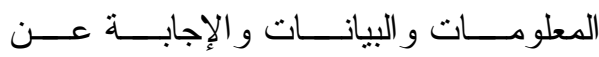

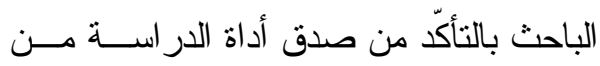

النساؤلات. وقد قام الباحث بمر اجعة أدبيات

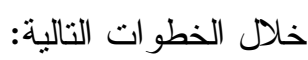

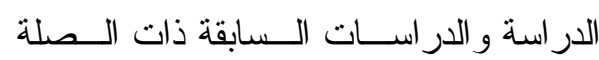

صدق المحكمين ( الصدق الظاهري ):

بموضو ع الدر اسة، حيث تمّ تصميم اسـنتبانة

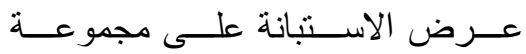

لتحقيق هدف الدر اسة، وقد تضمّنت الاستبانة

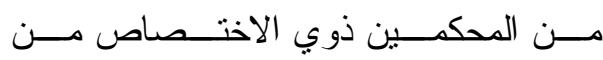

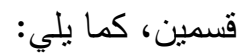

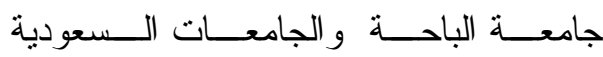

القسم الأول من أداة الدراســـة: "البياتــات

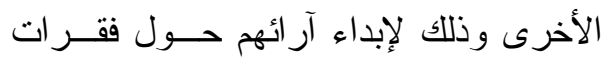

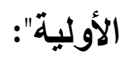

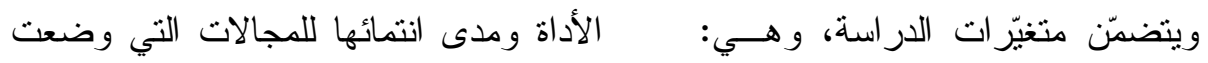

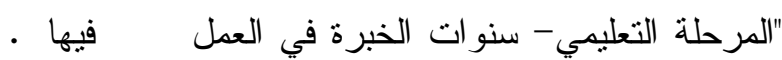

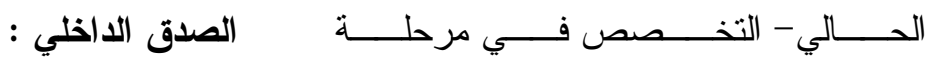

صدق البناء الداخلي للفقرات ومجالاتها

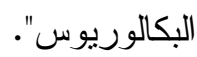

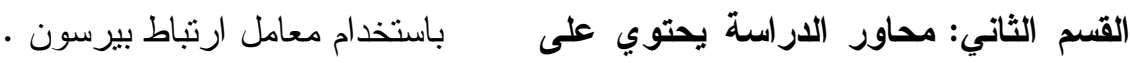

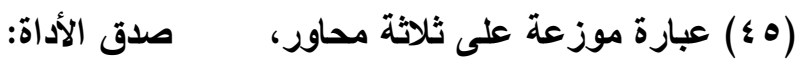

تم التحقق من صدق الأداة وفق الآتي:

وذلك كما يلي:

أ- الصدق الظاهري( صدق المحكمين) :

أ. المحور الأول الذي يقيس درجة الثقافة

وقد نم التحقق من صدق الاستبانة عن

التتظيمية السائدة بمدارس محافظــــة

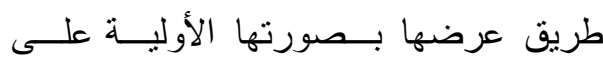

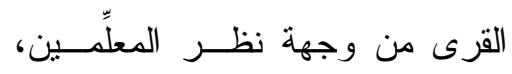

مجموعة من المحكمين، من أعــضاء هيأسـة

ويشتمل على (ro) عبارة.

التذريس في الجامعات السعودية، و الجامعات

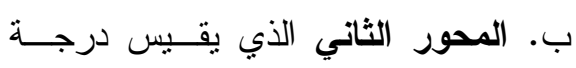

العربية، من ذوي الخبرة و الاختصاص في

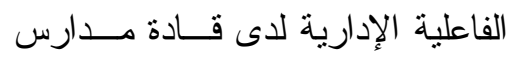

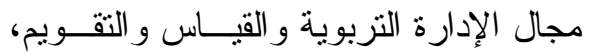




\section{جدول(؛) المجالات وارقام الفقرات التابعة}

لمحور الفاعلية الإدارية

\begin{tabular}{|c|c|c|}
\hline ارقام الفقرات & المجالات & الرقم \\
\hline 。 & التخطبط و البناء & 1 \\
\hline 0 & التدريب و التطوير & $r$ \\
\hline 1 & تقويم الأداء & r \\
\hline 17 & العدد الكلي & \\
\hline
\end{tabular}

ب - صدق البناء الداخلي:

تم حساب صدق البناء الداخلي لفقرات

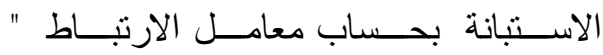

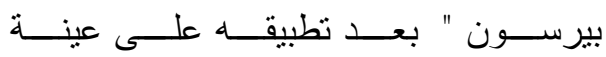

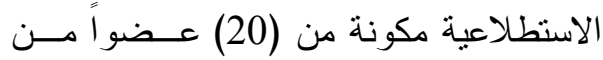

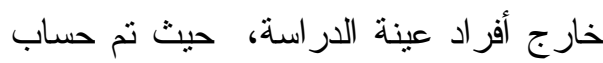

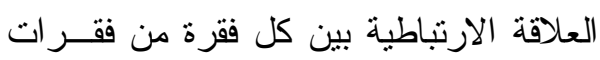

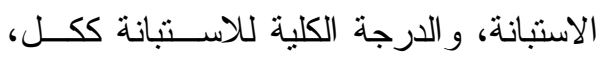

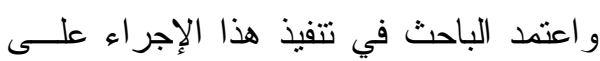

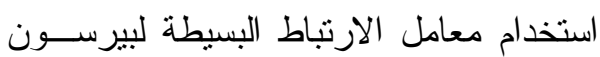
كما في الجدول(0) الآتي

جدول (0)

معاملات ارتباط كل فقرة من فقرات مقياس الثقافة التنظيمية مع المجال الأي تتنمي اليه

\begin{tabular}{|c|c|c|c|c|c|c|c|}
\hline \multicolumn{2}{|c|}{ ثُقافة العلاقات الإنسانية } & \multicolumn{2}{|c|}{ ثُقافة العمليات } & \multicolumn{2}{|c|}{ ثقافة المهمة } & \multicolumn{2}{|c|}{ ثقافة السياسات الإدارية التنظيمية } \\
\hline معامل الارتباط & م & معامل الارتباط & م & معامل الارتباط & م & معامل الارتباط & م \\
\hline$* ., 01$ & 1 & **, $\wedge Y$ & 1 & $*, 91$ & 1 & $*, \wedge\rceil$ & 1 \\
\hline$*, V V$ & $r$ & $*, \wedge 0$ & 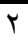 & $*, \wedge$. & $r$ & $*, 90$ & $r$ \\
\hline$*, \vee \vee q$ & $r$ & $*, \vee \vee \neg$ & $\mu$ & $*, 7 \leq$ & $\mu$ & $*, \wedge\rceil$ & $r$ \\
\hline$*, \wedge 1$ & $\varepsilon$ & $*, 7$. & $\varepsilon$ & $*, 91$ & $\varepsilon$ & $*, \wedge \vee$ & $\varepsilon$ \\
\hline$*, \vee \wedge$ & 0 & $*, 97$ & 0 & $*, 9 r$ & 0 & $*, Y \vee$ & 0 \\
\hline & & $*, V V$ & 7 & $*, \wedge 9$ & 7 & $*, \wedge 0$ & 7 \\
\hline & & & & & & $*, V Y$ & V \\
\hline & & & & & & $*, 9$. & $\Lambda$ \\
\hline
\end{tabular}

قيمة "ر" الجدولية عند مستوي ه ., .
و عددهم (22) محكما، ملحق (1)، لإبـــداء

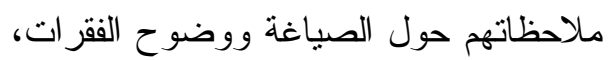
ومدى مناسبتها لغرض الدر اســـة و انتمائهــــا

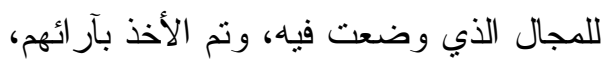
و الجدول(r) يوضح المجالات و أرقام

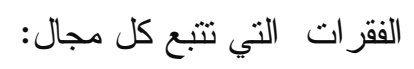
جدول(r) المجالات وارقام الفقرات التابعة لمحور الثقافة التنظيمية

\begin{tabular}{|c|c|c|}
\hline الفقر ات & المجالات & الرقم \\
\hline$\wedge$ & ثقافة السياسات الإدارية & 1 \\
\hline 7 & ثقافة المهمة & $r$ \\
\hline 7 & ثقافة العمليات & $r$ \\
\hline 0 & ثقافة العلاقات الإنسانية & $\varepsilon$ \\
\hline ro & العدد الكلي & \\
\hline
\end{tabular}


ذات علاقة ارتباطيه دالة إحصائياً بالمجال

تشير النتائج الواردة في الجدول

أعلاه أن جميع قيم معاملات الارتباط الذي تنتمي إليه .

كما نم حساب معامل ارتباط كل فقرة

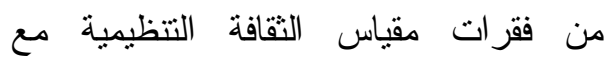

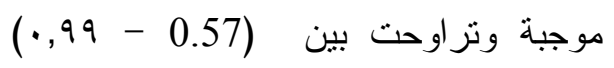

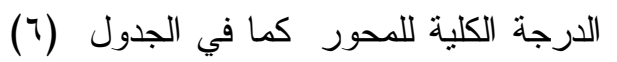

وجميعها ذات دلالة إحصائية عند مستوى هوريك

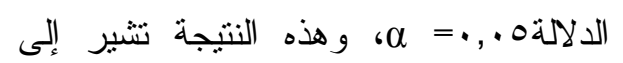

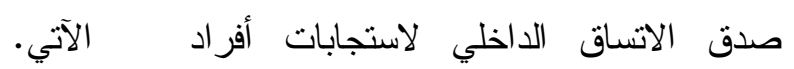

العينة الاستطلاعية على الأداة، وأن الفقرات الات التات

جدول( )

معامل ارتباط كل فقرة من فقر ات مقياس الثقافة التنظيمية مع الارجة الكلية للمحور

\begin{tabular}{|c|c|c|c|c|c|c|c|}
\hline \multicolumn{2}{|c|}{ ثقافة العلاقات الإسساتية } & \multicolumn{2}{|c|}{ ثقافة العمليات } & \multicolumn{2}{|c|}{ ثقافة المهمة } & \multicolumn{2}{|c|}{ ثقافة السياسات الإدارية } \\
\hline معامل الارتباط & م & معامل الارتباط & 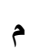 & معامل الارتباط & 5 & معامل الارتباط & م \\
\hline $0.71 *$ & 1 & $*, \wedge r$ & 1 & $*, \wedge \varepsilon$ & 1 & $*, 77$ & 1 \\
\hline $0.76^{*}$ & r & $*, \wedge 0$ & r & $*, V \Gamma$ & r & $*, 9 \leq$ & r \\
\hline $0.89 *$ & r & $*, \vee \vee 7$ & r & $*, 01$ & r & $*, T V$ & r \\
\hline $0.58 *$ & $\varepsilon$ & $*, 7$. & $\varepsilon$ & $*, \wedge \varepsilon$ & $\varepsilon$ & $*, \wedge \varepsilon$ & $\varepsilon$ \\
\hline $0.61 *$ & 0 & $*, 97$ & 0 & $*, 97$ & 0 & $*, 77$ & 0 \\
\hline & & $*, V \vee$ & 7 & $*, 94$ & 7 & $*, V$. & 7 \\
\hline & & & & & & $*, V Y$ & v \\
\hline & & & & & & $*, \wedge 0$ & $\wedge$ \\
\hline
\end{tabular}

قيمة "ر" الجدولية عند مستوي 0 .,.

ارتباط بين كل فقرة من فقر ات مقياس النقافة

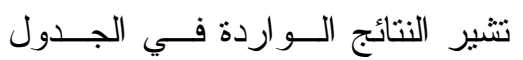

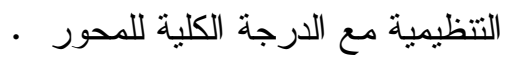

( ) ( ) أعلاه أن جميع قيم معاملات الارتباط

كما تم حساب معامل ارتباط كل مجال

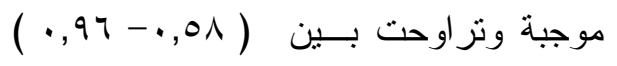

من المجالات بالدرجة الكلية لمقياس الثقافـــة

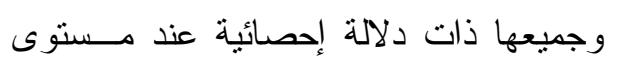

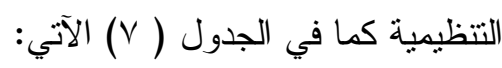

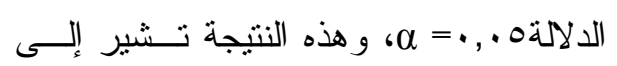

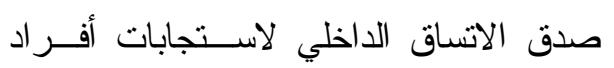

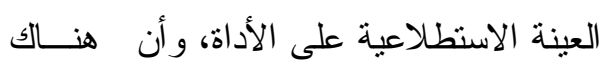




\section{جدول (v)}

معاملات ارتباط كل مجال من المجالات بالدرجة الكلية لمقياس الثقافة التنظيمية

r. $=\dot{0}$

\begin{tabular}{|c|c|c|}
\hline معامل الارتباط & اسم البعد & المحور \\
\hline$\because \cdot, 91$ & ثقافة السياسات الإدارية النتظيمية & الأول \\
\hline$* .90$ & ثقافة المهمة & 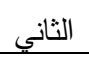 \\
\hline$*, 97$ & ثقافة العمليات & 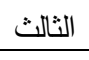 \\
\hline$* \cdot \wedge r$ & نقافة العلاقات الإنسانية & 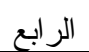 \\
\hline
\end{tabular}

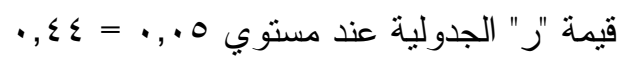

موجبة قوية داله مما يشير إلى أن الاســنبانة

يتضح مسن جـدول (V) معساملات

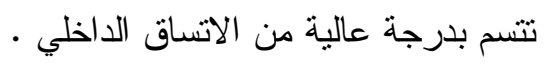

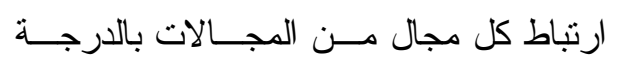

الكلية لمقياس الثقافة التتظيمية هي ارتباطات

(^) جدول (^)

معاملات ارتباط كل فقرة من فقرات مقياس الفاعلية الإدارية مع المجال الذي تنتمي اليه

\begin{tabular}{|c|c|c|c|c|c|}
\hline \multicolumn{2}{|c|}{ تقويم الأداء } & \multicolumn{2}{|c|}{ التدريب و التطوير } & \multicolumn{2}{|c|}{ التخطيط والبناء } \\
\hline معامل الارتباط & م & معامل الارتباط & 5 & معامل الارتباط & s \\
\hline$*, 97$ & 1 & $*, 9 \vee$ & 1 &.$* \wedge \wedge$ & 1 \\
\hline$*, 94$ & $r$ & $*, 97$ & r & $*, 90$ & r \\
\hline$*, \wedge \varepsilon$ & $r$ & $*, \wedge$. & $r$ & $*, \lambda V$ & $r$ \\
\hline *, ג & $\varepsilon$ & $* .09$ & $\varepsilon$ & $*, 9$. & $\varepsilon$ \\
\hline$*, \mathrm{VV}$ & 0 & $*, 9 \vee$ & 0 & $*, V T$ & 0 \\
\hline$\because, 09$ & 7 & & & & \\
\hline
\end{tabular}

قيمة "ر" الجدولية عند مستوي 0 .,. = ع ؟ ـ.

ذات علاقة ارتباطيه دالة إحصائياً بالمجــال

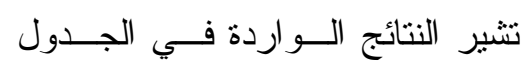

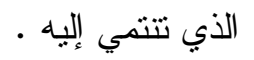

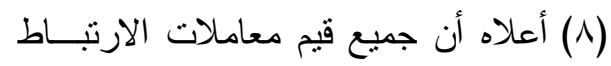

كما تم حساب معامل ارتباط كل فقرة

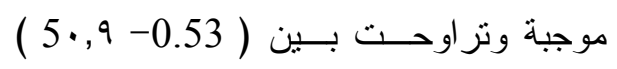

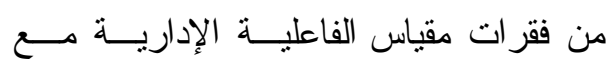

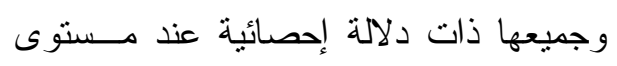

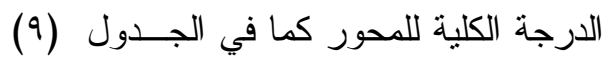

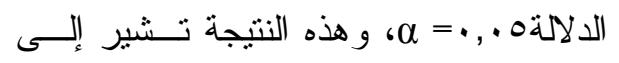

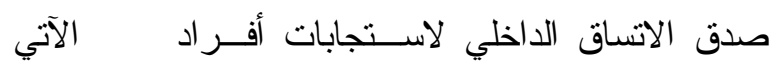

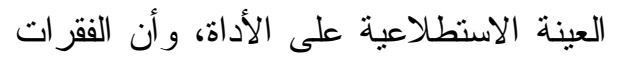




\section{جدول (9)}

معاملات ارتباط كل فقرة من فقرات مقياس الفاعلية الإدارية مع الدرجة الكلية للمحور جلول

\begin{tabular}{|c|c|c|c|c|c|}
\hline \multicolumn{2}{|c|}{ تقويم الأداء } & \multicolumn{2}{|c|}{ التدريب والتطوير } & \multicolumn{2}{|c|}{ التخطيط و البناء } \\
\hline معامل الارتباط & م & معامل الارتباط & م & معامل الارتباط & 5 \\
\hline $0.94 *$ & 1 & $0.90 *$ & 1 & $0.90 *$ & 1 \\
\hline $0.92 *$ & r & $0.99 *$ & r & $0.94 *$ & r \\
\hline $0.85^{*}$ & $r$ & $0.89 *$ & $r$ & $0.90 *$ & r \\
\hline $0.78 *$ & $\varepsilon$ & $0.72 *$ & $\varepsilon$ & $0.89 *$ & $\varepsilon$ \\
\hline $0.76^{*}$ & 0 & $0.94^{*}$ & 0 & $0.65^{*}$ & 0 \\
\hline $0.52 *$ & 7 & & & & \\
\hline
\end{tabular}

قيمة "ر" الجدولية عند مستوي ه.,. = ع §, •

$$
\text { جدول (1. ) ج (1) }
$$

معاملات ارتباط كل مجال من المجالات بالارجة

الكلية لمقياس الفاعلية الإدارية

\begin{tabular}{|c|c|c|}
\hline معامل الارتباط & اسم البعد & البعد \\
\hline$*, 9 \wedge$ & التخطيط و البناء & الأول \\
\hline$*, 90$ & التكريب و النطوير & الثاني \\
\hline$*, 97$ & تقويم الأداء & الثالث \\
\hline
\end{tabular}

قيمة "ر" الجدولية عنــد مـستوي 0 .,.

$$
\cdot, \Sigma \varepsilon
$$

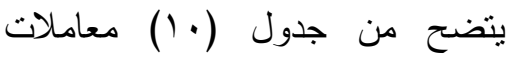
ارتباط كل مجال من المجالات بالدرجة الكلية لمقياس الفاعلية الإدارية هي ارنباطات موجبة قوية داله دما يشير إلى أن الاستبيان يتسم بدرجة عالية من الاتساق الداخلي.
تشير النتائج الواردة في الجـدول (9)

أعلاه أن جميع قيم معاملات الارنباط موجبة وتز اوحت بين( 0.52 - 0.99 ) وجميعهــا

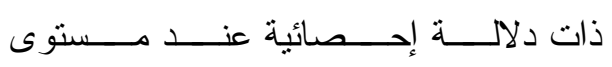
الدلالةه . , •= $\alpha ،$ و هذه النتيجة تـشير إلـى

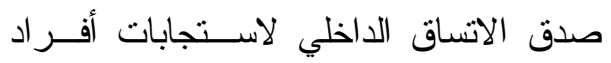
العينة الاستطلاعية على الأداة، وأن الفقرات التيات ذات علاقة ارتباطيه دالــة إحـصائياً مــع الدرجة الكلية للمحور . كما تم حساب معامــل ارتبـــاط كــلـ مجال من المجالات بالدرجة الكلية لمقيــاس

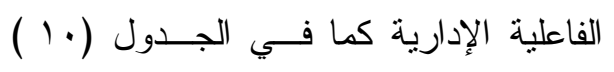
الآتي. 
(الداخلي (ألفا كرونباخ (Alpha cronbah)

تم التأكد من ثبـــات الأداة ، بطريقــــة

التجزئة النصفية، وحساب معامل الاتـساق

جدول(11)

معاملات ثبات مجالات محور الثقافة التنظيمية

\begin{tabular}{|c|c|c|c|}
\hline ثبات ألفا كرونباخ & التجزئة النصفية & 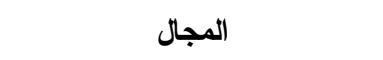 & الرقم \\
\hline$* ., 90$ & $* ., 90$ & ثقافة السياسات الإدارية التنظيمية & 1 \\
\hline$* ., 90$ & $* \cdot, 9 \leq$ & ثقافة المهمة & r \\
\hline$* \cdot, 10$ & $* \cdot, 10$ & تقافة العمليات & r \\
\hline$\because \cdot, \wedge$ & $\because, \wedge \Lambda$ & ثقافة العلاقات الإنسانية & $\varepsilon$ \\
\hline
\end{tabular}

قيمة "ر" الجدولية عند مستوي 0.,.• = ؟ ؟,.

وتم التأكد من ثبات مجــالات محــور

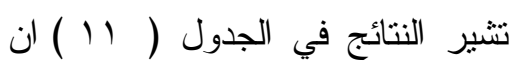

الفاعلية الإدارية ، بطريقة التجزئة النصفية،

معامل الثبات بطريقة الفا كرونباخ انحصر وحساب معامل الاتساق الداخلي ألفا كرونباخ

بين( 0.98 - 0.74 ) وبطريقة التجزئة

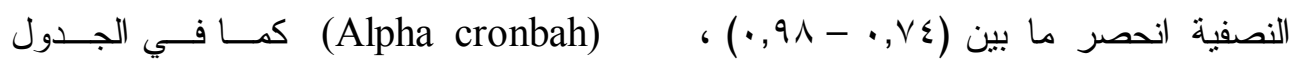
وهي قيمة دالة احصائيا، ومقبولة لإجر اءات الدر اسة.

جدول(Y) (I )

معاملات ثبات اداة الدراسة

\begin{tabular}{|c|c|c|c|}
\hline ثبات ألفا كرونباخ & التجزئة النصفية & المجال & الرقم \\
\hline$*, 91$ & $*, 9$. & التخطيط و البناء & 1 \\
\hline$*, \wedge \wedge$ & $*, \wedge \wedge$ & التدريب و التطوير & $r$ \\
\hline$*, \wedge 9$ & $*, \wedge 9$ & ثقويم الأداء & r \\
\hline
\end{tabular}

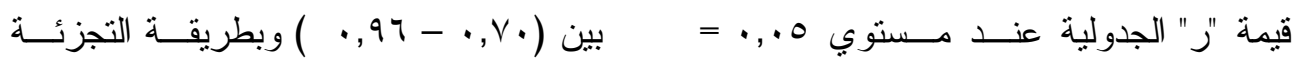
§

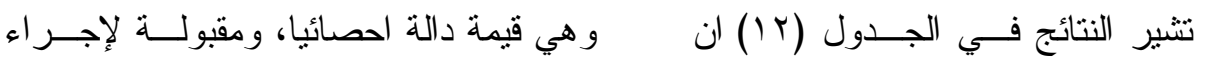

معامل الثبات بطريقة الفا كرونباخ انحصر ل الدراسة. 
تمَّ حساب المتوســطات الحـسابية،

تتائج الدراسة: مناقشتها وتفسيرها

والانحر افات المعيارية لمجالات أداة الدراسة

النتائج المتعلقة بالسؤال الأول:

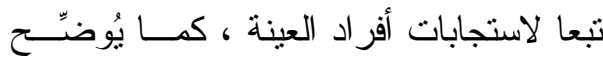

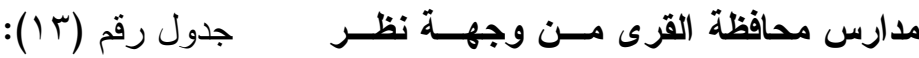

المعلمين ؟. وللإجابة على هذا السؤال:

جدول ( r ا ) المتوسطات الحسابية والانحر افات المعيارية لمجالات اداة الدراسة

حسب متوسطاتها الحسابية.

\begin{tabular}{|c|c|c|c|c|c|}
\hline درجة الممارسة المارة & الرتبة & الالمعراف & الحسابي & الأبعاد & 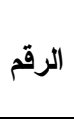 \\
\hline كبيرة & $\varepsilon$ & $\cdot, \mathrm{lV}$ & $r, \wedge т$ & تقافة السياسات الإدارية التنظيمية & 1 \\
\hline 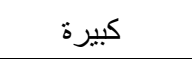 & $\varepsilon$ & $\cdot, \cdot v$ & $\varepsilon, .1$ & نقافة المهمة & r \\
\hline 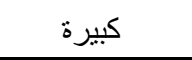 & $\varepsilon$ & $\cdot, .0$ & $r, 97$ & نقافة العمليات & r \\
\hline كبيرة & $\varepsilon$ & $\cdot, \cdot V$ & $\varepsilon, 11$ & تقافة العلاقات الإنسانية (الثقافة المساندة) & $\varepsilon$ \\
\hline 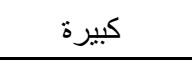 & & $\cdot, 11$ & $r, 9 \wedge$ & الدرجة الكلية & \\
\hline
\end{tabular}

و المعلمين على تطبيقها في الميدان التربوي،

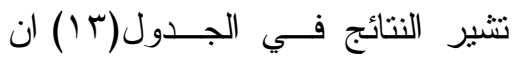

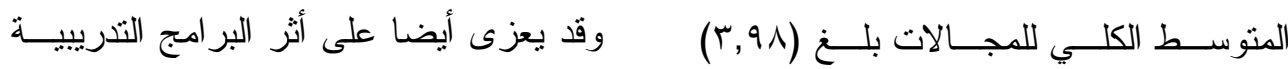

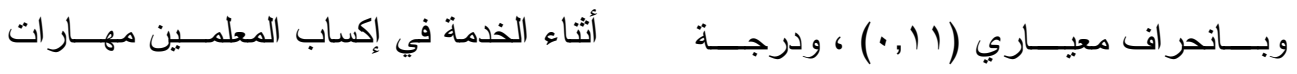

ممارسة كبيرة، وان جميع المجالات جـاءت ومبادئ التقافة التتظيميـة ، و واســتر اتيجيات

بدرجة كبيرة ونر اوحت متوسطاتها الحسابية تطبيقها.

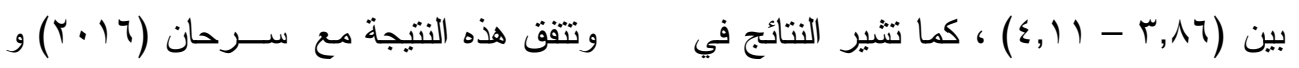

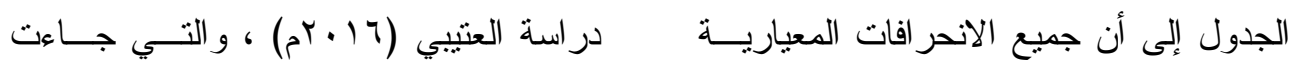

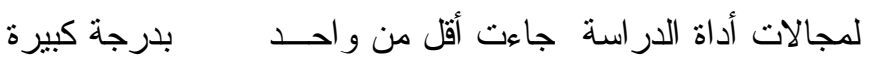

وجاء في المرتبة الاولى مجال ثقافـــة

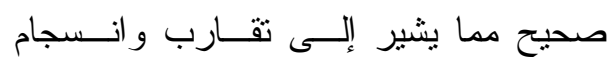

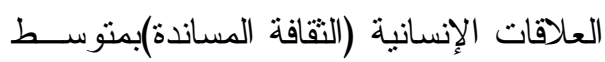

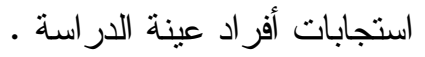

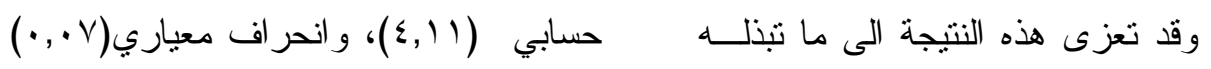

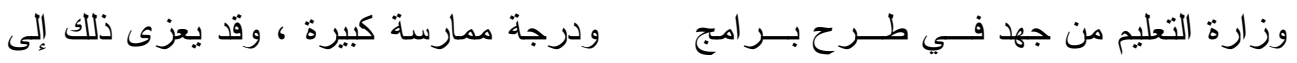

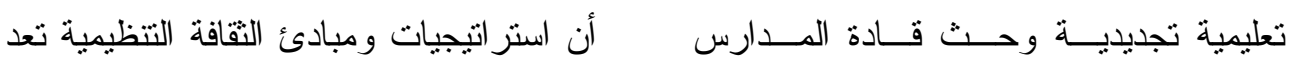


المتوسط الحسابي (r,0 (ץ) بانحر اف معياري

واحدة من أحدث أثنكال التطوير الحادث في

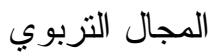

وتختلف هذه النتائج مع در اسة العنود

و هذه النتائج تتفق مع در اسة ماتميناه

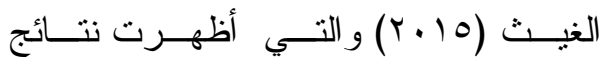

(Mutmainah, 2013)

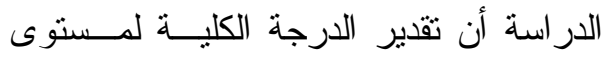

النتائج أن أسلوب القيادة يؤثر تأثثر اً مباثـــــــاً

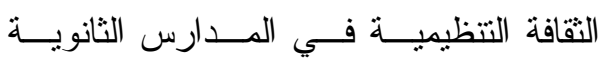

وبشكل كبير و إيجابي في ثقافــة المؤســسة،

الحكومية من وجهة نظر مدير ات المــدارس

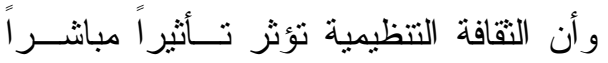

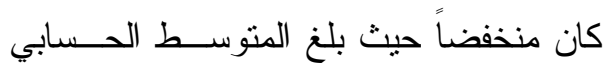

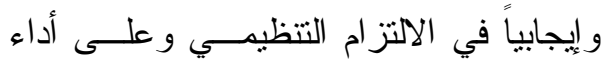

الكلي للمجالات (Y,T) وبانحر اف معياري

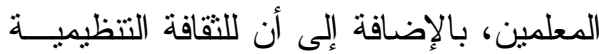

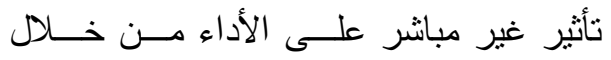

أولاً : مجالات المحور الأول

- ثقافة السياسات الإدارية التنظيمية

تم حسساب المتوســات الحسـابية

الالنز ام التتظيهي للمعلمين.

وتتفق هذه النتائج مع در اسة فاطمــة

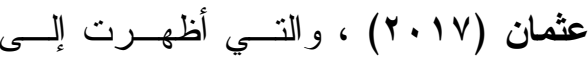

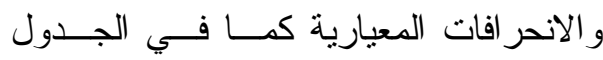

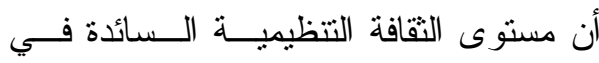

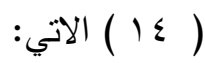

المدارس الخاصة في العاصمة عمــان مــن

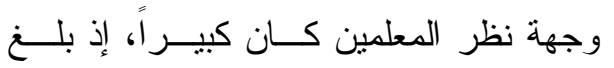

جدول( 1 ( )

المتوسطات الحسابية والاتحر افات المعيارية لمجال ثقافة السياسات الإدارية التنظيمية

\begin{tabular}{|c|c|c|c|c|c|}
\hline اللارجة & 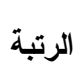 & المعياري & المتوسط المبط & 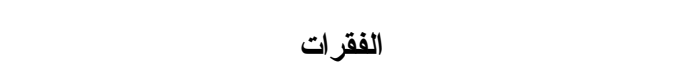 & 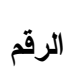 \\
\hline كبيرة & $\varepsilon$ & $\cdot, \wedge \vee$ & r,^৭ & تتوفر سياسات إدارية و اضحة في المدرسة التى اعمل فيها. & 1 \\
\hline كبيرة & $\varepsilon$ & $\cdot, \wedge)$ & $r, q$. & تتسّم الأنظمة و القو انىن المطبقة في المدرسة بالمرونة ـ & r \\
\hline كبيرة جدا & ○ & $\cdot, \wedge \mathrm{T}$ & $\varepsilon, r^{\prime}$ & بالعديز القة. القو اعد و الإجر اءات الإدارية المطبقة في المدرســة & r \\
\hline 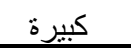 & $\varepsilon$ & $\cdot, 91$ & r,70 & تشرك قبادة المدرسة المعلمين في اتخاذ القر ار ات. & $\varepsilon$ \\
\hline كبيرة & $\varepsilon$ & $\cdot, \wedge 0$ & 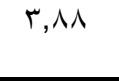 & أُدائه داخل المعلمون بالمدرسة. & $\circ$ \\
\hline كبيرة & $\varepsilon$ & $1,1 \mathrm{~V}$ & r,vr & في بدودية كل عادة المدرسة كل العاملين بمهام ومسؤوليات عملهم & 7 \\
\hline كبيرة & $\varepsilon$ & 1,11 & $r, \wedge 1$ & تتبع قيادة المدرسة الإجر اءات الرسمية في حل المشكلات. & $\mathrm{V}$ \\
\hline كبيرة & $\varepsilon$ & $1, .0$ & $r, \wedge \varepsilon$ & يتوفر معايير معلنة لتقييم أداء المعلمين. & $\Lambda$ \\
\hline كبيرة & & $\cdot, 1 \mathrm{~V}$ & r,人т & الدرجة الكلية & \\
\hline
\end{tabular}


ممارسة كبيرة ، وقد جاءت الفقرة (ع) في

تشير النتائج في الجدول (ع ا ) ) ان

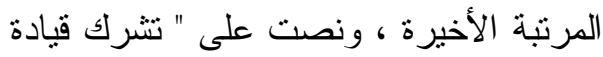

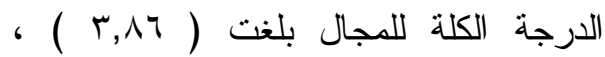

المدرسة المعلمين في اتخاذ القرارات ل

و انحر اف معياري (VI, (•)، بدرجة ممارسة

بمنوسط حسابي (r,

كبيرة، كما تشير النتائج الى ان ( 1 ( ) فقره

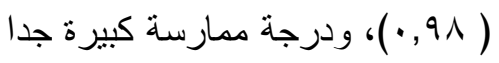

وهذا يعزى إلى أهمية الثقافة

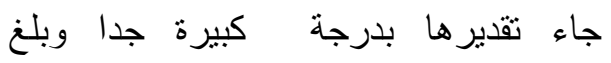

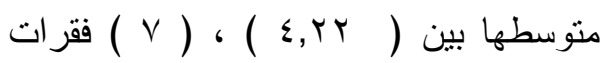
التنظيمية في أن لها تأثيرٌ واضحّ في الهيكل جاء تقديرها بدرجة كبيرة التنظيمي لأي مؤسسة، كما تؤثر في نوع

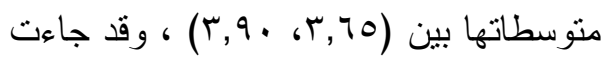

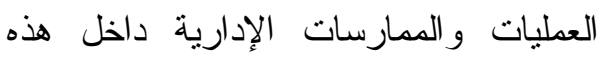
المؤسسة، وأن مواعمة الهيكل التتظيمي

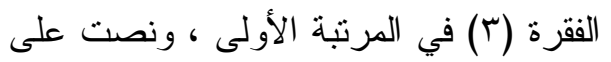
" تتميز القو اعد والإجر اءات الإدارية المطبقة المبة ونهية

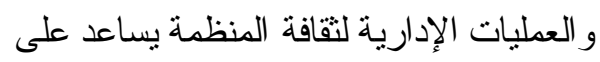
في المدرسة بالعدالة " بمنوسط حسابي تحقيق مزيد من الفاعلية للمنظمة (נ) ( - ثقافة المهمة ودرجة ممارسة كبيرة جدا ، و أن الفقرة تم حسـاب المتوســات الحسـابية

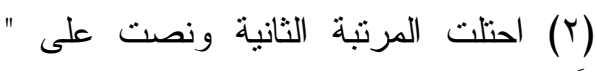
والانحر افات المعيارية كما في الجدول (10) تتسّّم الأنظمة و القو انىن المطبقة في المدرسة

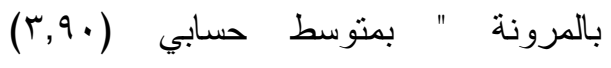

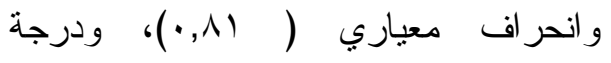

جدول( 1 ) ) المتوسطات الحسابية والانحر افات المعيارية لمجال ثقافة المهمة

\begin{tabular}{|c|c|c|c|c|c|}
\hline 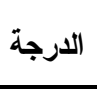 & 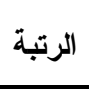 & 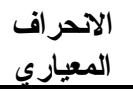 & الحتوسط & الفقرات & 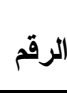 \\
\hline كبيرة & $\varepsilon$ & $\cdot, \wedge 9$ & $r, q 4$ & تركز قبادة المدرسة على الأهداف المرسومة. & 1 \\
\hline كبيرة & $\varepsilon$ & •, 17 & $\{, .7$ & عمصل بسهولة. المعلم على المعلومات التي يحتاجها لأداء & r \\
\hline كبيرة & $\varepsilon$ & $\cdot, 9)$ & $r, q \mu$ & 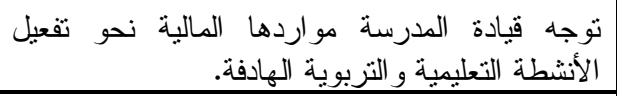 & $r$ \\
\hline 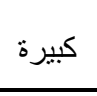 & $\varepsilon$ & •, $\mathrm{YA}$ & $\varepsilon, \cdot \varepsilon$ & تمستج اهم المهني. المدرسة المعلمين على ضرورة الارتقاء & $\varepsilon$ \\
\hline 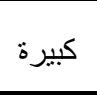 & $\varepsilon$ & $\cdot, 17$ & $\varepsilon, \cdot V$ & تبأول. قيادة المدرسة نتائج الأداء مع المعلمين أول & 0 \\
\hline كبيرة & $\varepsilon$ & $\cdot, \mathrm{V} \varepsilon$ & $\varepsilon, \cdot 1$ & تكافئ قيادة المدرسة المعلمين ذوب الانجاز المتميز. & 7 \\
\hline 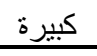 & & $\cdot, \cdot v$ & $\varepsilon, .1$ & الدرجة الكلية & \\
\hline
\end{tabular}




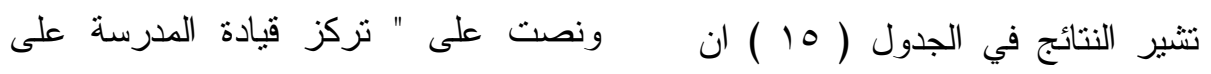

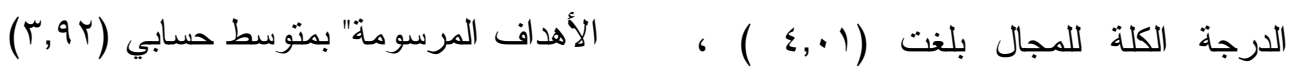

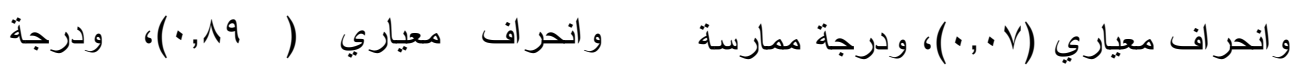

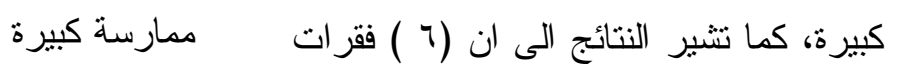

وهذا يعزى إلى أهمية مكافأة قيادة

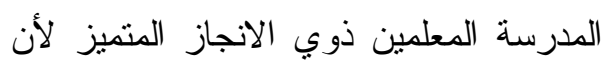
جاء تقديرها بدرجة كبيرة وتراوحت

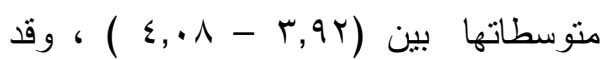
ذللك يحثهم على العمل وكذلك الدافعية

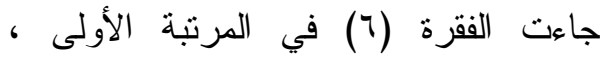
للإنجاز و التقدم وكذللك متابعة أداء المعلمين ونصت على" تكافئ قيادة المدرسة المعلمين أول بأول، وأن مواعمة الهيكل التتظيمي ذوي الانجاز المتميز." بمتوسط حسابي وهادي

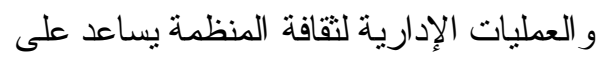

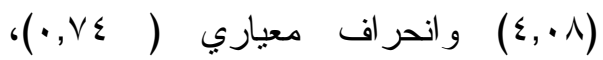
تحقيق مزيد من الفاعلية للمنظمة. ودرجة ممارسة كبيرة ، و و أن الفقرة (0) - ثقافة العمليات

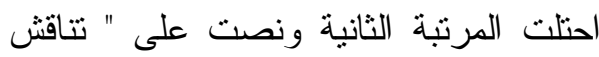
تم حسـاب المتوســات الحسـابية قيادة المدرسة نتائج الأداء مع المعلمين أوله

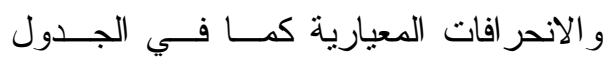

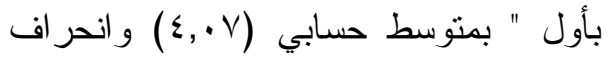
(17)

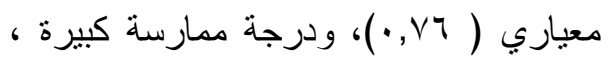

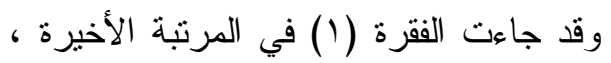
جدول( 19 ) المتوسطات الحسابية والاحر افات المعيارية لمجال ثقافة العمليات

\begin{tabular}{|c|c|c|c|c|c|}
\hline الدرجة & 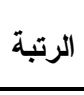 & الآحر اف & الحستوسطي & الفقرات & 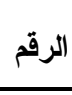 \\
\hline كبيرة & $\varepsilon$ & $\cdot, \mathrm{V}$ & $r, 97$ & تهتم قيادة المدرسة بإنجاز الأعمال في وقتها. & 1 \\
\hline 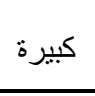 & $\varepsilon$ & $\cdot, V Y$ & r,q. & تإيجابية. تبادل قيادة المدرسة مع التغير ات المجتمعيــة بـصورة & r \\
\hline 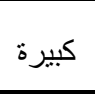 & $\varepsilon$ & $\cdot, \vee \vee q$ & r,q1 & تلتبع قيادة المدرسة إجر اءات نتظيمية تحقـق الأهــــاف & r \\
\hline 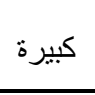 & $\varepsilon$ & $\cdot, V_{1}$ & r,90 & تلته المعلمين قيادة المدرسة أُسساً موضو عىةً في توزىع الأعباء & $\varepsilon$ \\
\hline كبيرة & $\varepsilon$ & $\cdot, 79$ & $\varepsilon, \cdot 1$ & 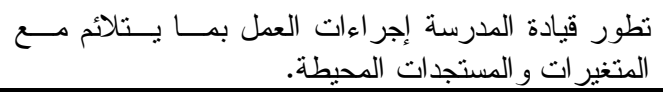 & 0 \\
\hline 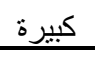 & $\varepsilon$ & $\cdot, \mathrm{\vee} \wedge$ & $\varepsilon, \cdot \vee$ & تعمل قيادة المدرسة على تحقيق التميز في بيئتها المحلية. & 7 \\
\hline كبيرة & & $\cdot, .0$ & $r, 97$ & الدرجة الكلية - الية & \\
\hline
\end{tabular}


تتفاعل قيادة المدرسة مع التغيرات المجتمعية

تشير النتائج في الجدول ( 17 ) ان

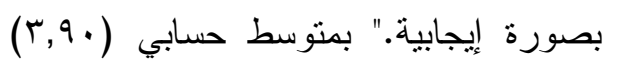

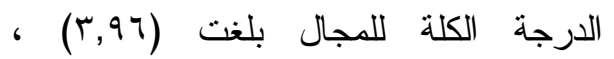

و انحر اف معياري (VY, (·)، ودرجة ممارسة

و انحر اف معياري (0., ,·)، ودرجة ممارسة بلة

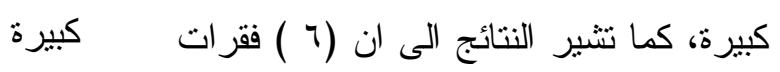

و هذا يعزى إلى أهمية تحقيق التميز

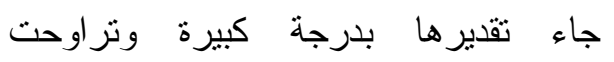

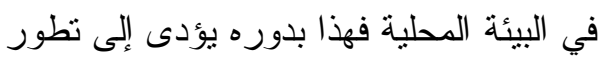

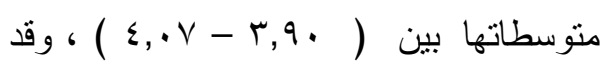

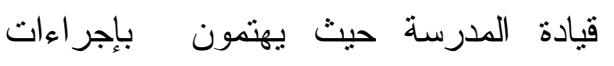

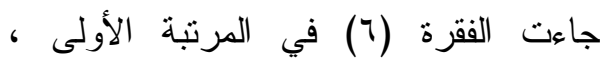
العمل بما يتلائم مع المتغيرات و المستجدات

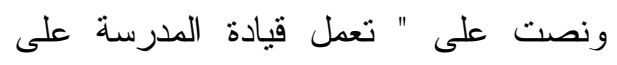
المحيطة ومن هذا المنطلق فإن صناعة التميز سيكون له دور في تطور قيادة تحقيق التميز في بيئتها المحلية." بمتوسط

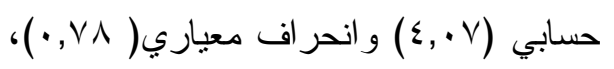
المدرسة.

- ثقافة العلاقات الإنساتية

تم حسـاب المتوســطات الحـسابية

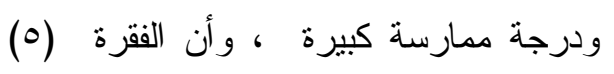
احتلت المرتبة الثانية ونصت على على " تطور

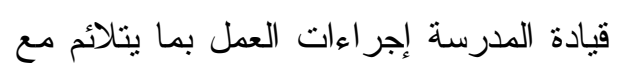

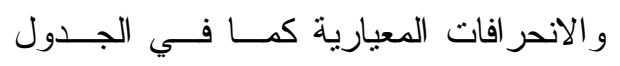

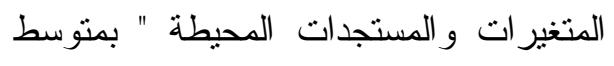
(lV)

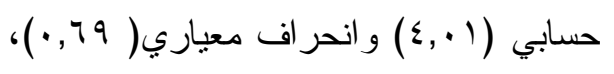
ودرجة ممارسة كبيرة ، وقد جاءت الفرات الفقرة

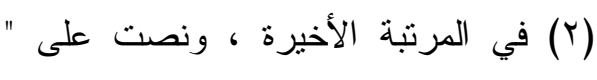
جدول( )

المتوسطات الحسابية و الاحر افات المعيارية لمجال ثقافة العلاقات الإنسانية

\begin{tabular}{|c|c|c|c|c|c|}
\hline الدرجة & الرتبة & 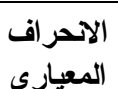 & المتوسط & الفقرات & p \\
\hline كبيرة & $\varepsilon$ & $\cdot, 79$ & $\{, 17$ & نتشجع قيادة المدرسة بناء علاقات إنــسانية إيجابيــة بــين & 1 \\
\hline كبيرة & $\varepsilon$ & $\cdot, \mathrm{V}_{1}$ & $\varepsilon, \cdot \varepsilon$ & تتجبع قيادة المدرسة أداء مهام العمل بروح الفريق & r \\
\hline كبيرة جدا & . & $\cdot, 09$ & $\varepsilon, r$. & تعلبي قيادة الددرسة احتياجات العاملين المختلفة لأداء مهام & r \\
\hline كبيرة & $\varepsilon$ & $\cdot, \wedge)$ & $\varepsilon, 1$. & تثتعر قيادة المدرسة العاملين بالاستقر ار و الأمان الوظيفي. & $\varepsilon$ \\
\hline كبيرة & $\varepsilon$ & 7 & $\varepsilon, .0$ & تمها. قيادة المدرسة العاملين الثقة عند أداء الأعمال المكلفين & 。 \\
\hline كبيرة & & $\cdot, \cdot . \mathrm{V}$ & $\varepsilon, 11$ & الدرجة الكلية & \\
\hline
\end{tabular}


أيضا إلى حرص قيادة المدارس على تلبية

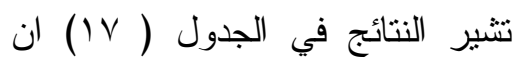

احتياجات العاملين مماسهر في بناء بيئة

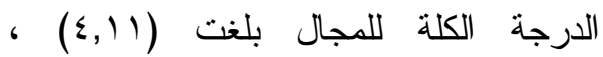

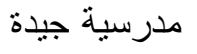

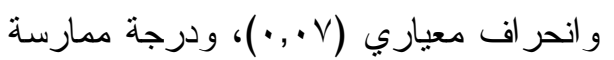
النتائج المتعلقة بالسؤال الثاني والأي نصه: كبيرة، كما تشير النتائج الى ان ( 1 ( ) فقره للإجابة عن سؤال الدراسة الثاني جاء تقديرها بدرجة كبيرة جدا وبلغ والذى ينص على " هل نوجد فروق ذات

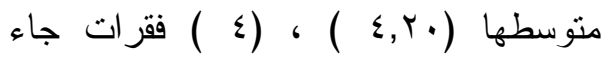

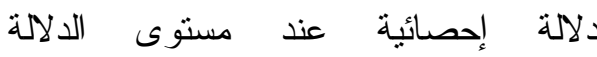
تقدير ها بدرجة كبيرة وتر اوحت متوسطاتها (م)

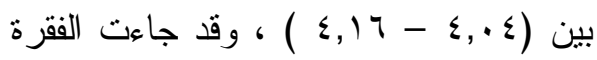
العينة لدرجة نطبيق المعلمين الثقافة (r) في المرتبة الأولى ، ونصت على " ثلبي

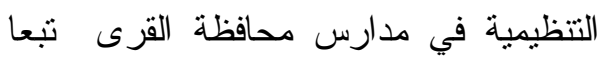
قيادة المدرسة احتياجات العاملين المختلفة

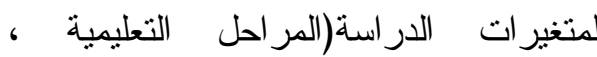

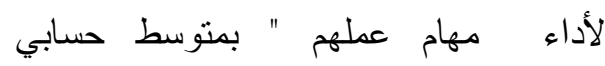
سنوات الخبرة التخصص).

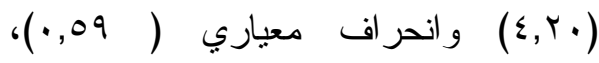
للإجابة عن هذا السؤال تم حساب لت لماب

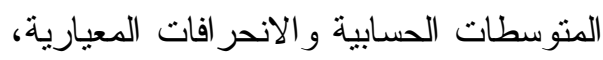
ودرجة ممارسة كبيرة جدا ، و و أن الفقرة

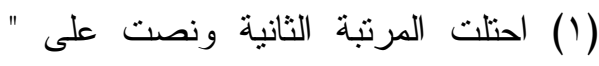
واختبار (ت) ، و اختبار تحليل التباين تشجع قيادة المدرسة بناء علاقات إنسانية الأحادي كما في الجداول الآتية: إيجابية بين العاملين " بمتوسط حسابي لئاء الفروق بين المتوسطات تبعا لمتغير المراحل

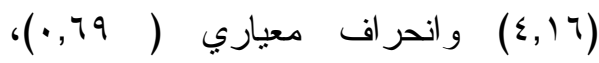
التعليمية :

للكثف عن الدلالة الإحصائية للفروق ودرجة ممارسة كبيرة ، وقد جاءت الفقرة بين متوسطات تقدير أفراد عينة الدراســـة

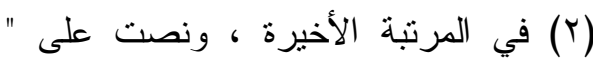

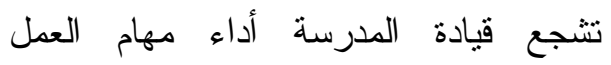

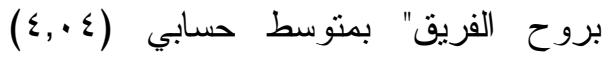

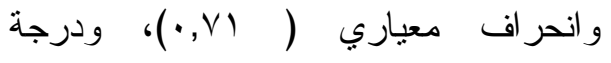

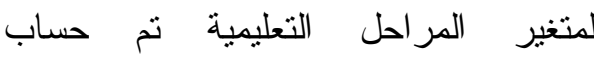
المتوسطات الحسابية والانحر افات المعيارية ممارسة كبيرة لمعرفة الفروق في المتوسطات الحسابية كما

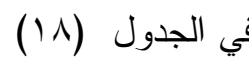
و هذا يعزى إلى أهمية مر اعاة تلبية حاجات العاملين لأداء مهام أعمالهم وهذا لهاء الهاء بطبيعته يؤدى إلى زيادة الإنتاج ويعزى لهاء اعهاء 
جدول (1)

المتوسطات الحسابية والاحر افات المعيارية لمجالات أداة

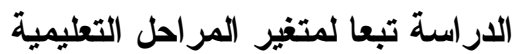

\begin{tabular}{|c|c|c|c|c|}
\hline الاحمراف & المتوسط & العدد & المر احل التعليمية & المجالات \\
\hline • & $r, \lambda \mu$ & ITY & ابتدائي & \multirow{3}{*}{ ثقافة السياسات الإدارية } \\
\hline · & $r, \wedge q$ & o $\varepsilon$ & متوسط & \\
\hline ., or & $r, q \varepsilon$ & $\varepsilon_{0}$ & ثانوي & \\
\hline ., १६ & $r, 99$ & ITV & ابتدائي & \multirow{3}{*}{ ثقافة المهمة } \\
\hline$\cdot, \mu$ & $\varepsilon, \bullet$ & $0 \varepsilon$ & متوسط & \\
\hline ع & $\varepsilon, \cdot r$ & $\varepsilon_{0}$ & ثانوي & \\
\hline · TV & $\varepsilon, Y Y$ & ITY & ابتدائي & \multirow{3}{*}{ تقافة العطليات } \\
\hline •,r & $\{, \cdot 7$ & $0 \leqslant$ & متوسط & \\
\hline., $0 \varepsilon$ & $\varepsilon, 10$ & so & 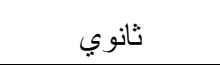 & \\
\hline$\cdot, 79$ & $\varepsilon, i v$ & ITV & ابتدائي & \multirow{3}{*}{ ثقافة العلاقات الإنسانية } \\
\hline • & $\varepsilon, 1$. & o\& & متوسط & \\
\hline$\cdot, Y 4$ & $r, 99$ & 纟o & ثانوي & \\
\hline$\cdot, \varepsilon \vee$ & $\varepsilon, \cdot v$ & ITV & ابتدائي & \multirow{3}{*}{ الدرجة الكلية } \\
\hline •,r & $\varepsilon, \cdot r$ & $0 \leqslant$ & متوسط & \\
\hline 正 & $\varepsilon, .1$ & $\varepsilon_{0}$ & ثانوي & \\
\hline
\end{tabular}

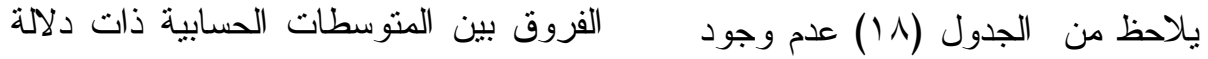

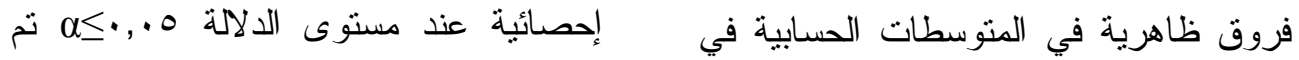

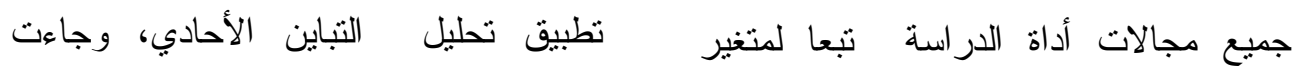

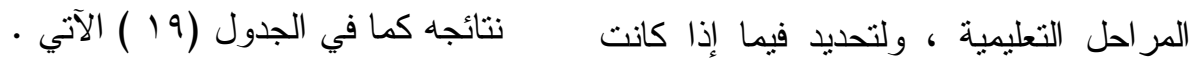




\section{جدول( 9 )}

تحليل التباين الأحادي لاستجابات أفراد عينة الدراسة تبعا لمتغير المراحل التعليمية

\begin{tabular}{|c|c|c|c|c|c|c|}
\hline مستوى الالاية & قيمة ف & المربعات & لدرجات & المربعات & مصدر التباين & المجالات \\
\hline \multirow{3}{*}{$\cdot, 71$} & \multirow{3}{*}{$\cdot, 07$} & $\cdot, r T$ & r & $\cdot, \leqslant 0$ & بين المجموعات & \multirow{3}{*}{ ثقافة السياسات } \\
\hline & & $\cdot$, , & Trt & $\wedge \wedge, r q$ & داخل المجموعات & \\
\hline & & & rro & $\wedge \wedge, \vee \leq$ & الكلي & \\
\hline \multirow{3}{*}{$\cdot, \vee \vee 4$} & \multirow{3}{*}{$\cdot, r V$} & $\cdot, 1 \leq$ & r & $\cdot, r q$ & بين المجموعات & \multirow[t]{3}{*}{ ثقافة المهمة } \\
\hline & & •, or & Trt & 119,19 & داخل المجموعات & \\
\hline & & & rro & $119, \leqslant \wedge$ & الكلي & \\
\hline \multirow[t]{3}{*}{$\cdot, \cdot \wedge$} & \multirow[t]{3}{*}{$1,9 \wedge$} & $\cdot, \wedge T$ & r & $1, \times 1$ & بين المجموعات & \multirow[t]{3}{*}{ ثقافة العمليات } \\
\hline & & • & Trt & $V Y, O$. & داخل المجموعات & \\
\hline & & & rro & $V \varepsilon, Y Y$ & الكلي & \\
\hline \multirow[t]{3}{*}{$\cdot, 1 r$} & \multirow[t]{3}{*}{$r, \cdot 1$} & זד, • & $r$ & $1, r V$ & بين المجموعات & \multirow[t]{3}{*}{ قافة العلاقات الإنسانية } \\
\hline & & • & rrt & 71,70 & داخل المجموعات & \\
\hline & & & rro & $79,9 r$ & الكلي & \\
\hline \multirow[t]{3}{*}{$\cdot, \mathrm{V} \vee$} & \multirow[t]{3}{*}{$\cdot, Y_{T}$} & $\cdot, \cdot r$ & r & $\cdot, \cdot V$ & بين المجموعات & \multirow[t]{3}{*}{ الدرجة الكلية } \\
\hline & & $\cdot, 10$ & שr & 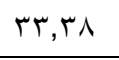 & داخل المجموعات & \\
\hline & & & rTo & Tr, & الكلي & \\
\hline
\end{tabular}

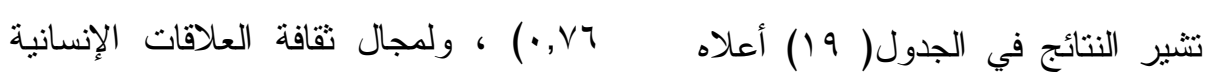

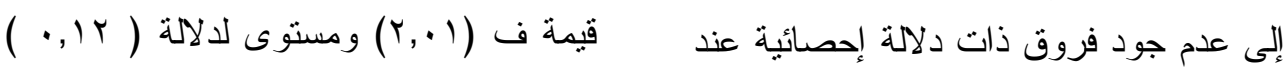

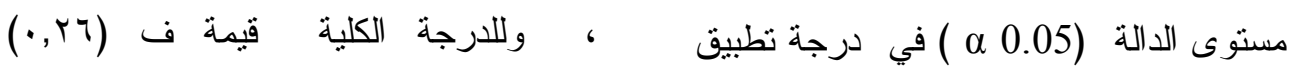

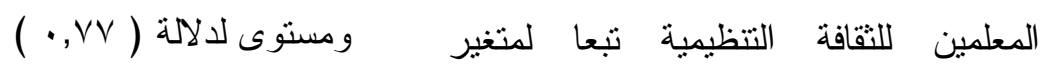
ويعزو الباحث ذلك إلى أن تطبيق

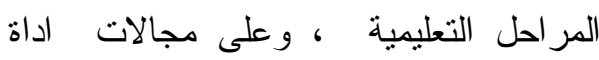
الدر اسة و الدرجة الكلية للمجالات حيث بلغت المعلمين للثقافة التنظيمية يتكيف معها كافة

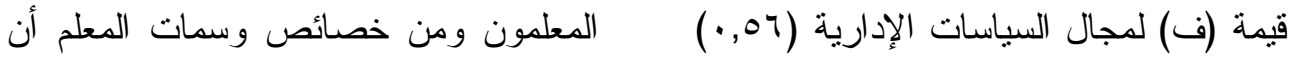

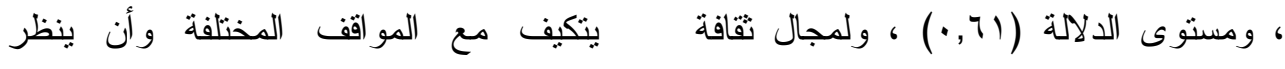

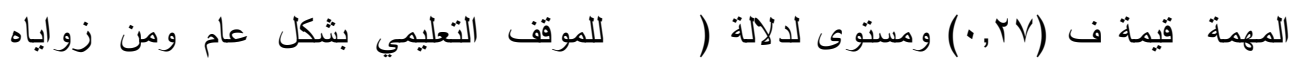


وتختلف هذه النتائج مع دراسة

المطبري (ع إ.ب) الدراسة وكان من أهم

نتائج عدم وجود فروق ذات دلالة إحصائية

بين تقديرات أفراد الدراسة لأنماط الثقافة

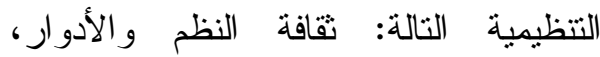
التعاطف الإنساني، الإنجاز تُعزى لمتغير

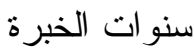

الفروق بين المتوسطات تبعا لمتغير سنوات

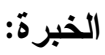

وللكثف عن الدلالة الإحصائية

للفروق بين متوسطات استجابات أفراد عينة الدر اسة لدرجة ممارسة المعلمين الثقافة

التتظيمية في مدارس محافظة القرى تبعا لمتغير سنوات الخبرة و التي فقد تم استخدام إختبار (ت) t.test للمقارنة بين متوسين مستقلين كما يبين الجدول(· r).

المختلفة و هذه المهار ات يمارسها المعلم في كافة المر احل التعليمية .

وهذه النتائج تتقق مع در اسة فريدي

(Freddy, 2014)، ومن أهم نتائج الدر اسة دأن

أنه توجد علاقة إيجابية ذات دلالة إحصائية

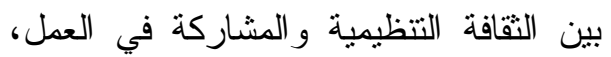
وتوجد علاقة إيجابية دالة إحصائياً بين الثقافة التتظيمية و أداء المعلمين. و هذه النتائج تتفق مع در اسة ماتميناه (Mutmainah, 2013) نتائج الدراسة أن أسلوب القيادة يؤثر تأثنير أ وكان مباشراً وبشكل كبير و إيجابي في نقافة

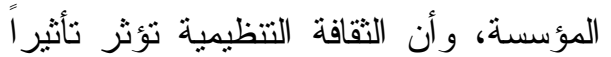

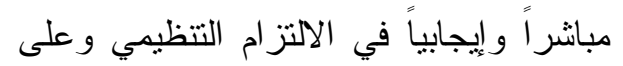

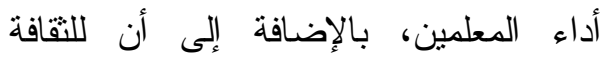

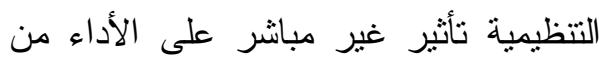
خلال الالتز ام التنظيمي للمعلمين. تلنيز جدول( · r) اختبار (ت) لاستجابات أفراد عينة الدراسة على مجالات أداة الاراسة تبعا لمتغير سنوات الخبرة

\begin{tabular}{|c|c|c|c|c|c|c|}
\hline \multicolumn{2}{|c|}{ اختبار ت } & \multicolumn{2}{|c|}{ 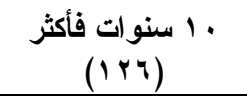 } & \multicolumn{2}{|c|}{ 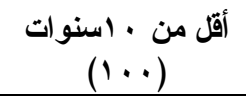 } & \multirow{2}{*}{ المجالات } \\
\hline اللالاية & ق قيمة ت & أمعراف & متوسط & معياري & متوسط & \\
\hline$\cdot, Y \Lambda$ & $1, \cdot v$ &., 00 & $r, 91$ & $\cdot, \mathrm{VI}$ & $r, A r$ & ثقافة السباسات الإدارية \\
\hline 西, & $1, r$ & $0, r_{0}$ & $\varepsilon, \cdot 1$ & $1, .0$ & $r, 90$ & ثقافة المهمة \\
\hline$\cdot, ., 1$ & ${ }^{*} r, q \varepsilon$ & $\cdot, \varepsilon)$ & $\varepsilon, \cdot V$ & $\cdot, \mathrm{v}$. & $\varepsilon, \Gamma_{\uparrow}$ & ثقافة العطليات \\
\hline$\cdot, ., 1$ & "T,Y & $\cdot, Y_{\Lambda}$ & $\varepsilon, .0$ & $\cdot, \mathrm{VT}$ & $\varepsilon, r$. & ثقافة العلاقات الإنسانية \\
\hline .,$Y \varepsilon$ & ., ro & • & $\varepsilon, \cdot r$ & . Or & $\varepsilon, \cdot \wedge$ & الدرجة الكلية \\
\hline
\end{tabular}

*دال إحصائيا عند مستوى الدلالة 0 .,. 
الثقافة التنظيمية في مدارس محافظة القرى تبعا لمتغير سنوات الخبرة ، حيث بلغت قيمة فئه

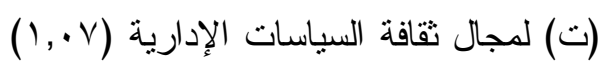

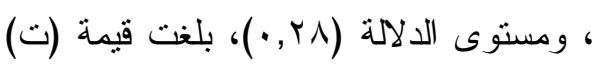

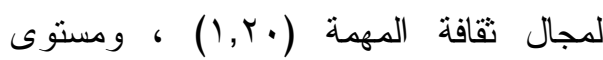

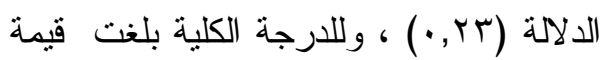

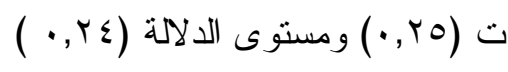
ويعزو الباحث هذه النتيجة إلى ان

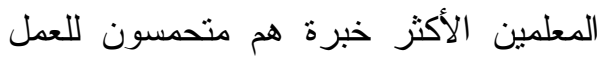
الأكاديمي وأنهم أكثر تقبلا للأفكار التجديدية في اساليب و استر اتيجيات التدريس ، و وأكثر

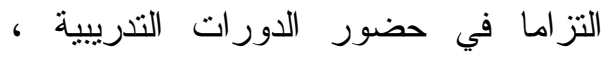
اضافة إلى خبر اتهم العالية فى بالثدريس وخاصة التخصصات التزبوية منهم ولديهم بـاته معارف ومعلومات حول كل ماهو جديد في التدريس ، ولديهم طموحات وظيفية لتحسين مركز هم الوظيفي.

وتتفق هذه النتائج مع در اسة المطيري

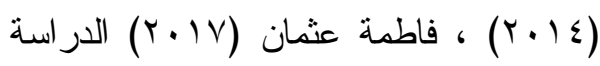
وكان من أهم نتائج الدراسة عدم وجود فروق ذات دلالة إحصائية بين تقدير ات أفراد

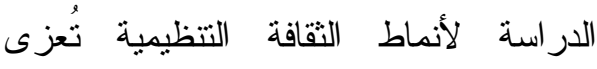
لمتغير سنو ات الخبرة الفروق بين المتوسطات تبعا لمتفير

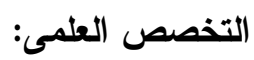

وللكثف عن الدلالة الإحصائية اللفروق بين متوسطات استجابات أفر اد عينة

\begin{abstract}
يلاحظ من الجدول ( · ب) وجود فروق ظاهرية في المنوسطات الحسابية في

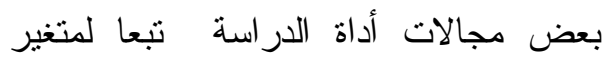
سنوات الخبرة ، و لايوجد فروق ظاهرية في المتوسطات الحسابية في بعض مجالات أداة الدر اسة تبعا لمتغير سنوات الخبرة ولتحديد فيما إذا كانت الفروق بين المتوسطات الحسابية ذات دلالة إحصائية عند مستوى إلى الدان

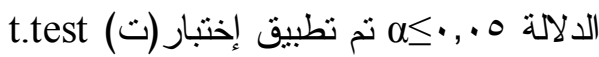
للمقارنة بين منوسطين مستقلين ، وجاءت نتائجه كما في الجدول (· r ) الآتي • وتتشير النتائج في الجدول( · r ) أعلاه إلى وجود فروق ذات دلالة إحصائية

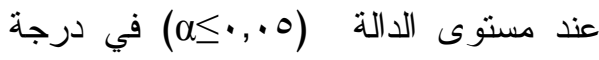
تقدير أفر اد عينة الدراسة لدرجة ممارسة

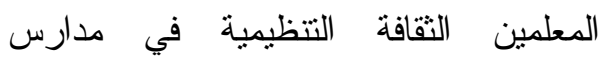
محافظة القرى تبعا لمتغير سنوات الخبرة ، و على مجالات اداة الدراسة و الدرجة الكلية للمجالات حيث بلغت قيمة (ت) لمجال ثقافة

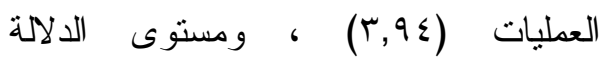
(1)

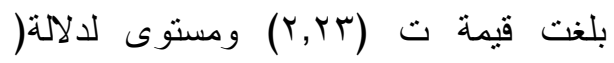
'(,$\cdots)$
\end{abstract} وتثبر النتائج في الجدول أيضا عدم

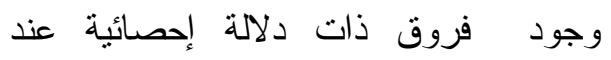

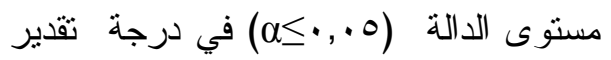
أفر اد عينة الدر اسة لدرجة ممارسة المعلمين 
الار اسة لدرجة ممارسة المعلمين الثقافة استخدام إختبار(ت) t.test للمقارنة بين

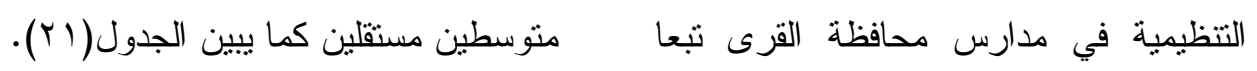

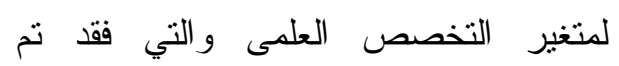
جدول(Y Y) اختبار (ت) لاستجابات أفراد عينة الدراسة على مجالات أداة الدراسة تبعا لمتغير

\begin{tabular}{|c|c|c|c|c|c|c|}
\hline \multicolumn{2}{|c|}{ اختبار ت } & \multicolumn{2}{|c|}{ علوم طبيعية ( V7) } & \multicolumn{2}{|c|}{ علوم إنسانية ( م 1 1) } & \multirow[b]{2}{*}{ المجالات } \\
\hline مستوى الدلالة & قيمة ت & انحر اف & مستوسط & معياري & مسابي & \\
\hline$\cdot, V_{1}$ & דוr, & $\cdot, 07$ & r,人q & $\cdot, 7 \leq$ & r,人т & ثقافة السياسات الإدارية \\
\hline$\cdot, 9 r$ & $\cdot, \cdot \Lambda$ & $\cdot, Y Y$ & $\varepsilon, \cdot 1$ & $\cdot, \wedge \wedge$ & $\varepsilon, \cdot r$ & ثقافة المهمة \\
\hline •, rT & 1,11 & $\cdot, \leqslant 0$ & $\varepsilon, 1 \mu$ & $\cdot, 7 r$ & $\varepsilon, r M$ & ثقافة العمليات \\
\hline$\cdot, \cdot r$ & 1,99 & $\cdot, r_{0}$ & $\varepsilon,+1$ & $\cdot, 70$ & $\varepsilon, 1 V$ & ثقافة العلاقات الإنسانية \\
\hline$\cdot, r_{0}$ & $1,1 \pi$ & $\cdot, r \leqslant$ & $\varepsilon, \cdot 1$ & $\cdot, \leqslant \varepsilon$ & $\varepsilon, \cdot V$ & الدرجة الكلية \\
\hline
\end{tabular}

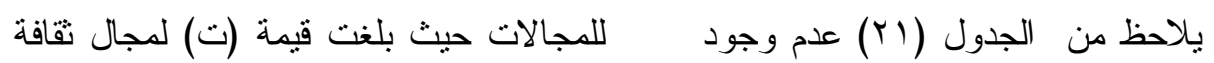

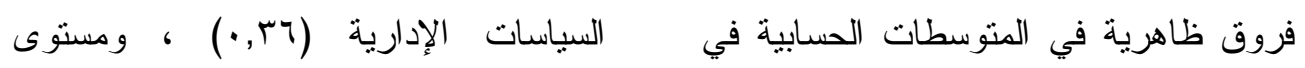

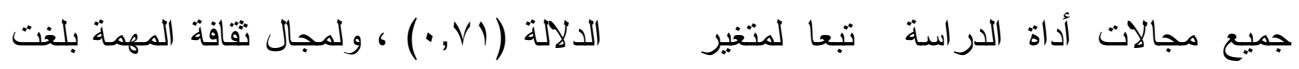

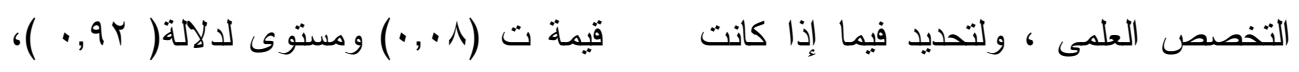

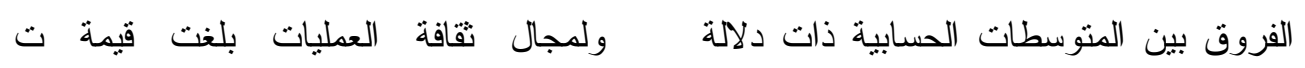

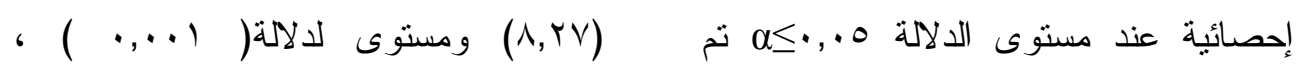

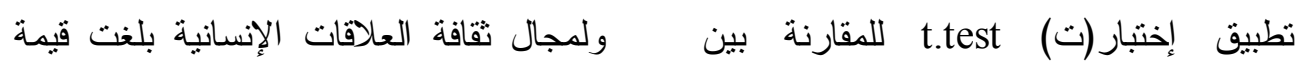

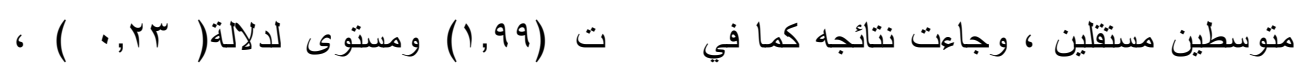

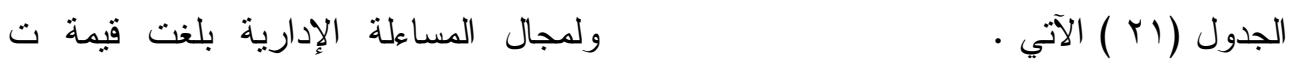
وتنتير النتائج في الجدول( (Y) أعلاه

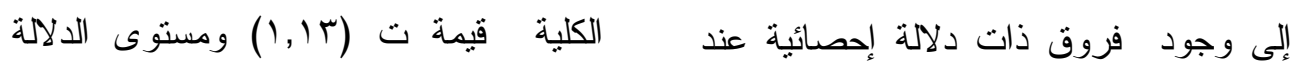

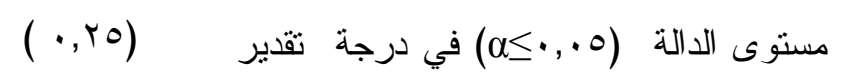

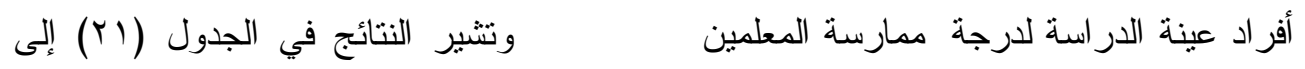

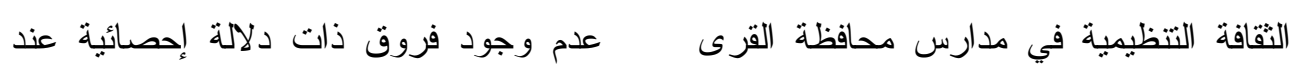

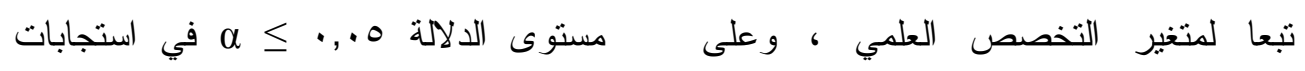

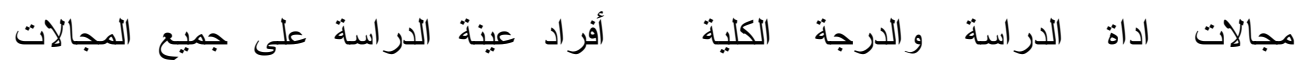


نتائج الدراسة عدم وجود فروق ذات دلالة إحصائية بين أنماط الثقافة التتظيمية الحالية

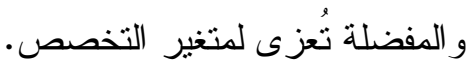
النتائج المتعقة بالسؤال الثالث:

وينص على" ما مستوى الفاعلية الإدارية عند جميع المجالات لاى مدارس

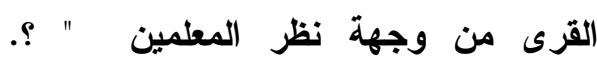
وللإجابة على هذا السؤ ال

تمَّ حساب المتوسطات الحسابية، والانحر افات المعيارية لمجالات أداة الدر اسة تبعا لاستجابات أفراد العينة ، كما يُوضيّح

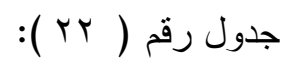

و الدرجة الكلية للمجالات، تبعا لـتغير التخصص العلمي ، وهذا قد يعزى إلى أن

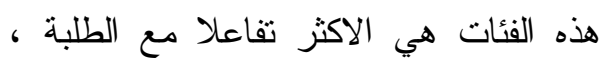
وتوظيفها لاستر اتيجياته من خلال التدريس.

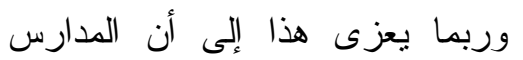
بحاجة إلى برامج تدريبية وتتمية مهنية

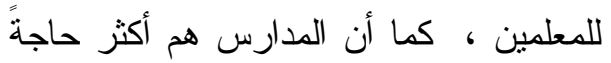
إلى التخصصات العلمية سواء كانت علوم انسانية أو طبيعية وبالتالي أعضاء هيئة التدريس بالمدارس بحاجة الى تتمية مهنية في هذا المجال. وتتفق هذه النتيجة دع نتائج دراسة

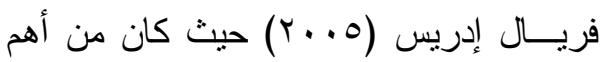
- - مجالات المحور الثاني جدول (r ) المتوسطات الحسابية والاتحر افات المعيارية لمجالات المحور الثاني

\begin{tabular}{|c|c|c|c|c|c|}
\hline درجة الممارسة & الرتبة & الانحر اف & المتوسط الحسابي & الأبعاد & 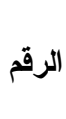 \\
\hline كبيرة & $\varepsilon$ & $\cdot, \cdot \wedge$ & $\varepsilon, \cdot 1$ & التخطيط و البناء & 1 \\
\hline كبيرة & $\varepsilon$ & $\cdot, .0$ & r,qq & التثريب و التطوير & r \\
\hline كبيرة & $\varepsilon$ & $\cdot, \cdot r$ & r,q7 & تقويم الأداء & r \\
\hline كبيرة & & $\cdot, \cdot r$ & $r, 9 \wedge$ & جة الكلية & \\
\hline
\end{tabular}

وقد تعزى هذه النتيجة الى ما تبذله تشبر النتائج في الجدول(r) اند) وزارة التعليم من جهد في طرح هده برهاه

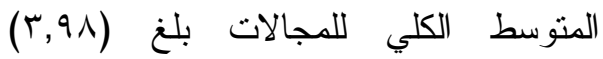

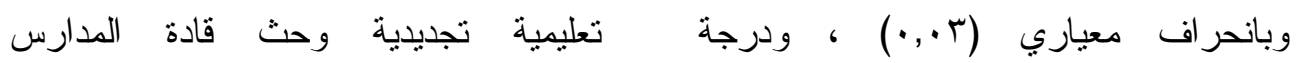

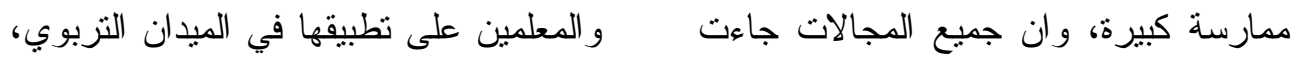

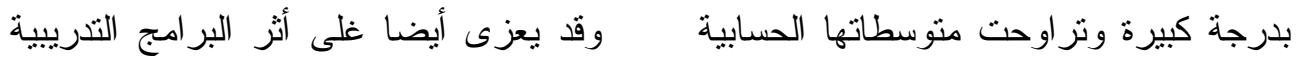

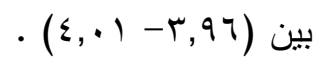


و انحر اف معياري( ^ ^,.•) بدرجة ممارسة

كبيرة ، وقد يعزى ذللك إلى أن ممارسة

الفاعلية الإدارية يحث على العلاقات بين

الإدارة المدرسية والطلاب و أيضا لإدابه روح

التعاون في العمل المدرسي .

- التخطيط و البناء

تم حـساب المتوســـات الحــسابية

والانحر افات المعيارية كما في الجدول (rr)
أثثاء الخدمة في إكساب المعلمين مهارات ومبادئ الفاعلية الإدارية.

وتتقق هذه النتيجة مع دراسة قرموط

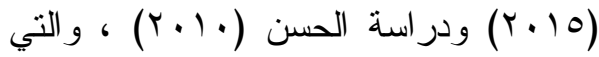

جاءت بدرجة كبيرة وتختلف هذه النتيجة مع

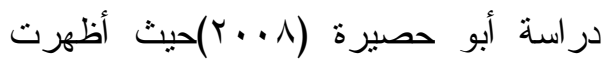

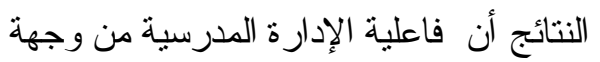
نظر المشرفين التربويين منوسطة

وجاء في المرنبة الاولى مجال

التخطيط و البناء بمنوسط حسابي (1 (, ع)،

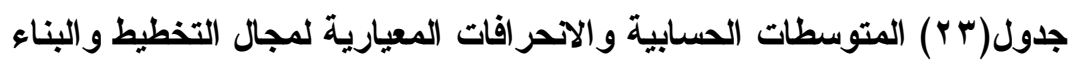

\begin{tabular}{|c|c|c|c|c|c|}
\hline الدرجة & الرتبة & 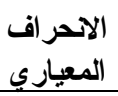 & الحستوسط & الفقرات & 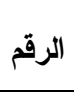 \\
\hline كبيرة & $\varepsilon$ & $\cdot, \mathrm{r}$ & $\varepsilon, 1 \Gamma$ & الموكلة إليهم. & 1 \\
\hline كبيرة & $\varepsilon$ & $\cdot, \wedge 1$ & $r, 99$ & حدنبى قيادة المدرسة خطط بديلة لإدارة الأزمات عند & r \\
\hline كبيرة & $\varepsilon$ & $\cdot, \mathrm{VY}$ & $\varepsilon, \cdot r$ & يتم توزيع المهام داخل المدرسة وفق قدر ات كل العاملين . & $r$ \\
\hline كبيرة & $\varepsilon$ & $\cdot, \vee 9$ & $r, q \vee$ & ورؤدي العاملون بالمدرسة أعمالهم وفق خطة تتفيذية & $\varepsilon$ \\
\hline كبيرة & $\varepsilon$ & $1, .1$ & $r, q$. & 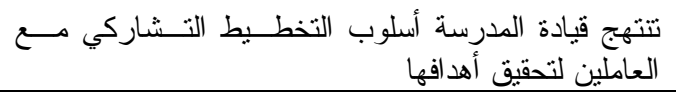 & 0 \\
\hline كبيرة & & $\cdot, \Lambda$ & $\varepsilon, \cdot 1$ & الدرجة الكلية & \\
\hline
\end{tabular}

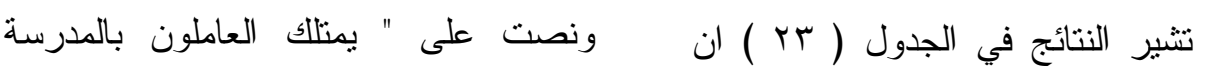

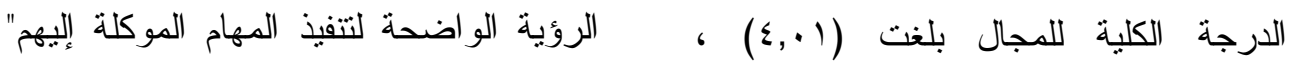

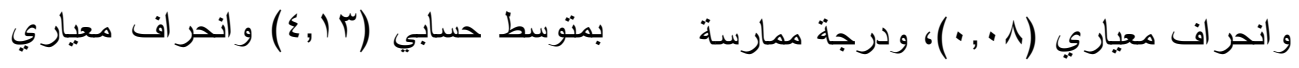

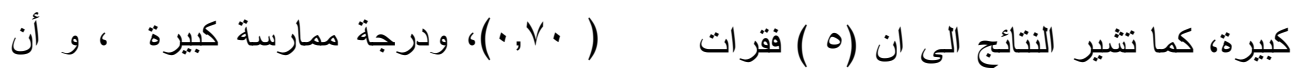

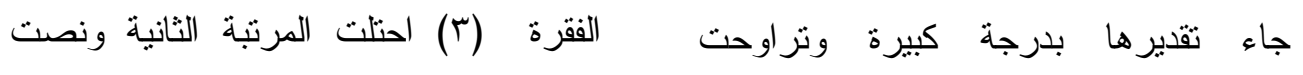

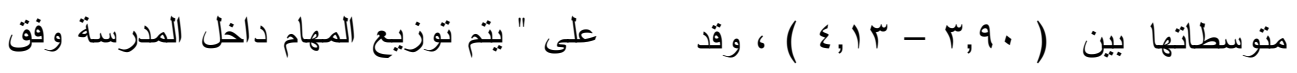

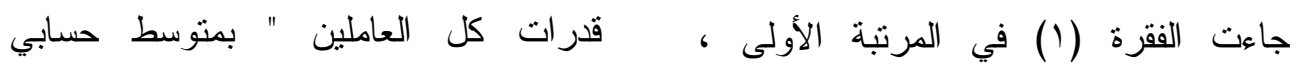

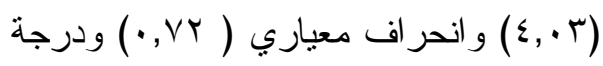


الأعمال المطلوبة وحتى يتم توزيع المهام داخل المدرسة وفق قدر ات كل العاملين

$$
\text { - التدريب و التطوير }
$$

تم حسـاب المتوســطات الحـسابية

والانحر افات المعيارية كما في الجدول (؟ع)

الاتي:

ممارسة كبيرة ، وقد جاءت الفقرة (0) في المرتبة الأخيرة ، ونصت على " تتنهج قيادة ولئ

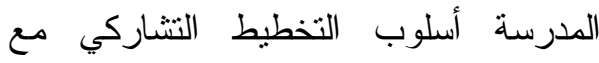
العاملين لتحقيق أهدافها." بمتوسط حسابي

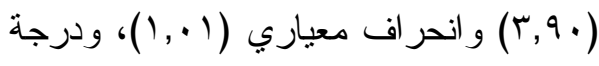
ممارسة كبيرة

وهذا يعزى إلى أهمية وجود رؤية و اضحة حتى يتم العمل من خلالها لتتفيذ جدول(؟ ؟) المتوسطات الحسابية والاحر افات المعيارية لمجال التدريب والتطوير

\begin{tabular}{|c|c|c|c|c|c|}
\hline 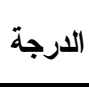 & الرتبة & 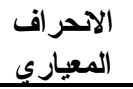 & المتوسط & الفقرات & الرقم \\
\hline 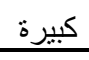 & $\varepsilon$ & $\cdot, \wedge r$ & $r, 99$ & توفر قيادة المدرسة فرص التدريب لجميع العاملين بها. & 1 \\
\hline كبيرة & $\varepsilon$ & $\cdot, 9$. & $r, q 4$ & 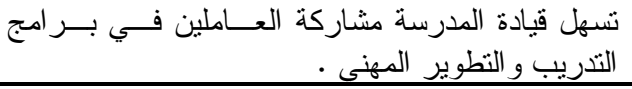 & $r$ \\
\hline كبيرة & $\varepsilon$ & $\cdot, 17$ & $\varepsilon, \cdot \varepsilon$ & 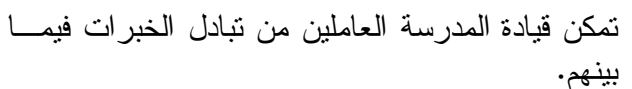 & $r$ \\
\hline كبيرة & $\varepsilon$ & r & $\varepsilon, .1$ & 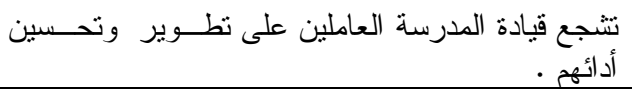 & $\varepsilon$ \\
\hline 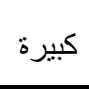 & $\varepsilon$ & $\cdot, \vee \wedge$ & $\varepsilon, \cdot r$ & 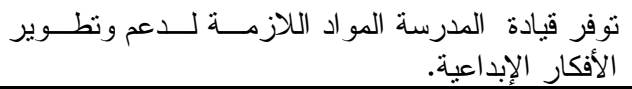 & 0 \\
\hline 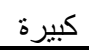 & & $\cdot, .0$ & $r, 99$ & الدرجة الكلية & \\
\hline
\end{tabular}

تثبر النتائج في الجدول (

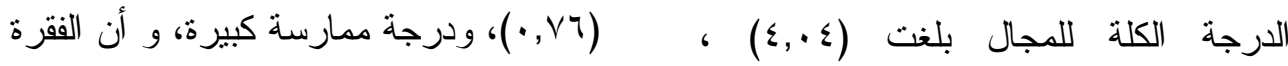

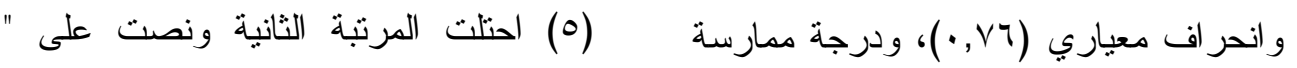

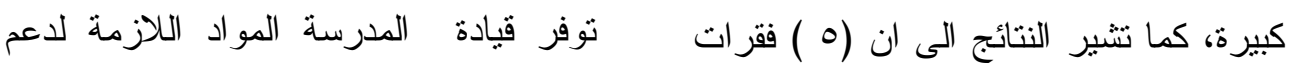

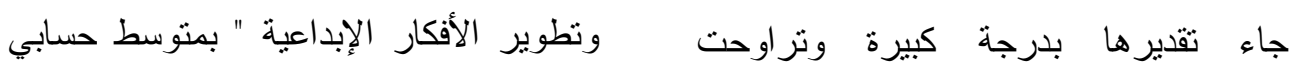

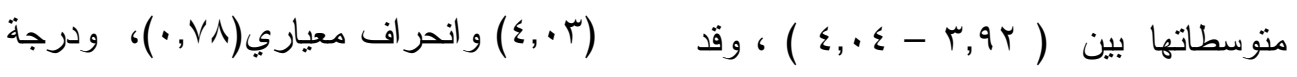

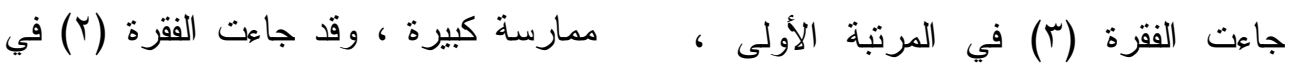

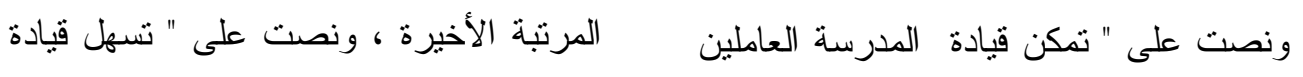

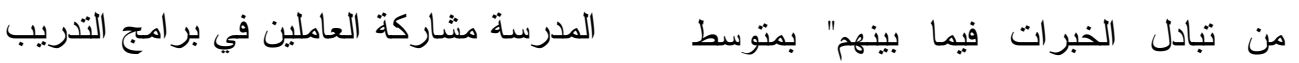


بينهم لأن ذللك لله دور في بناء قاعدة عريضة

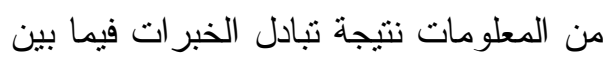
العاملين حتى ينم العمل من خلالها لتتفيذ

$$
\text { الأعمال المطلوبة العين }
$$

و النطوير المهني " بمنوسط حسابي (r,q (r) و انحر اف معياري (·9, •))، ودرجة ممارسة كبيرة

و هذا يعزى إلى أهمية تمكن قيادة المدرسة العاملين من تبادل الخبرات فيما لهات الفيل - - تقويم الأداء تم حساب المتوسطات الحسابية والانحرافات المعيارية كما في الجدول († r) الاتي: جدول(ror) المتوسطات الحسابية والاحمر افات المعيارية لمجال تقويم الأداء

\begin{tabular}{|c|c|c|c|c|c|}
\hline 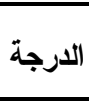 & الرتبة & المعياري المي & | الحستوسطي & 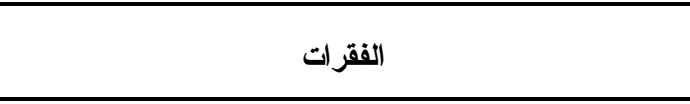 & 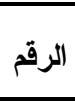 \\
\hline 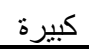 & $\varepsilon$ & $\cdot, 94$ & r,99 & تقبيم قيادة المدرسة العاملين وفق معايير محددة. & 1 \\
\hline 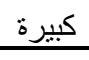 & $\varepsilon$ & $\cdot, \wedge 7$ & $r, 90$ & يهذف التقويم إلى الرقي بمستوى الأداء ـ. & r \\
\hline كبيرة & $\varepsilon$ & $\cdot, \wedge \Lambda$ & $r, 9 r$ & تتنهج قيادة المدرسة نظاما رقابىاً يسهر فى تحقيق أهد افها & $r$ \\
\hline كبيرة & $\varepsilon$ & $\cdot, \mathrm{\vee} 9$ & $\varepsilon,+1$ & تطبق قيادة المدرسة خطة معلنة لإدارة الأداء. & $\varepsilon$ \\
\hline 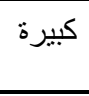 & $\varepsilon$ & $\cdot, V_{1}$ & $r, 99$ & تلتابع قيادة المدرسة مراحل إنجاز العمل الذي يوكل لجميع & 0 \\
\hline 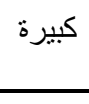 & $\varepsilon$ & $\cdot, 91$ & $r, q \vee$ & فصلي لأعمادة المدرسة جميع العاملين بإعداد مــــ إنجــاز & 7 \\
\hline كبيرة & &.,$+r$ & $r, 97$ & الدرجة الكلية & \\
\hline
\end{tabular}

الثانية ونصت على " تتابع قيادة المدرسة تثنير النتائج في الجدول ( o م ) ان

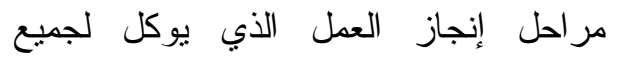
الدرجة الكلة للمجال بلغت (T,97)

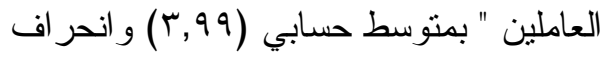

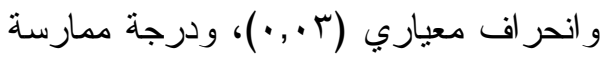

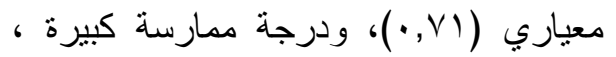

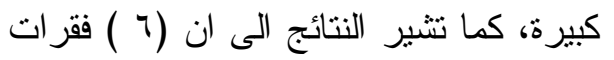

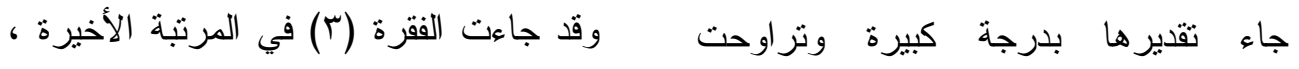

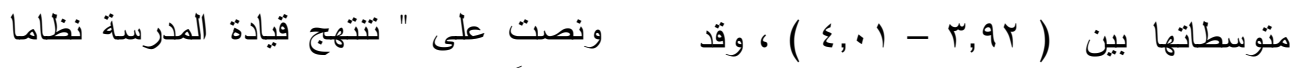

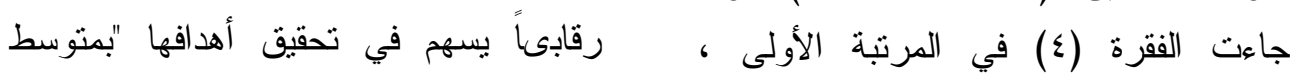

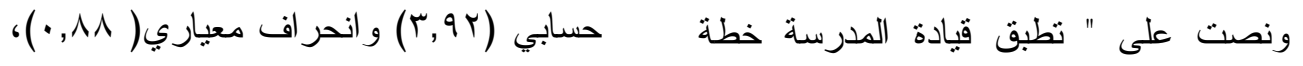

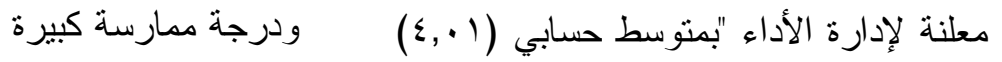

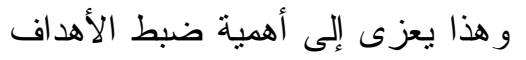

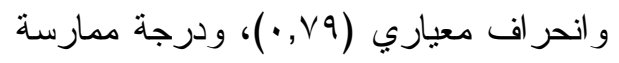

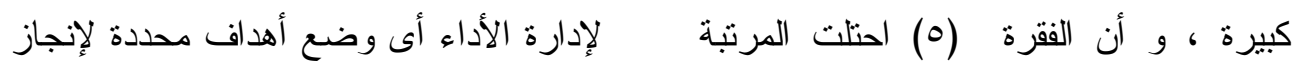


الأداء حتى يتم تحقيق الأهداف المطلوبة ل لمتغيرات الدراسة (المراحل التعليمية،

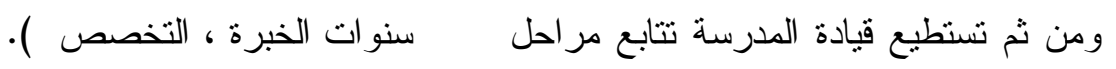
الفروق بين المتوسطات تبعا لمتغير المراحل إنجاز العمل الذي يوكل لجميع العاملين التعليمية : التروف لين النتائج المتعلقة بالسؤال الرابع : للكثف عن الدلالة الإحصائية للفروق

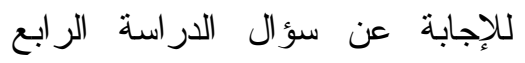
بين متوسطات تقدير أفراد عينة الدراســـة الاحسة

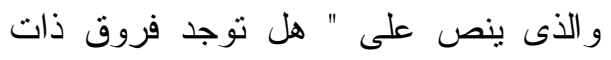

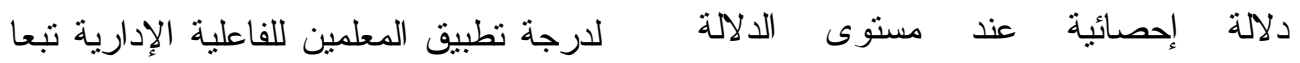

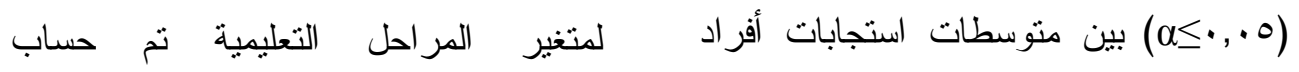
العينة لدرجة ممارسة المعلمين الفاعلية المتوسطات الحسابية والانحر افات المعيارية الإدارية في مدارس محافظة القرى تبعا لمعرفة الفروق في المتوسطات الحسابية كما

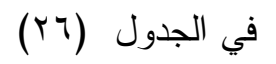

جدول(† r)

المتوسطات الحسابية والاحمر افات المعيارية لمجالات أداة الدراسة تبعا لمتغير المراحل التعليمية

\begin{tabular}{|c|c|c|c|c|}
\hline الاتحر اف & المتوسط & العدد & المر احل التعليمية & المجالات \\
\hline$\cdot, 94$ & $r, q v$ & $1 T V$ & ابتدائي & \multirow{3}{*}{ التخطيط و البناء } \\
\hline • & $\varepsilon, .9$ & $0 \leqslant$ & متوسط & \\
\hline$\cdot, \times 1$ & $\varepsilon,+1$ & $\leq 0$ & ثانوبي & \\
\hline$\cdot, \wedge \wedge$ & r,qv & $1 K V$ & ابتد ائي & \multirow{3}{*}{ التدريب و التطوير } \\
\hline$\cdot, r 9$ & $\varepsilon, .0$ & $0 \leq$ & متوسط & \\
\hline$\cdot, .9$ & $\varepsilon, \cdot r$ & $\leqslant 0$ & ثانوي & \\
\hline $1, \cdot r$ & $r, q r$ & $1 K V$ & ابتذائي & \multirow{3}{*}{ تقويم الأداء } \\
\hline$\cdot, r V$ & $\varepsilon, \cdot 7$ & $0 \leqslant$ & منو سط & \\
\hline$\cdot, \vee \wedge$ & $\varepsilon, \cdot 1$ & $\leqslant 0$ & ثانوي & \\
\hline., 00 & $r, 97$ & $I K V$ & ابتدائي & \multirow{3}{*}{ الدرجة الكلية } \\
\hline$\cdot, 17$ & $\varepsilon, \cdot V$ & $0 \leq$ & متوسط & \\
\hline$\cdot, .0$ & $\varepsilon,+1$ & $\leqslant 0$ & ثانوي & \\
\hline
\end{tabular}

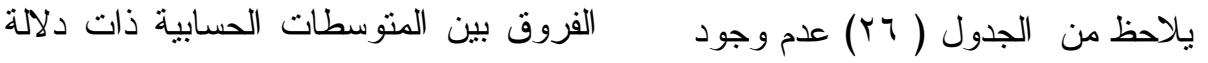

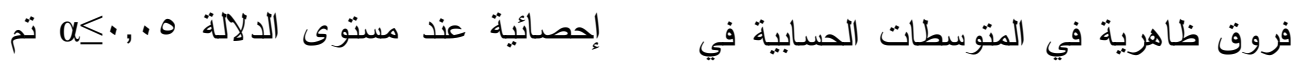

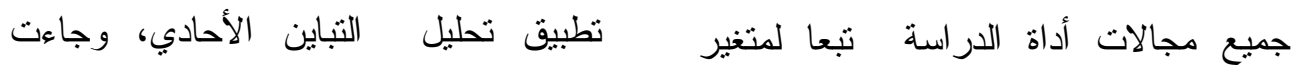
المر احل التعليمية ، ولتحديد فيما إذا كانت نتائجه كما في الجدول (rV ) الآتي: 


\section{جدول(rV)}

تحليل التباين الأحادي لاستجابات أفراد عينة الدراسة تبعا لمتغير المراحل التعليمية

\begin{tabular}{|c|c|c|c|c|c|c|}
\hline مستوى الدلاكة & قيمة ف & متوسط المربعات & الحرية & المربعات & مصدر التباين & المجالات \\
\hline \multirow{3}{*}{$\cdot, 09$} & \multirow{3}{*}{$\cdot$, or } & • & r & $\cdot$, Or & بين المجموعات & \multirow{3}{*}{ التخطيط و البناء } \\
\hline & & $\cdot, \leqslant 9$ & Trt & $111, r v$ & داخل المجموعات & \\
\hline & & & rro & $111,9$. & الكلي & \\
\hline \multirow{3}{*}{$\cdot, \vee \vee$} & \multirow{3}{*}{$\cdot, r V$} & $\cdot, 1 \pi$ & $r$ & $\cdot, Y T$ & بين المجموعات & \multirow{3}{*}{ لتدريب و التطوير } \\
\hline & & $\cdot, \leqslant \vee$ & rTH & $1 \cdot \varepsilon, V \cdot$ & داخل المجموعات & \\
\hline & & & rro & $1 \cdot \varepsilon, 97$ & الكلي & \\
\hline \multirow{3}{*}{$\cdot, 71$} & \multirow{3}{*}{$\cdot, 07$} & $\cdot, \Gamma \leq$ & r & $\cdot, 79$ & بين المجموعات & \multirow{3}{*}{ تقويم الأداء } \\
\hline & & $\cdot, 71$ & rTH & $1 \pi, \varepsilon r$ & داخل المجموعات & \\
\hline & & & rro & IrV,Ir & الكلي & \\
\hline \multirow{3}{*}{$\cdot, r q$} & \multirow{3}{*}{1,11} & $\cdot, r Y$ & r & $\cdot, \leqslant 0$ & بين المجمو عات & \multirow{3}{*}{ الدرجة الكلية } \\
\hline & & $\cdot, 11$ & TrT & Lי, & داخل المجموعات & \\
\hline & & & rro & $\varepsilon \cdot, \vee q$ & الكلي & \\
\hline
\end{tabular}

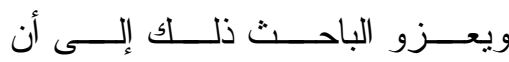

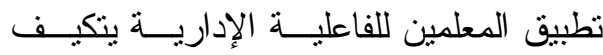

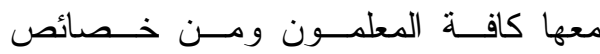

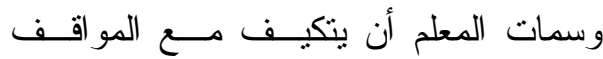

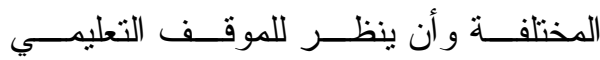

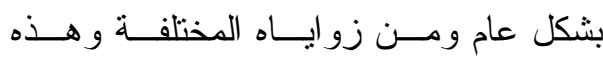

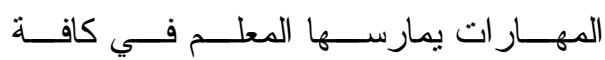

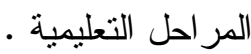

وتختلف هذه النتــائج مــع دراســة

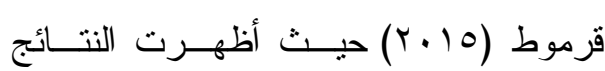

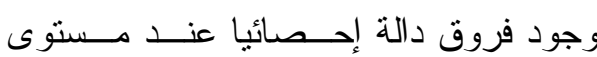

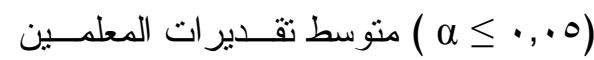

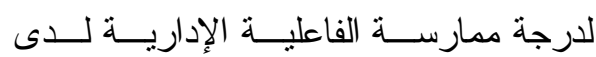

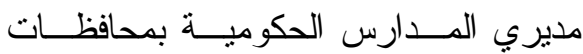

تشير النتائج في الجدول(YV (YV) أعــلاه إلى عدم جود فروق ذات دلالة إحصائية عند مستوى الدالة (0.05 م ) في درجة تطبيق

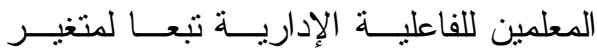

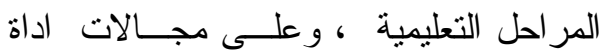
الدر اسة و الدرجة الكلية للمجالات حيث بلغت قيمة (ف) لمجال التخطيط و البناء (Y O, •) ، ومستوى الدلالة (ه9.,) ، ولمجال التنريب

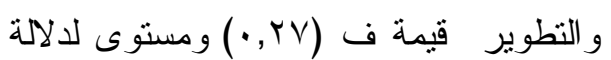

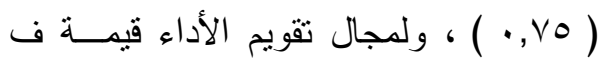

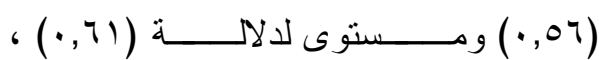
وللارجة الكلية قيمة ف (1,1,) ومسستوى

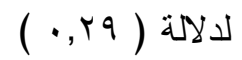


الدر اسة لدرجة ممارسة المعلمين الفاعليــة غزة في الاستبانة الأولى ككل تُعـزى إلـى

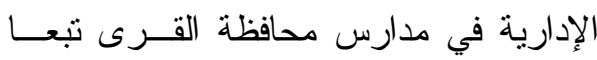

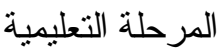
لمتغير ســنوات الخبــرة فقد تــم استخدام إختبار (ت) test للمقارنة بـين متوسير طئسين

$$
\text { مستقلين كما يبين الجدول(Y^). }
$$

الفروق بين المتوسطات تبعا لمتفير سنوات

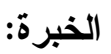
وللكــف عن الدلالـــة الإحــصائية للفروق بين متوسطات استجابات أفراد عينة جدول(r^)

اختبار (ت) لاستجابات أفر اد عينة الار اسة على مجالات أداة الارسة تبعا لمتغير سنوات الخبرة

\begin{tabular}{|c|c|c|c|c|c|c|}
\hline \multicolumn{2}{|c|}{ اختبار ت } & \multicolumn{2}{|c|}{ 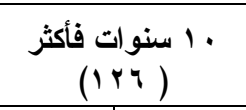 } & \multicolumn{2}{|c|}{ 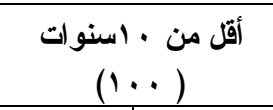 } & \multirow{2}{*}{ المجالات } \\
\hline مستوى & قيمة ت & انحراف & متوسطي & اتحر افي & متوسطي & \\
\hline$\cdot, 1 \leq$ & $1, \leqslant 7$ & $\cdot, r Y$ & $\varepsilon, \cdot V$ & $1, \cdot r$ & $r, q r$ & التخطيط و البناء \\
\hline$\cdot, 11$ & س & שT, & $\varepsilon, .0$ & $\cdot, 99$ & $r, 9 r$ & التذريب و التطوير \\
\hline$\cdot, 1 K$ & 1,7 & $\cdot, r_{1}$ & $\varepsilon, .7$ & $1,1 \leq$ & $r, \wedge q$ & تقويم الأداء \\
\hline$\cdot, \ldots 1$ & *Y, or & $\cdot, 1 \pi$ & $\varepsilon, \cdot V$ & $\cdot, 71$ & $r, q 1$ & الدرجة الكلية \\
\hline
\end{tabular}
* دال إحصائيا عند مستوى الدلالة 0 . ,.

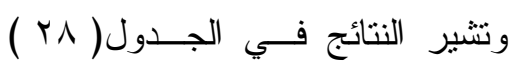
أعلاه إلى وجود فروق ذات دلالة إحصائية

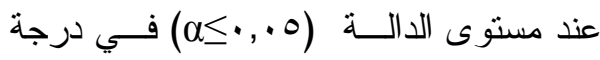

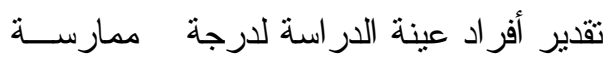

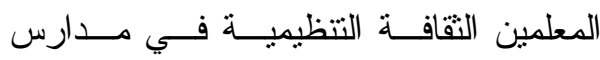

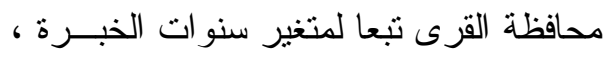
و على مجالات اداة الدراسة و الدرجة الكليــة للمجالات حيث بلغـــت قيمسـة (ت) لمجـــال

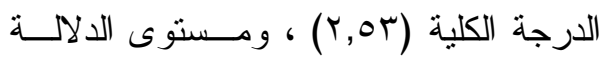
$\cdot(\cdot, \cdot)$

وتشير النتائج في الجدول أيضـا عـدم

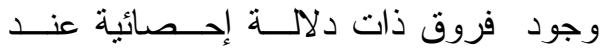

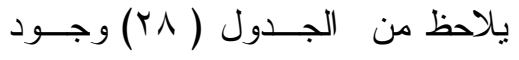
فروق ظاهرية في المتوسطات الحسابية في

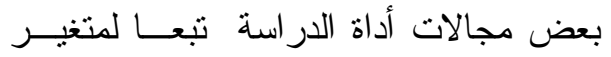
سنوات الخبرة ، و لا يوجد فروق ظاهرية في المتوسطات الحسابية في بعض مجالات أداة الدر اسة تبعا لمتغير سنوات الخبرة ولتحديد فيما إذا كانت الفـروق بــين المتوســـات الحسابية ذات دلالة إحصائية عنــــ مـسنوى

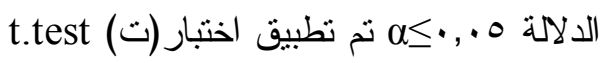
للمقارنة بين متوسطين مستقلين ، وجــاءت

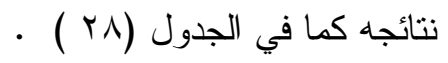


التدريس ، ولديهم طموحات وظيفية لتحسين

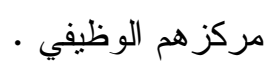

وتتفق هذه النتائج مع در اسة قرموط

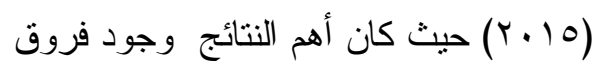

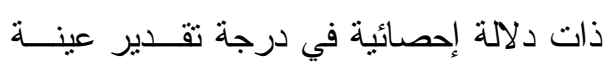

الدر اسة نحو فاعلية أداء المدرسة باســتخدام

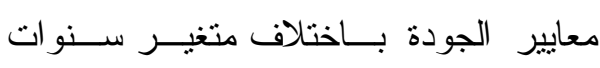

الخبرة. - معاينز

وتتفق هذه النتائج مع در اسة العسيلي

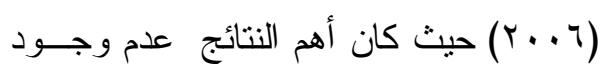
فروق ذات دلالة إحصائية في درجة تقـدير

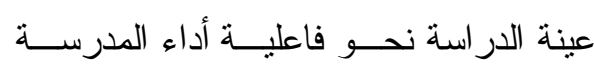

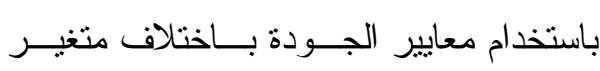

$$
\text { سنوات الخبرة. }
$$

الفروق بـين المتوســـات تبعــا لمتغيــر

$$
\text { التخصص العلمى: }
$$

وللكــشف عن الدالالـــة الإحـــصائية

للفروق بين متوسطات استجابات أفر اد عينة الدر اسة لدرجة مثارسة المعلمين الفاعليـــة

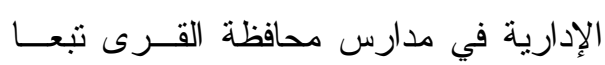

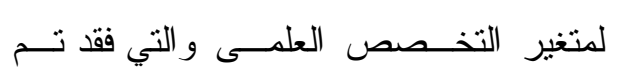

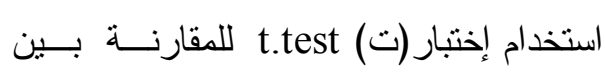

متوسطين مستقلين كما يبين الجدول(ج r).

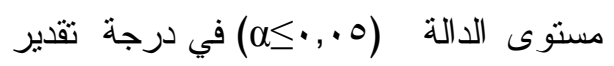
أفر اد عينة الدراسة لدرجة ممارسة المعلمين

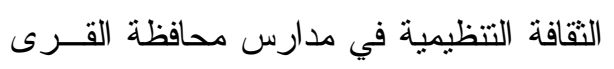
تبعا لمتغير سنوات الخبرة ، حيث بلغت قيمة

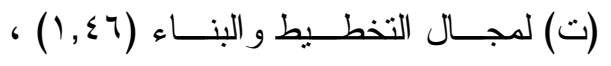
ومستوى الدلالة (ع ا, •)، بلغت قيمسة (ت)

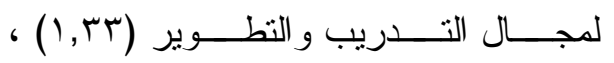
ومستوى الدلالة (1 ا, ·) ، بلغت قيمسـة (ت)

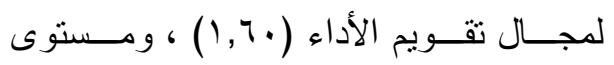
الدلالة (r, (·) ويعزو الباحث هذه النتيجة في دلالتها

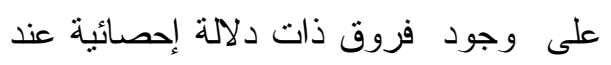

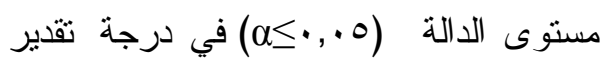
أفر اد عينة الدراسة لدرجة ممارسة المعلمين

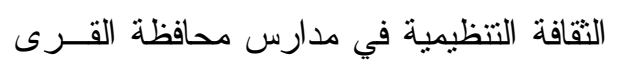
تبعا لمتغير سنوات الخبرة

ويعزو الباحث هذه النتيجة إلـى ان

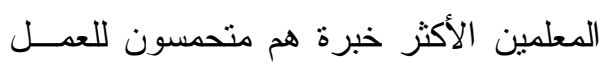
الأكاديمي وأنهم أكثر تقبلا للأفكار التجديدية في اساليب و استر اتيجيات التدريس ، و أكتــر

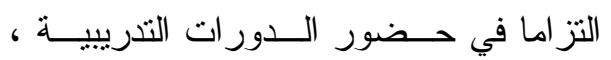
اضافة إلى خبر اتهم العاليــة فـــي التــدريس

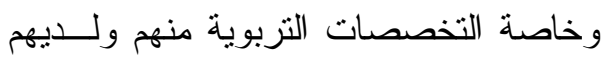
معارف ومعلومات حول كل ما هو جديد في 


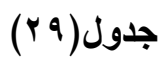

اختبار (ت) لاستجابات أفراد عينة الدراسة على مجالات أداة الدراسة

تبعا لمتغير التخصص العلمي

\begin{tabular}{|c|c|c|c|c|c|c|}
\hline \multicolumn{2}{|c|}{ اختبار ت } & \multicolumn{2}{|c|}{$\begin{array}{c}\text { علوم طبيعية } \\
\text { (V V ) }\end{array}$} & \multicolumn{2}{|c|}{ 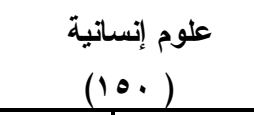 } & \multirow{2}{*}{ المجالات } \\
\hline مستوى الدلالة & قيمة ت & معياري & مستوسط & معياري & مسابي & \\
\hline$\cdot, 10$ & $\cdot, 11$ &., 11 & $\varepsilon, \cdot r$ & $\cdot, \wedge 4$ & $\varepsilon,$. & التخطيط و البناء \\
\hline$\cdot$, AV & $\cdot, 17$ & $\cdot, r_{1}$ & $\varepsilon, \cdot 1$ & $\cdot, Y \Lambda$ & $r, 99$ & للتدريب و النطوير \\
\hline$\cdot, \mathrm{VT}$ & •, ro &., $1 \mathrm{~V}$ & $\varepsilon, \cdot 1$ &., 90 & $r, 9 v$ & تقويم الأداء \\
\hline • & $\cdot, \varepsilon)$ & $\cdot, .9$ & $\varepsilon, .1$ &., 01 & $r, 91$ & الدرجة الكلية \\
\hline
\end{tabular}

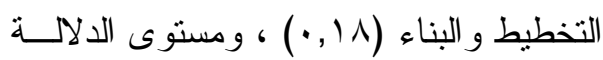

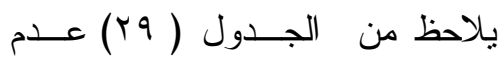

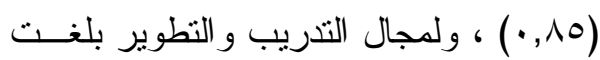

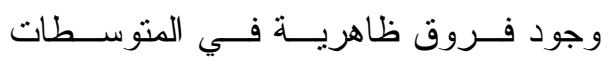

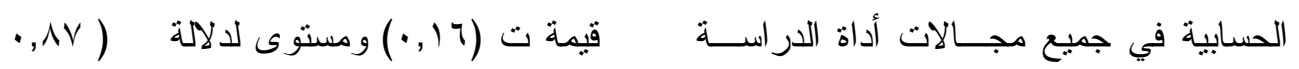

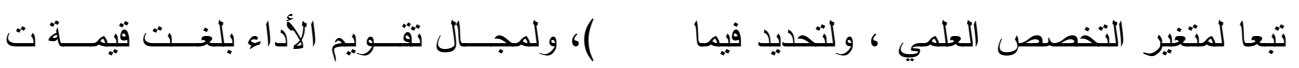

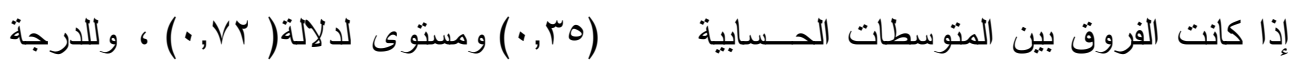

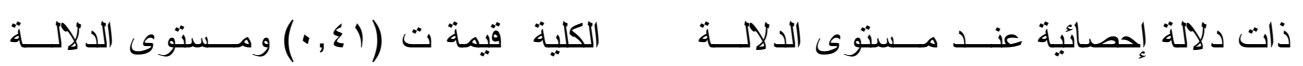

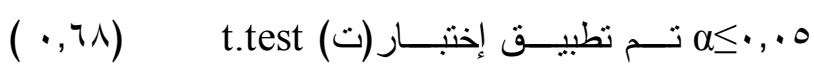

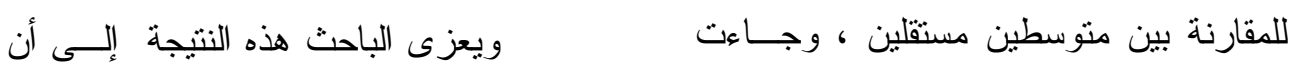

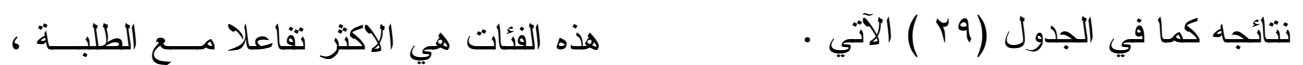

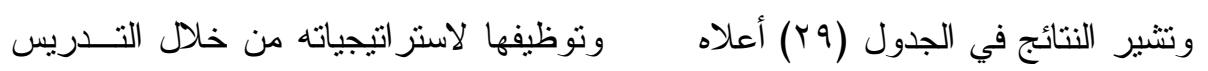

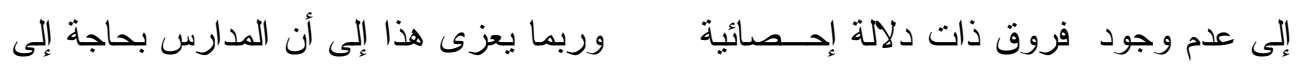

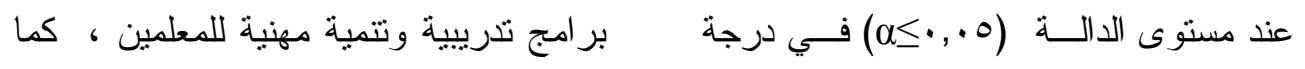

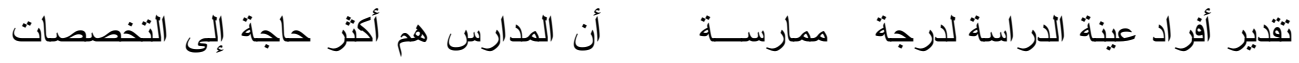

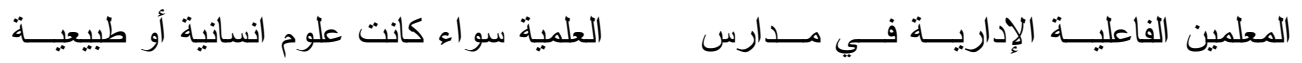

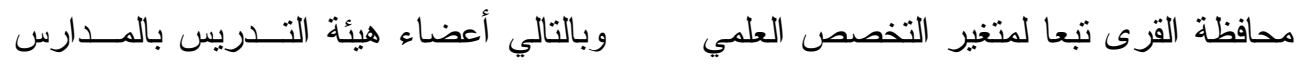

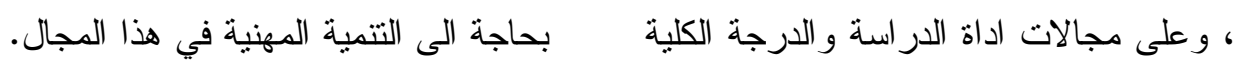

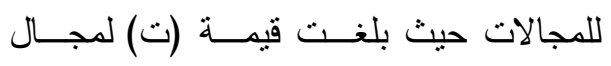




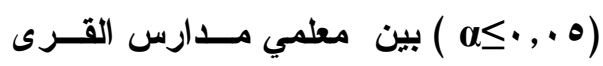

للثقافة التنظيمية ومستوى الفاعلية الإدارية لاى المعلمين

وللتعرف على طبيعة العلاقــة بــين

تطبيق معلمي مـــارس القـــى للتثقافــة

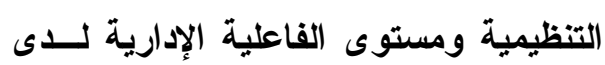

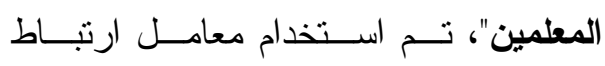

بيرسون وذللك يتضح من خلال الجدول(•r)

الآتي: - اليزسون
وتتفق هذه النتيجة مع نتائج دراســة

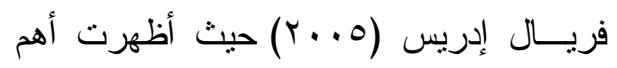

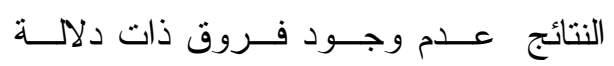

إحصائية بين أنماط الثقافة التنظيمية الحاليــة و المفضلة تُعزى لمتغير التخصص. النتائج المتعلقة بالسؤال الخامس:

للإجابة عن سؤال الدر ساسة الخــامس

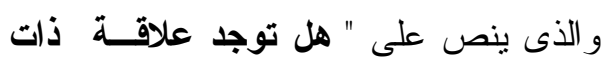

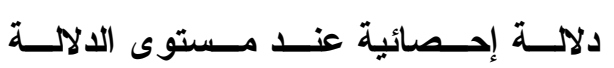

جدول( • "r) معامل ارتباط بيرسون بين تطبيق معلمي مدارس القرى للثقافة التظظيمية ومستوى الفاعلية الإدارية لاى المعلمين

\begin{tabular}{|c|c|c|c|c|c|}
\hline \multicolumn{4}{|c|}{ مستوى الفاعلية الإدارية } & \multirow{3}{*}{ الثقافة التظيمية } & \multirow{3}{*}{ p } \\
\hline الارجة الكلية & تقويم & التدريب & التخطيط & & \\
\hline للفاعلية الإدارية & 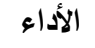 & و التطوير & 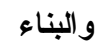 & & \\
\hline$*, 91$ & $\because, \wedge 9$ & $*, r \varepsilon$ & $\because, r q$ & ثقافة السياسات الإدارية التنظيمية & 1 \\
\hline$*, V Y$ & $*, 7$. & *, r & $*, \wedge \uparrow$ & ثقافة المهمة & r \\
\hline$*, \vee$. & $*, 70$ & $*, \sum \wedge$ & $*$, ז० & ثقافة العمليات & r \\
\hline$*,\{\wedge$ & $*, 0 \leqslant$ & $*, 01$ & $*, 79$ & ثقافة العلاقات الإنسانية & $\varepsilon$ \\
\hline$*, 01$ & $*, 09$ & * & *,9r & الدرجة الكلية للثقافة التتظيمية & \\
\hline
\end{tabular}

*دال إحصائيا عند مستوى الدلالة 0 .,.

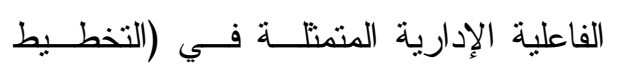

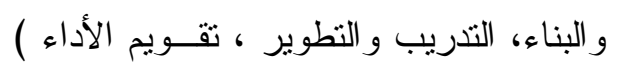

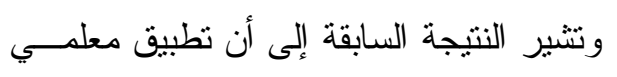

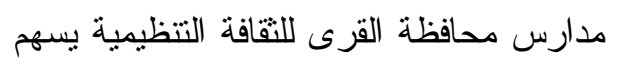

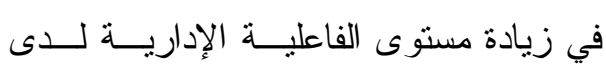

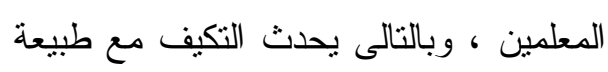

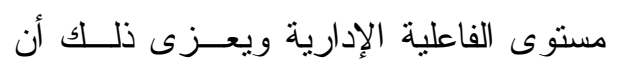

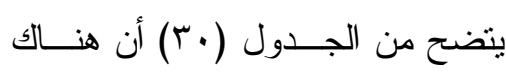

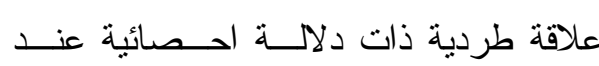

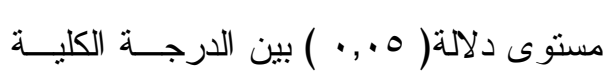

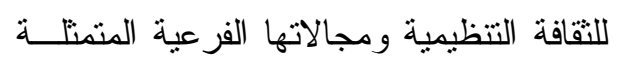
في (ثقافة السياسات الإداريــة التتظيميــة ،

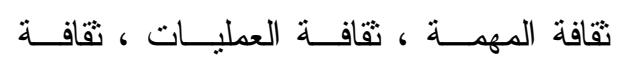

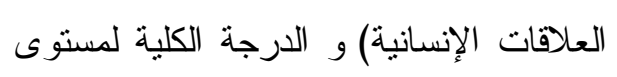


المدرسة وبالإضافة إلى بناء العلاقات الطيبة

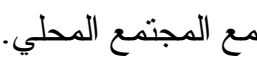

ويؤكد ذلك أيضاً در اســـة قرمــوط

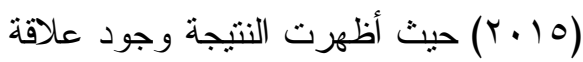

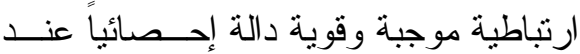

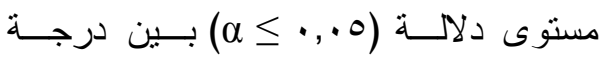
ممارسة الجودة الإدارية ودرجة فاعلية الأداء لأى أفر اد عينة الدر اسة.

ملخص نتائج الدراسة والتوصيات والمقترحات أولا: ملخص نتائج الدراسة :

أهم النتائج التي توصلت إليها الدراسة: - أظهرت نتائج الدراسة أن تطبيق النقافة

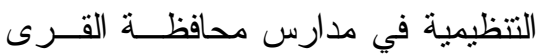
جاءت بدرجة كبيرة وبمتوسط حسسابي

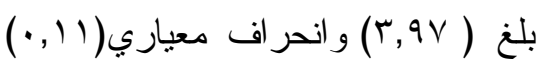
هرت نتــائج الدراســة أن ممارســـة الفاعلية الإدارية جاء بدرجــة كبيــرة

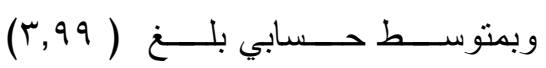
و انحر اف معياري (س +. ••) - أظهرت نتائج الدر اسة أن مجــالات أداة

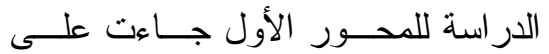
النحو الآتي • جاء مجال ثقافة العلاقــات الإنــسانية (التقافة المساندة) في المرتبة الأولـى لـى لإنى وبمتوسط حسابي (؟),

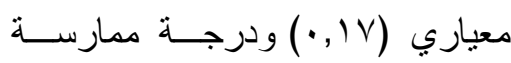
كبيرة.
الثقافة التنظيمية تحقق أهداف المنظمة بشكل يرضى القائمين على المنظمة ، و المستفيدين

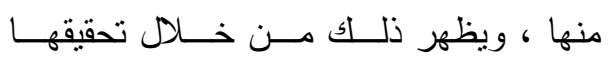

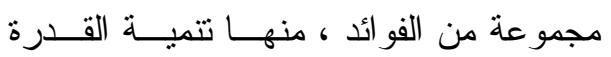

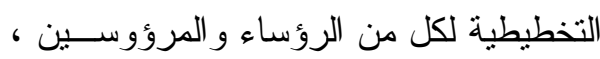

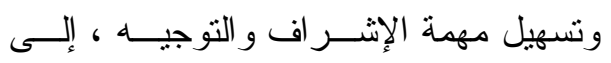
جانب المساعدة في التعرف على المـشكلات الفعلية للعمل الحالية و المسـتقبلية ، وتقويــة

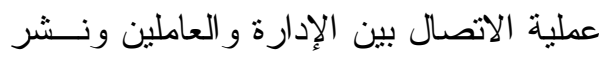
وتبادل المعلومات ويؤكد ذلك دراسة هلال ( • • • م م ) أنه إذا كانت مهمة الإدارة هي القيام بالمهــام

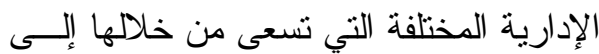

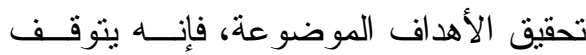

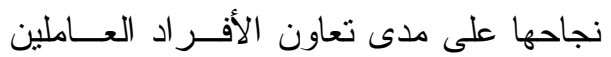
فيها بالقيام بالمهام الموكلة إليهم ومدى تقبلهم و استعدادهم لبذل أقصى طاقاتهم، فإذا توفرت

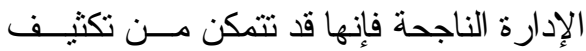
جهود أفر ادها و العمل على تحفيز هم نحو القيام بوظائفه كما يجب. ويؤكد ذلك در اسة در داسة دي ستنفانو (DeStefano, 2003) ، وقد أظهرت نتائج

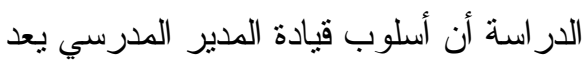

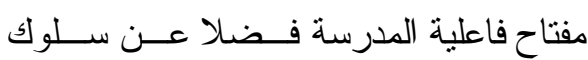

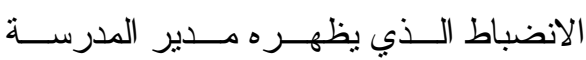

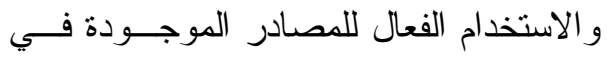


و انحر اف معياري( r., ·•) ودرجــة

• جاء مجال نقافة المهمة في المرتبـــة

$$
\text { ممارسة كبيرة. }
$$

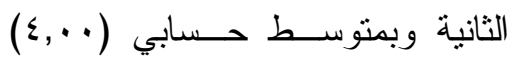

- عدم وجود فروق ذات دلالة إحـصـائية

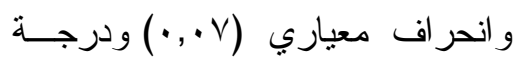

ممارسة كبيرة.

عند مستوى الدالة (0., •->а ) في درجة

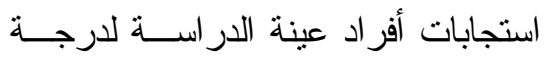

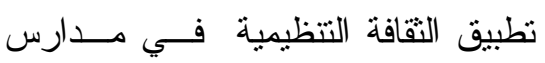

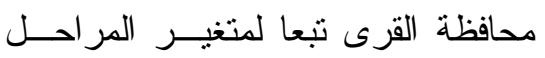

التعليمية

- وجود فروق ذات دلالة إحصائية عنـــ

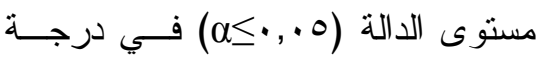

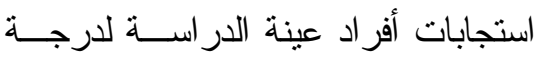

تطبيق الثقافة التتظيمية فـي مــــارس

محافظة القرى تبعـــا لمتغيـر ســنوات

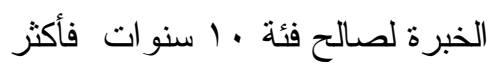

- عدم وجود فروق ذات دلالة إحـصائية

عند مستوى الدالة (0., •-بك) في درجة

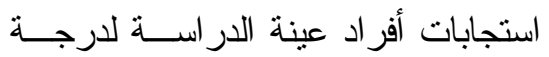

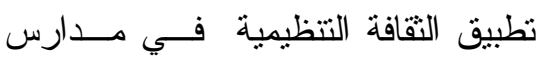

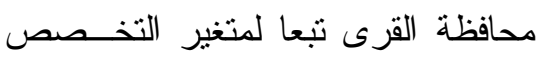

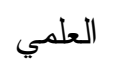

- عدم وجود فروق ذات دلالة إحـصائية

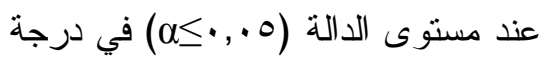

استجابات أفر اد عينة الدر اســـة لدرجــة فئة

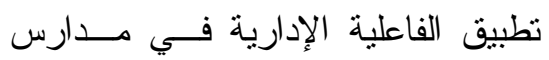

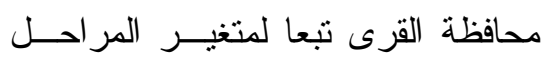

التعليمية

• جاء مجال ثقافة العطليات في المرتبــة

الثالثة وبمتوســ حس حسابي (r,90)

و انحر اف معياري (0., (·) ودرجــة

$$
\text { ممارسة كبيرة. }
$$

• جاء مجال ثقافة السياسات الإداريــة

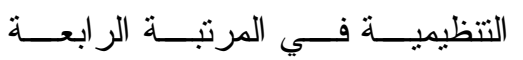

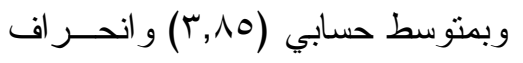

معياري (V)

$$
\text { كبيرة. }
$$

- أظهرت نتائج الدر اسة أن مجــالات أداة

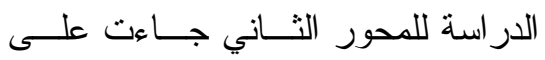

النحو الآتي

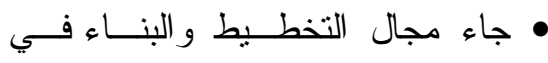

المرتبة الاولـى بمتوســـ حسـاءي

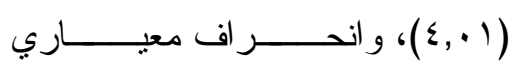

( ) , , • ) بدرجة ممارسة كبيرة.

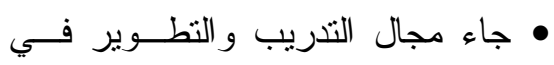

المرنبة الثانية ، وبمتوســـ حسـسابي

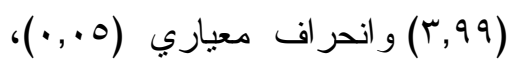

ودرجة ممارسة كبيرة.

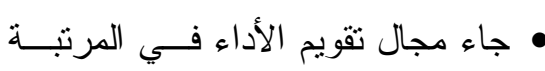

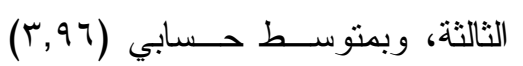


عقـــد دورات تدريبيـــة لتحــسين أداء المعلمين في الثقافة التتظيمية وعلاقتها بممارسة الفاعلية الإدارية هتظيم لقاءات ونـــدوات علميــة تعــالج

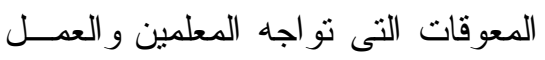

$$
\text { على ايجاد حلول لها. }
$$

تقديم دور ات تدريبية للمعلمين حول سبل

$$
\text { تطوير المهار ات المهنية. }
$$

ثالثاً: مقتزحات الدراسة

يقترح الباحـث إجـــــاء الارســـات

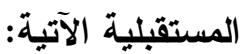
• المعوقات التي نواجه القيادات الاكاديمية في تتمية المعلمين مهنيا.

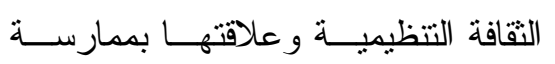
الفاعلية الإدارية للمعلمين دور التتمية المهنية للمعلمين في تحسين الاداء لديهم.

• اجر اء در اسة تتتاول الثقافــة التتظيميــة و علاقتها بالو لاء التتظيمي

قائمة المراجع

$$
\text { اولاً: المراجع العربية المراجع }
$$

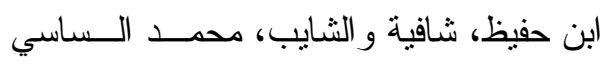

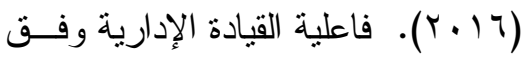

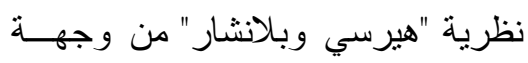
نظر الموظفين: در اسة ميدانية بجامعسـة ورقلــة. مجلــة العلــوم الإنــسانية
- وجود فروق ذات دلالة إحصائية عنــد

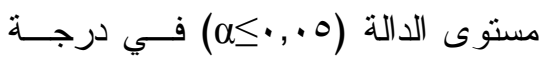

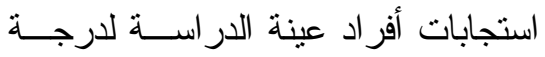

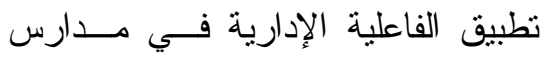

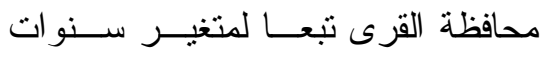

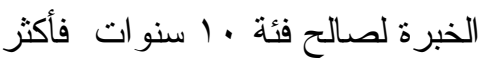
- عدم وجود فروق ذات دلالة إحـصائية عند مستوى الدالة (0., •• $\alpha)$ في درجة إسة

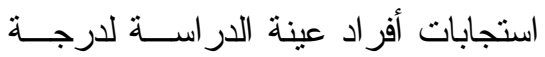

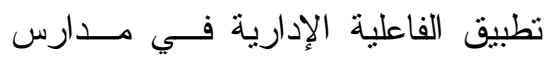
محافظة القرى تبعا لمتغير التخـصص التصلي

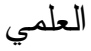

ثانياً: توصيات الدراسة

في ضوء النتائج التي توصلت إليها الاراسة فان الباحث يوصي بما يلي:

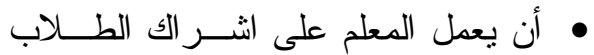
في باختيار الاستر اتيجيات التي تتاســـهر ونتشبع حاجاتهم. • ان تهتم القيادات الاكاديمية في المدارس بالتتمية المهنية للمعلمين بشكل اكثر مما لهادئ هو عليه. العمل علـى تــدريب المعلمــين علـى

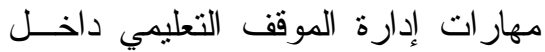
القاعات الدر اسية. • العمل على نتظم ورش عمل للتـدريب على إعداد البر امج و الخطط الدر اسية. 


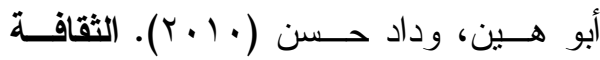

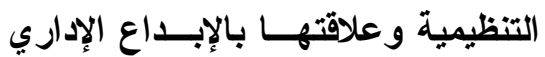

لــــى مــــيري المـــــارس الثانويــــة

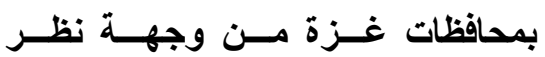

المعلمين. رسالة ماجستير غير منشورة، الجامعة الإسلامية بغزة، فلسطين.

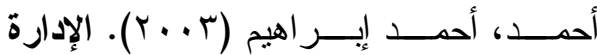

المدرســـية فـــي الألفيـــة الثالثـــة.

الإسكندرية: مكتبة المعارف الحديثة.

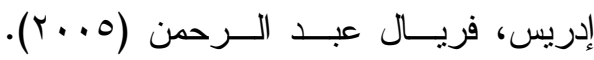

أنماط الثقافة التنظيمية السسائدة فـي تربي

إدارة المدارس الثانوية بمدينـــة مكـــة

المكرمة من وجهـــة نظـــر المعلمـين

و المعلمــات. رســالة ماجـستير غيــر

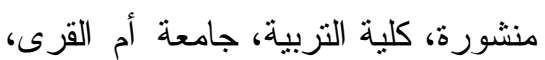

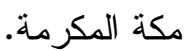

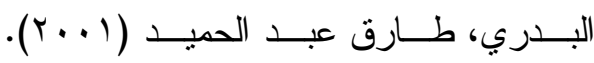

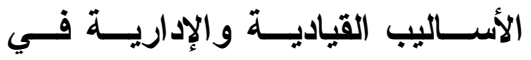

المؤسسات التعليمية. عمّان: دار الفكر

للطباعة و النشر و التوزيع.

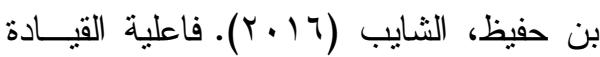

الإدارية وفق نظرية هيرسي وبلانـشـار

من وجهة نظـــر المــوظفين - دراســـة

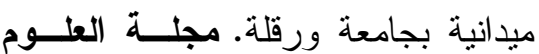

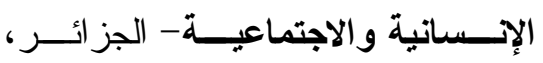

$.11 V-I T r_{6}(r T)$
و الاجتماعية - جامعة قاصدي مرباح -

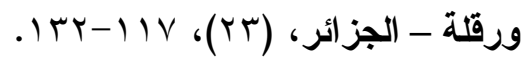

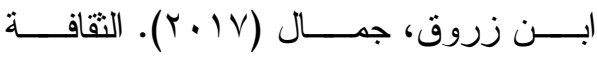

التنظيمية، الاتـــال التتظيهـي و إدارة

الأفـــــ اد داخل المؤسسة. مجلة الحقوق

و العلوم الإساتية- جامعة زيان عاشور

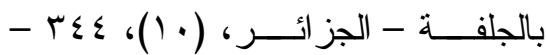

.rol

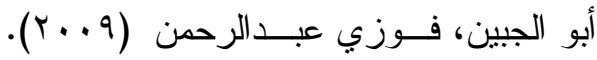

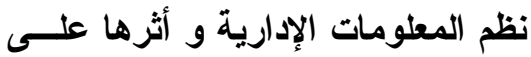

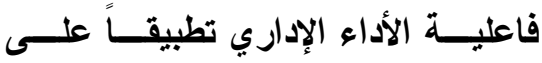

المؤسسات التعليمية بطر ابلس. رسالة

ماجستير غير منشورة، كليــة التزبيـــة،

جامعة أم درمان الإسلامية، السودان.

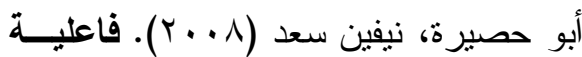

مدير المدرسة في وكالة الغوث الدولية بغزة من وجهة نظر المشرفين التربويين في ضوء معايير الجودة الشاملة. رسالة ماجستير غير منشورة، جامعة الأزهـــر فئر بغزة، فلسطين.

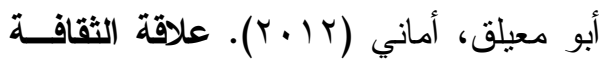

التنظيمية بالالتزام الوظيفي لدى معلمي المدارس الأساسية الحكومية بمحافظات غزة وسبل تطويرها. رسالة ماجستير غبر منشورة، الجامعة الإسلامية بغزة، فلسطين. 
العمل. طץ، عمان: دار الحامد للطباعة

$$
\text { و النشر و التوزيع }
$$

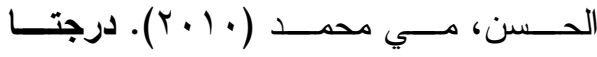

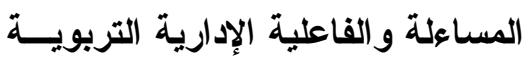

و العلاقة بينهما لدى مديري المـــارس

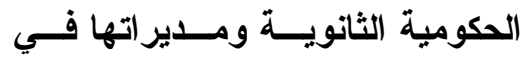

محافظات الضفة الغربية من وجهة نظر

العاملين في مديريات التربية والتعليم.

رسالة ماجستير غير منــشورة، كليــة

التزبية، جامعة النجاح، فلسطين.

حسن، نور عوض (10 • ب). درجة ممارسة

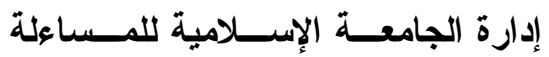

الإدارية وعلاقتها بدرجة فاعلية الأداء الإداري لموظفيها. رسالة ماجستير غير

منشورة، كلية التربية، الجامعة الإسلامية

$$
\text { بغزة. }
$$

حلو اني، ابتسام عبد الرحمن (9 . . ب). مسنـ أين يبدأ التغيير في ثقافة المنظمة. ورقة عمل مقدمة للمؤتمر الــدولي للتنميــة

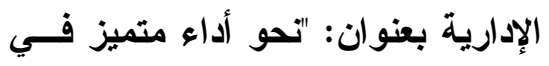
القطاع الحكومي"، الرياض، الفترة مسـن

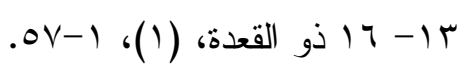

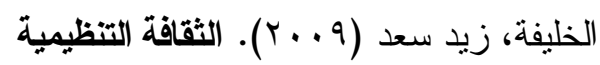
ودورها في رفع مستوى الأداء: دراسة مسحية على ضباط كلية القيادة والأركان للقوات المسـلحة الـسعودية. رســالة
التهامي، محمد جـودت (ع . . ب). تفعيـلـ

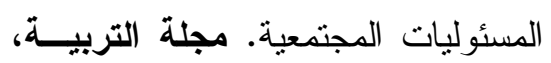

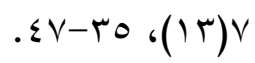

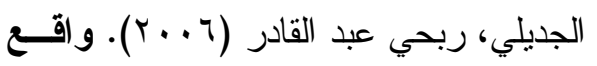

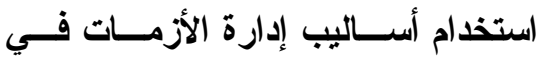
المستثفيات الحكومية الكبرى في قطاع غزة. رسالة ماجستير غير منشورة، قسم إدارة الأعمال، كلية التجارة، الجامعــة الإسلامية بغزة.

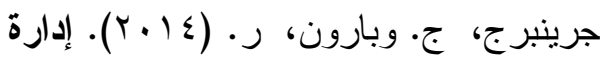
السلوك في المنظمات. طب، ترجمــة: رفاعي محمد، الرياض: دار المريخ.

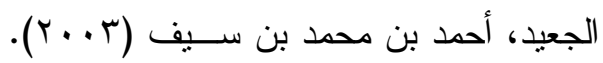

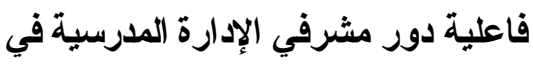
تطوير الكفايات الإدارية والفنية لمديري المدارس الابتدائية بمحافظة الطــائف. رسالة ماجستير غبر منـشورة، كليـة التربية، جامعة أم القرى. الحربي، قاسم بن عائــلـ (10 ـ ب). الإدارة المدرسية الفاعلة لمدرســة المسـتقبل

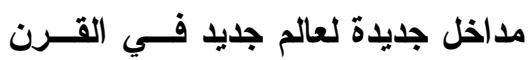

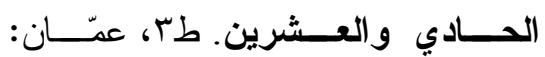
الجنادرية للنشر و التوزيع. حزيم، حسـن محمــود (ع ا •ب). تـصميم لمنظمة: الهيكل التظيمي وإجــراءات 


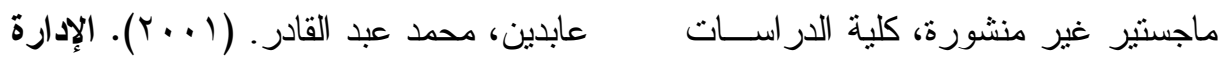

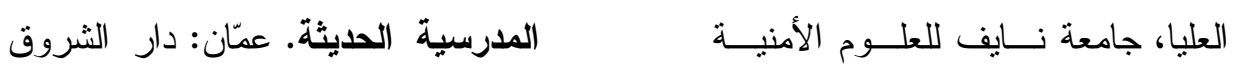

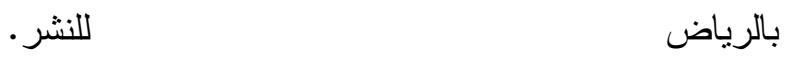

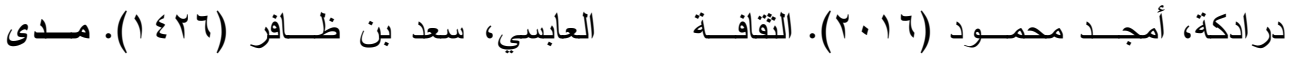

$$
\begin{aligned}
& \text { التنظيمية السائدة لاى مديري مــدارس فاعلية مدير المدرسة الثانوية في أداء }
\end{aligned}
$$

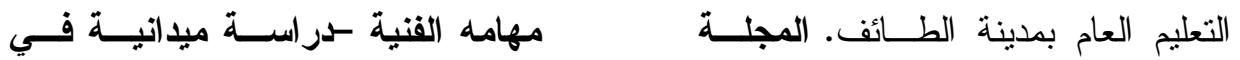

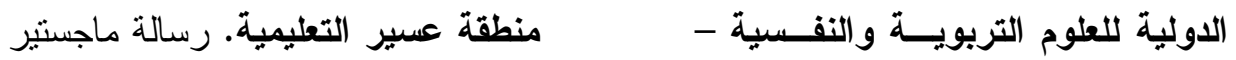

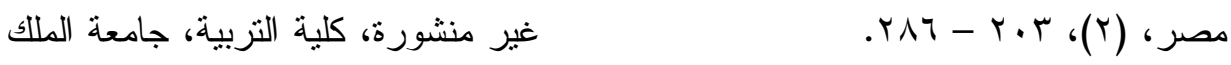

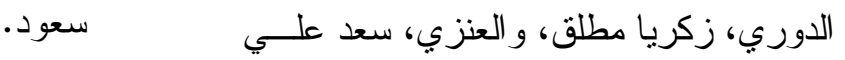

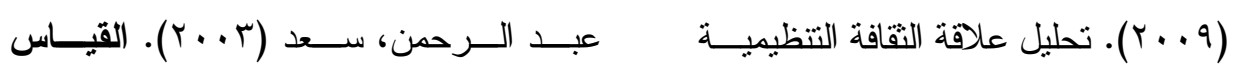

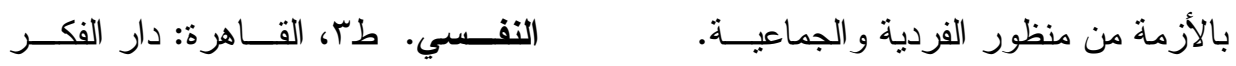

$$
\begin{aligned}
& \text { بحث مقدم للمؤتمر العلمي الثالث لكلية العربي. }
\end{aligned}
$$

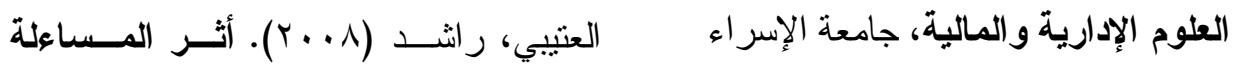

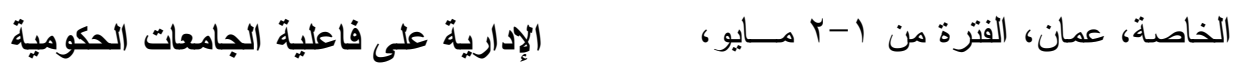

$$
\begin{aligned}
& \text { العربية السعودية. رسالة ماجستير غير }
\end{aligned}
$$

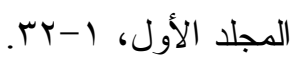

$$
\begin{aligned}
& \text { منشورة، جامعة مؤتة، الأردن. }
\end{aligned}
$$

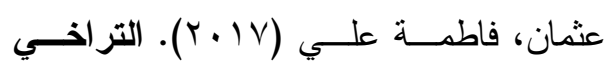

$$
\begin{aligned}
& \text { التنظيمي لدى مديري المدارس الثانوية }
\end{aligned}
$$

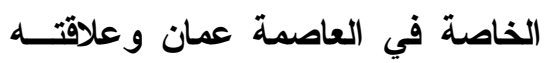

$$
\begin{aligned}
& \text { بالثقافة التظظيمية السائدة في مدارسهر } \\
& \text { من وجهة نظـر المعلمـين. رســالة } \\
& \text { ماجسنير غير منشورة، جامعة الـشرق } \\
& \text { الأوسط. }
\end{aligned}
$$

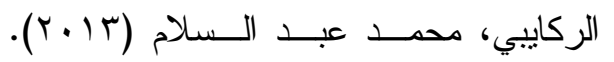

$$
\begin{aligned}
& \text { دراسة العلاقة بين الثقافــة التنظيميــة } \\
& \text { واستخدام الأساليب الحديثة للمحاســبة لئة }
\end{aligned}
$$

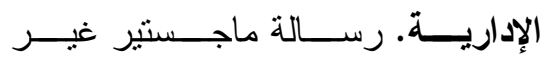

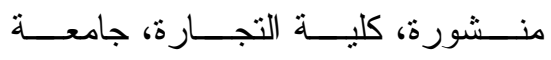

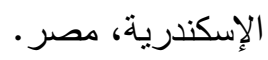

$$
\begin{aligned}
& \text { السكارنة، بلال (11) • (1). الإبـــاع الإداري. } \\
& \text { عمان: دار المسيرة للنشر و التوزيع. بالن. }
\end{aligned}
$$


المدارس الحكومية بمحافظــات غـزةة.

رسالة ماجستير غير منشورة، الجامعـة الإسلامية بغزة، فلسطين.

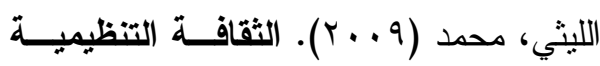

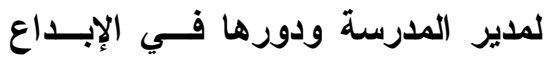
الإداري من وجهة نظر مديري التعلــيم الابتدائي بالعاصمة المقدســة. رســالة

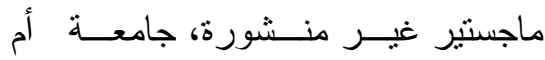
القرى، مكة المكرمة.

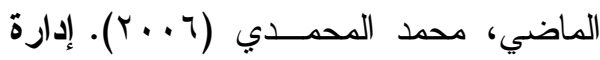
استراتيجية. القاهرة: جامعة القاهرة. المصري، جميل عزت (0. . ب ب). الحاجــات الادارية وفاعلية الأداء لعمداء الكليات ورؤساء الأقسام الادارية في الجامعات الاردنية الأهلية. رسالة دكتور اه غيــر منشورة، كلية الدر اسات العليا، الجامعــة

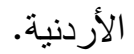

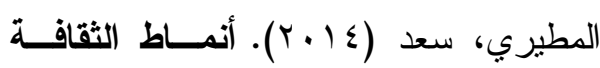
التظظيمية السائدة في مدارس التعلــيم العام في الهيئة الملكية بالجبيـلـل مـنـ مـن وجهة نظر المعلمين. رسالة ماجسـتير غير منشورة، كلية التربية، جامعة الملك فيصل، الإحساء.

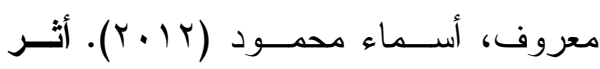
القيادة الخادمة على الثقافة التظيميــة بالتطبيق علــى المستــشفيات العامـــة
العلوم التربوية- جامعة القس المفتوحة،

$$
\text { 190-111، (乏) }
$$

عليان، ديمة عبد (Y (Y). الثقافة التظيمية

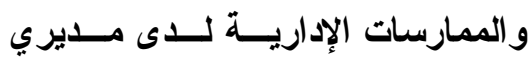
المدارس الحكومية والعلاقة بينهما من وجهة نظر المعلمـين فــي محــافظتي القــــس و"رام الله والبيـــرة". رســـالة ماجستير غير منشورة، كلية الدراســات العليا، جامعة النجاح، فلسطين.

الغامدي، عبد الله مغرم (ع . ب؟). مخرجات التعليم الثانوي العـام ومهـدى تلبيتهـــا لمتطلبات سوق العمـلـل فـــي المملكـــة العربية الـسـعودية. المجلـــة العلميــة لجامعة الملك فيصل - العلوم الانسانية

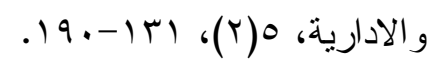

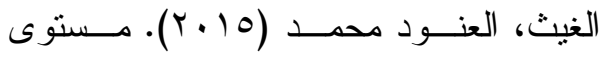
الثقافة التتظيمية لدى مدير ات المـــدارس

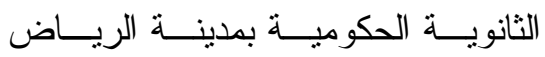

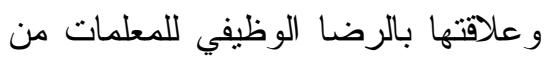
وجهة نظر مديرات المدارس ومعلماتها. مجلة الزرقــاء للبحــوث و والدراســـات

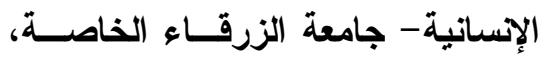

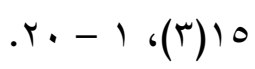
قرموط، عماد عبد الرحمن (10 • ب). درجة

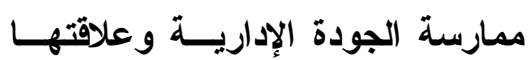
بفاعلية الأداء الوظيفي لــــ مــديري 
بالمملكة العربية الـسعودية. رسـالة

ماجستير غير منشورة، كليــة التزبيــة، جامعة أم القرى، مكة المكرمة.

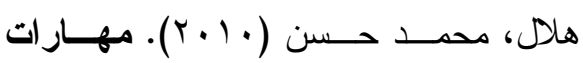

مقاومة ومواجهة الفساد :دور الثفافية

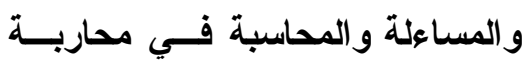

الفساد. مصر الجديدة: مركز تطــــير

الأداء و التتمية.

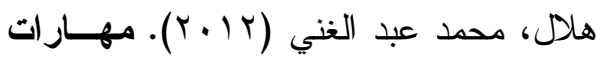

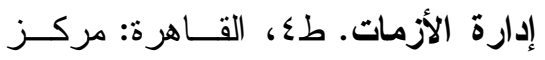

$$
\text { تطوير الأداء و التتمية. }
$$

ثانياً: المراجع الأجنبية:

Beverage, Layton Hubert (2003).

Inhibiting Factors to

Effectiveness and Adaptability

of New Superintendent in

Virginia. Dissertation abstracts

International.A64/01, P.31.

DeStefano, M. (2003). School

effectiveness, the role of the

principal in a leading public

secondary school in Santa $\mathrm{Fe}$

province,

Dissertation

Argentina.

International.AAT3091243.
و المركزية التابعـة لـــوزارة الــصحة

بمحافظة الاقهلية. رسالة ماجستير غير

منشورة، قـسم إدارة الأعمــال، كليــة

التجارة، جامعة المنصورة.

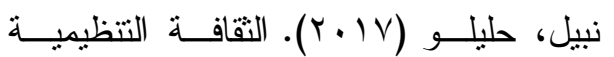

و الإبداع الإداري : أية علاقة ؟ : در اسة

ميدانية بغرفة الصناعة التقليدية بسكرة.

مجلة آفاق للعلوم- جامعة زيان عاشور

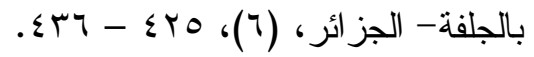

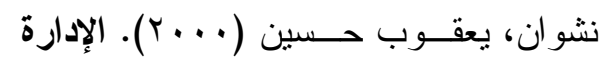

و الإثر اف التربوي. أريد: دار الفرقــان

للنشر و التوزيع.

نشوان، يعقوب حسين ونشوان، جميل عدــر

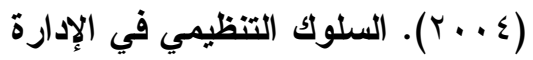

والإثر اف التربوي. ط(؟)، عمّان: دار

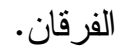

النويري، عبير ماجد (7 ا ـ r). درجة توافر

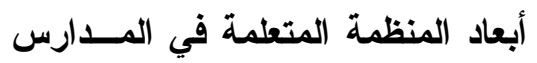

الثانوية بمحافظات غزة وعلاقتها بأتماط

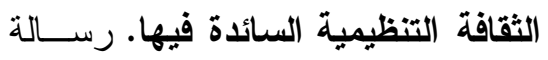

ماجسـتير غيـــر منــشورة، الجامعـــة

الإسلامية بغزة، فلسطين.

هديه، سعيد علـي (T) • (Y). آليـات بنــاء

الثقافة التظيمية الداعمة لتطبيق إدارة

الجودة الشاملة وتصور مقترح لبنائها

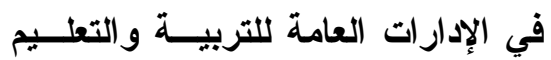


Freddy, A. (2014). Organizational Culture, Transformational Leadership, Work Engagement and Teacher's Performance: Test of a Model. International Journal of Education and Research, 2(1), 1-14.

Mutmainah, S. (2013). Organizational Culture, Leadership Style Influence on Organizational Commitment and Performance of Teachers. International Journal of Business and Behavioral Science, 3(10), 54-65.
Davis, Gerald F.\& Christopher Marquis (2005). Prospects for Organization Theory in the Early Twenty-First Century: Institutional; Fields and Mechanisms. Organization Science, 16(4), 332-343.

Efanga, S. \& Ifejiagwa, C. (2014). Influence of Organizational Culture on Performance Management Practices in Secondary Schools in Akwa Ibom State, Nigeria. International Journal of Humanities and Social Science, 4(4), 300-304. 